Historic, Archive Document

Do not assume content reflects current scientific knowledge, policies, or practices. 



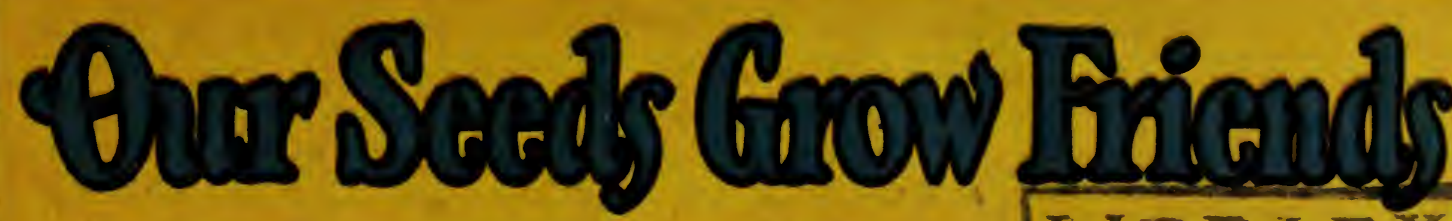
1928

L I BRA F Y rescrarrma?

$\star$ FEB $25192 \varepsilon \star$

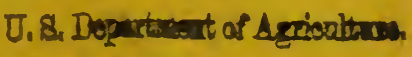

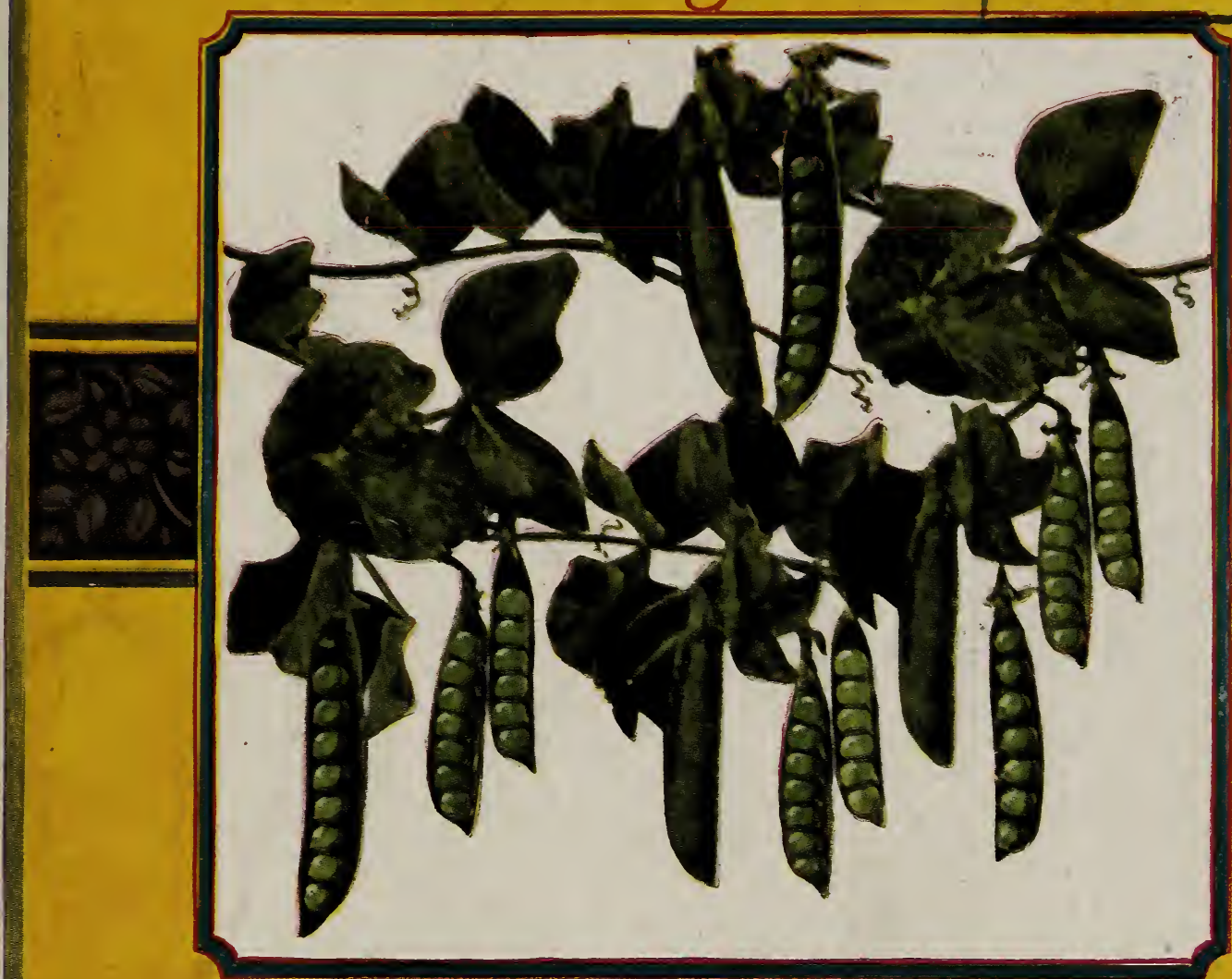

Our Laxtonian Pea

Order from your local dealer

\section{Or direct from}

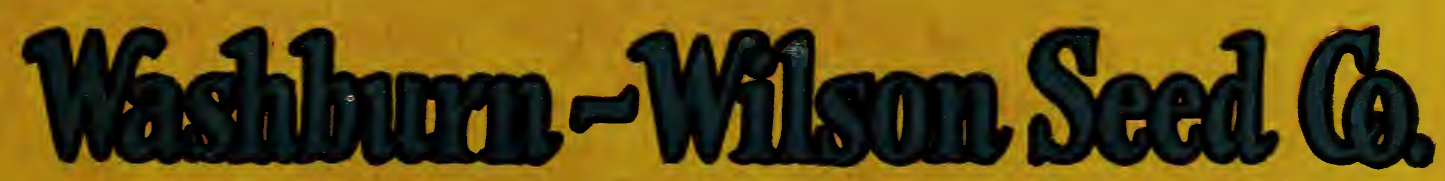
Moscow, Idaho 


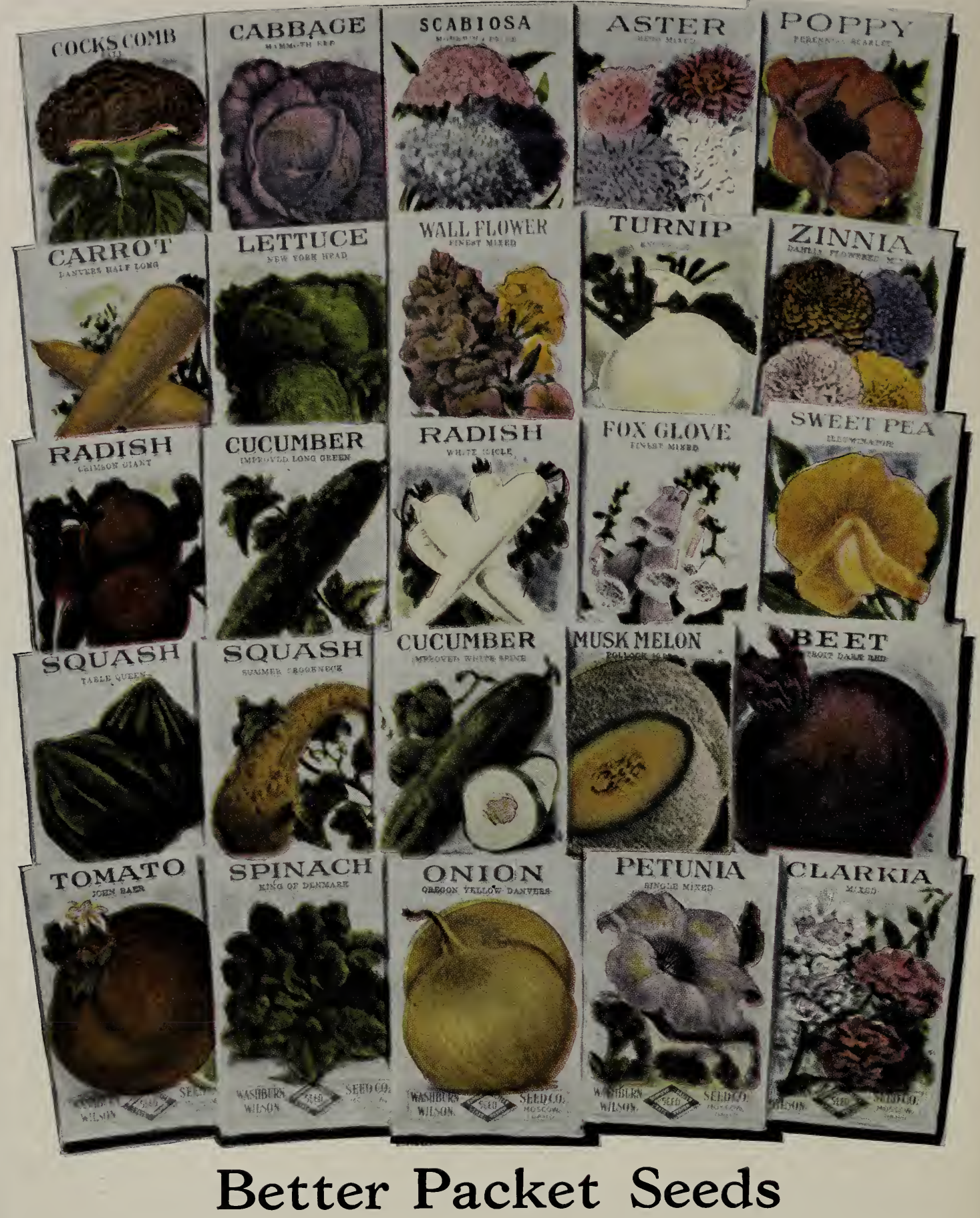

Our packets and cartons are put up for the gardener who uses only a small quantity of each variety. It is important that his planting should produce the maximum yield of high quality vegetables, if his garden.is a success.

Our packets are prepared from highly selected seed stocks, with a strong vitality, and if given favorable growing conditions, will give you excellent returns. It is not the size of the packet or the lithograph that makes the crop, but The Seed Inside the Packet that counts.

Your local dealer can supply you with a complete line of our vegetable, flower, and lawn grass packets. Ask him for our packets for planting this season.

Prices Consistent With Quality Washburn-Wilson Seed Co., Moscow, Idaho 


\section{To Our Customers:-}

Many of you have made use of our service department established last season and we urge you to write us again this year, if we can be of help in solving your crop and garden problems.

A new seed farm of 190 acres has been added to our business during the past season, to permit the breeding and increase of new strains of peas, seed potatoes, and other seeds. This work is under the direct supervision of Mr. Kennard. We maintain our trial garden on this farm where all stocks of vegetable seeds are tested for trueness to type, adaptability, and yield.

We trust that it will be possible for many of you to visit us during the year, so that you may become better acquainted with our methods of seed production.

- Many of our prices have been reduced this season in line with market conditions, but our quality is of the same high standard as has been maintained during the past.

May we be of service to you again this year?

Very truly yours,

Washburn-Wilson Seed Co.

\section{Special Vegetable Collection-1928}

1 lb. Duke's Delight Peas.

$1 \mathrm{lb}$. Giant Stringless Beans

1 lb. Golden Bantam Corn

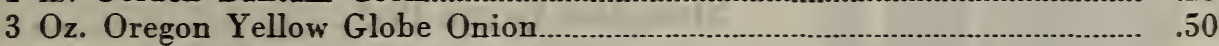

$3 \mathrm{Oz}$. Special New York Lettuce.................................................................... 50

2 Oz. Chantenav Carrot .............................................................................. .25

2 Oz. Crimson Giant Radish........................................................................ 25

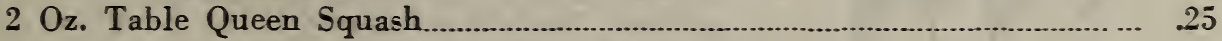

\section{Collection Price, \$2.25, Postpaid}

If you are interested in the following supplies or products. Write us and we will be pleased to quote sou: POILTRY scPPLIES: Feed Troughs, Fonntains and Feeders Mash Hopier, Leg Bands, etc., Sprajers, Drinking Fountaius, Disinfectants.

MISCELLANEOI'S FEEDS: Meat Yeal Yeat Scraps, Fish Meal, Oil Meal, Dried Buttermilk. Charcoal hardwood), Charcoal Bone, Eastern Oyster Shell, Grit (coarse, uredium fine), Granulated Bone (coarse, fine), Bone Meal.
BEE STPPLIEs: Cedar Hires, Hoffman Frames, Wax Foundation. Queen and Drone Traps, Hones Sections, Smokers. Bee Veils, etc.

FERTILIZERS: Garden and Lawn Fertilizer, Lettnce Fertilizer, Gypsum or Landplaster, Sreamed Bone Meal. Sheep Guano, etc. Nitrate of Soda, Sulphate of Ammonia, Superphosphate, Potash.

Refer to page 31 For Instructions Concerning Orders and shipment. 


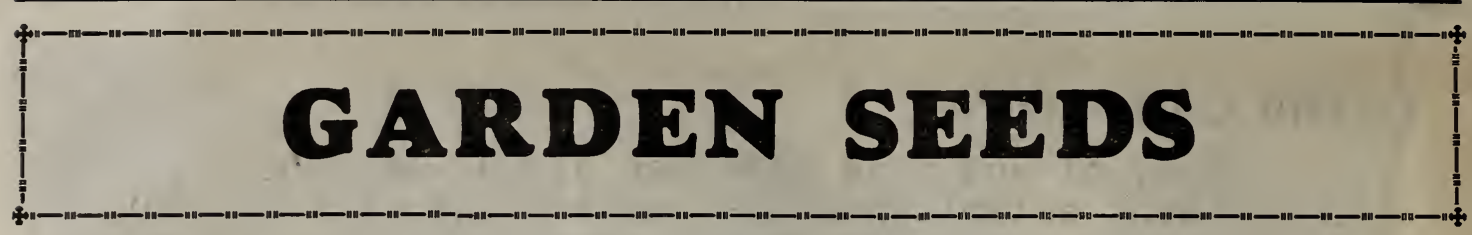

\section{Asparagus}

One ounce of seed will produce 300 or more plants.

CULTURE-It will require two to three seasons to produce a marketable crop of asparagus from seed, but this method is often superior to root planting as better plants can be selected for the permanent bed. Plant the sced in rows 12 to 14 inches apart, thinning the plants to 4 inches and allow to grow until the second season. Transplant to the permaluent bed with rows wide enough apart to permit cultivation. Fertilize heavily with well rotted manure.

MARTHA WASHINGTON-Our strain of this variety was selected for quality and resistance to rust. The stalks are white, of excellent flavor.

PALMETTO-While this variety is an old standard, it is still widely used. The stalks are greenish in color and the quality good.

\section{Postpaid Prices}

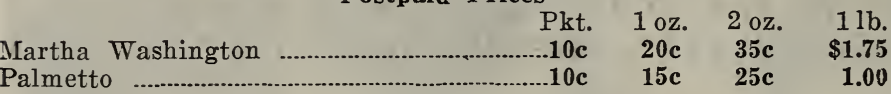

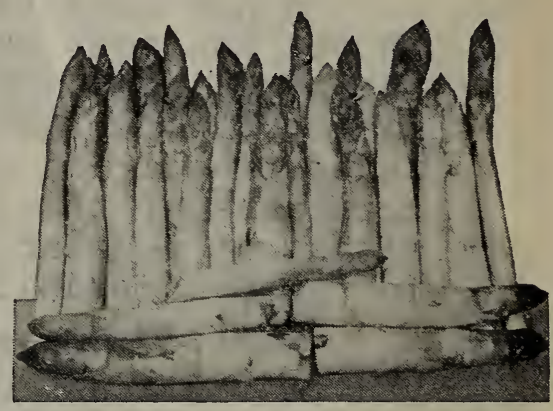

Martha ${ }^{\circ}$ Washington Asparagus

\section{Beans}

One pound will plant fifty feet of drill

CULTURE-Plant in warm, loamy soil at the beginning of settled warm weather in spring and at intervals for succession until August. Rows may be made two feet apart, and the beans planted a few inches apart in the drills, or three or four beans in hills six to eight inches apart. Cultivate and hoe frequently, always, howerer, when the vines are perfectly dry.

\section{Green Pod Bush Varieties}

GIANT STRINGLESS-While this variety is similar to Stringless Green Pod it is more productive and the pods are larger. You should grow this variety in comparison with other bush beans to appreciate it.

EARLY RED VALENTINE-This green pod bean is very early and produces pods of fine quality. It should be grown where moisture is limited.

EARLY REFUGEE-A popular variety with the shipper and home canncr. The pods are medium in size and of fine quality for canning.

EARLY SIX WEEKS-One of the earliest varieties for tho home gardener if harvested when the pods are small as the quality is very good. A very productive variety for the early home garden.

Stringless Green Pod This is the favorite bean with most growers because it is well pod.

REFUGEE OR 1000 TO 1 -We recommend this variety for a late crop as it can be sown at the same time as early maturing varieties. The pods are slender, brittle and of fine quality.

DWARF HORTICULTURAL-This bean is known as Bird's Egg. The seeds are large, round and marked with light red blotches. It is especially fine for use as a dry bean, producing a rich flavor for baking or cooking.

\section{WAX PODDED BUSH VARIETIES}

GOLDEN WAX-One of the best known Wax Pod varieties for early use. The pods are of medium size, very stout, fleshy and of good quality.

PROLIFIC BLACK WAX-The pods of this varjety are larger than those of the Pencil Pod Black Wax. It is one of the old standard varieties for the home garden.

PENCIL POD BLACK WAX-The pods of this variety are very slender and are in demand by the market garden trade. They are free of strings and are of rich flavor.

DAVIS WHITE WAX-This bean is somewhat later in maturing than the Golden Wax but is very productive. The pods are uniform and large, clear yellow and fleshy.

$\begin{array}{llll} & \text { Postpaid Prices } & \\ \text { Cartons } 1 / 2 \text { lb. } & 1 \text { lb. } & 5 \text { lbs. } 10 \text { lbs. } \\ \text { All Bush Beans...........15c 20c } & 30 \mathrm{c} & \$ 1.25 & \$ 2.25\end{array}$




\section{Pole and Climbing Beans}

\section{GREEN AND WAX POD VARIETIES}

KENTUCKY WONDER-We consider this rariety the most dependable for rield and of good quality. It is in demand for the canning trade and for home use. The pods are large, of good flaror and quite free of strings.

WHITE CREASEBACh-An excellent bean for snap purposes. It is rery hards and medium early in maturing.

LAZY WIFE-A bean with large oval seeds of pure white color. It is suitable for green beans as well as for use as a dry bean.

KENTUCKY WONDER WAX-A rariety similar to the green pod Kentucky Wonder in habits of growth, but has bright rellow pods.

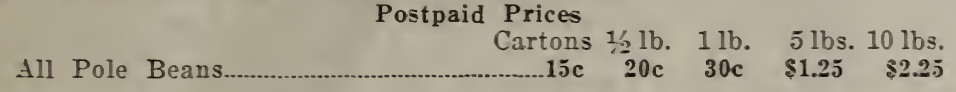

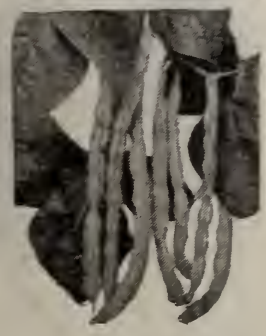

Kentucky Wonder

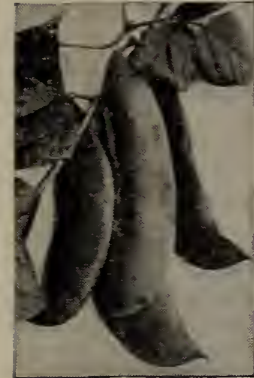

Bush Lima

\section{Lima Beans}

IMPROVED BLRPEE BLSH-A large-seeded dwarf bush, rers productire but some. what later than the Henderson Bush.

HENDERSON BLSH-This rariety is recommended where the season is short. The seeds are small but highly flarored.

POLE LIMA-This large-seeded rariety produces well but must be trained to a support. It is later in maturity than the bush rarieties.

\section{Postpaid Prices}

All Lima Beans

Cartons 1/2 lb. $1 \mathrm{lb}$. 5 lbs. $10 \mathrm{lbs}$ $\begin{array}{llll}15 \mathrm{c} & 20 \mathrm{c} & 35 \mathrm{c} & \$ 1.50 \quad \$ 2.60\end{array}$

\section{Beets}

One ounce will som 50 feet of drill; 5 to 6 pounds for an acre.

CCLTCRE-For early table beets, have drills 16 to 30 inches apart, and sow the seed about one inch deep, as early as the gromnd can be put in good shape. Gire thorough and clean cultiration, and thin the plants to stand $t$ inches apart in the rows. For succession sow at interrals until middle of July. For the earliest sowing a light dressing of nitrate of soda; say 100 lbs. per acre, will work wonders.

Table beets should be grown in erers garden as thes are produced with little effort and supply the table with greens as well as excellent roots.

\section{Table Varieties}

EARLY WONDER-A selection of Crosby's Egyptian haring a flat shaped root, uni. formly dark red in color. A popular rariety for market gardeners.

EARLY BLOOD TURNIP-This beet is somewhat globe shaped, and flattened. The

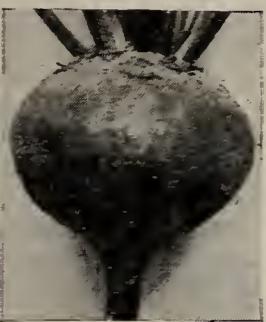

Early Egsptian color is bright red and flesh of fine texture.

DETROIT DARK RED-A medium sized globe shaped rariety of early maturity. A farorite for canning or slicing.

EXTRA EARLY EGYPTIAY-This early maturing rariety produces a small top. The roots are distinctirely flattened, the flesh dark in color with dis- tinct zones of lighter red. A desirable rariety for early fall use.

ECLIPSE-A conical shaped rariety of bright red color. The flesh is zoned with pinkish-white lasers. Postpaid Prices

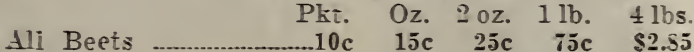

\section{Stock Beets and Mangels}

A small acreage of stock beets should be planted on erery farm for winter feed. They are valuable for Dairy Cows. Sheep and Poultry. It requires about 4 lbs. of seed per acre, seeding as early as the ground can be prepared in the spring.

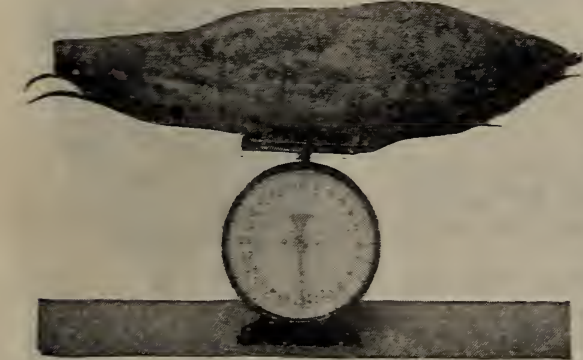

Improred Yammoth Long Red
DANISH SLUDSTRUP-The roots of this rariety are long, reddish rellow in color and growing more than half abore the ground.

GIANT INTERMEDIATE-This rariety is similar to Danish Sludstrup and rery popular Ior stock feed.

GOLDEN TANKARD-A choice mangel with a eslindrical shaped root of deep orange yellow skin. A rariety of rich flaror and high sugar content.

IMPROVED LONG MAMMOTH LONG RED-The roots of this variets are light red in color growing well abore the ground. A farorite with many gromers.

GIANT HALF SUGAR ROSE-One of the most popular mangels; rose colored skin and white flesh. A high vielding rariety of excellent feeding ralue.

\section{Postpaid Prices}

1 oz. 3 oz. $1 \mathrm{lb}, 5 \mathrm{lbs}$ All Mangels 10 c 25c 75 c $\$ 3.00$ 


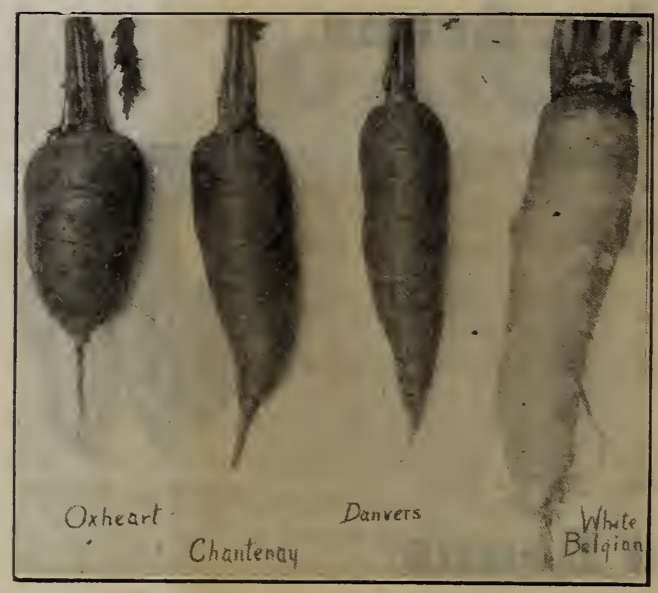

Grown From Our Own Stocks

\section{Carrots}

One ounce will sow 100 feet of drill; 3 to 4 pounds for an acre CULTURE-Carrots do best in warm, deep, rather light and fertile soil that is well supplied with humus, or on strong loam having been in clover and broken the year before. For the earliest crop sow seed of the early short-rooted sorts in April or May in drills a foot apart and thin to 2 inches. For main crop, sow in May or June, or for succession even in July, using the longer rooted varieties. The rows for these may be 16 to 30 inches apart, and the plants thinned to 2,3 , or even 4 inches. To raise carrots for stock the rows may be made wide enough apart, say 2 to $2 \frac{1}{2}$ feet, to allow of cultivation by horsepower.

\section{Table Carrots}

DANVERS HALF LONG-A favorite with many home gardeners because of its yield and quality. The roots are tapering from the shoulder and of bright orange color.

CHANTENAY - We recommend this variety because the roots are tapering and stumped at the base making them more easily harvested. They are equal in yield but consider this variety superior to the Danvers.

OXHEART-A short stump rooted variety adapted to heavy soil. A favorite with many because they do not break off in harvest.

\section{Stock Carrots}

LONG ORANGE-This carrot grows to a large size, the entire root growing under the surface of the. soil. An excellent variety for stock feeding.

WHITE BELGIAN-As some growers prefer a white carrot we offer this variety of white carrot as an excellent one for stock feed.

\section{Celery}

One ounce will produce 5,000 plants

GOLDEN SELF-BLANCHING-A very early variety, requiring little labor to blanch. The plants are stocky, medium in size, with golden heart and light yellowish green outer leaves. Very tender and crisp, in demand on the market.

WHITE PLUME-An early main crop variety, suitable for fall and winter use. The leaves are bright green with light tips, the inner leaves turning white as the plant matures.

\section{Postpaid Prices}

All Celery

\section{Cauliflower}

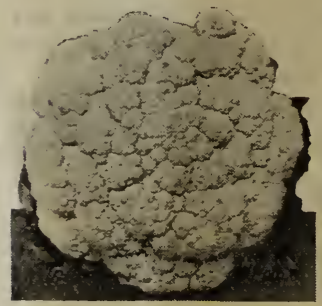

Early Snowball
One ounce will produce 3,000 plants.

CULTURE-For early cauliflower sow seed in hot bed and transplant to cold frame 2 inches each way. Set plants in permanent garden same as cabbage. To blanch draw leaves about the head and tie with tape.

Pkt. $1 \mathrm{oz}$. 10c 50c

EARLY SNOWBALL-Our strain of snowball is especially selected for uniformity, early maturity and quality. The heads are large, solid and suitable for early market use.

DANISH DRY WEATHER-While this variety is somewhat later than Snowball it is quite resistant to drought. It is equal in quality and yield.

All Cauliflower

$$
\text { Postpaid Prices }
$$

Pkt. $10 \mathrm{c}$

$1 / 2$ oz.

\section{Swiss Chard}

Every home garden should contain a few rows of this leafy vegetable. The top only is suitable for food, using the tender leafy portion for greens. The plants grow rapidly and produce a good crop early in the spring before other leafy crops are ready. Poultrymen grow this crop for green feed for use during the early spring for stock not having access to open range.

LUCULLUS-This leafy variety is very upright in habit of growth with large crumpled, curly leaves; very desirable for greens.

\section{Postpaid Prices}

All Swiss Chard.

Pkt. 1 oz. 2 oz. $1 \mathrm{lb}$. 10c 15c 25c 85c

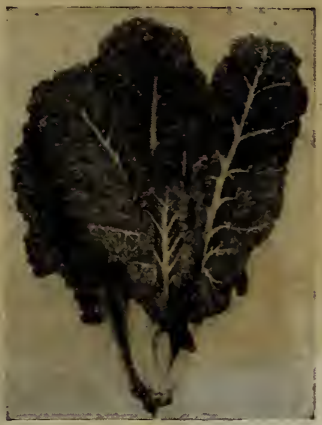

Swiss Chard 


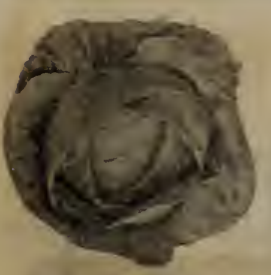

Early Flat Duteh

\section{Cabbage}

Sow one unnce for 2.000 plants; four to six ounces for one acre.

CULTURE-For plants of the earliest sorts, sow seed in January or February mnder glass and transplant into lats 2 inches apart. Set out as early as segson will permit, spacing the plants 24 inches apart in the row and rows 3 feet to permit cultiration.

For late plants, the seed mas be sown as late as June, planting in the permanent location. These late plants will make the greater part of their gromth in the esrly fall.

EARLY JERSEY WAKEFIELD_An excellent rariety for early market, producing Early Jersey Wakefield conical-shaped heads.

EARLY WINNIGSTADT-This early variety is similar to Jersey Wakefield, but the leares hare a peculiar trist at the top of the head. The heads are firm and of good quality.

GOLDEN ACRE-One of the best rarieties originally selected from Copenhagen Market. It is a round-hearled rariety, rery compact, maturing with Early Jersey Takefield.

COPENHAGEN MARKET-The heads of this variety are large. flattened and solid. It is superior for early market use.

EARLY FLAT DUTCH-Similar in type to the late flat type and selected for early maturity.

LATE FLAT DUTCH-One of the most popular rarietis for late summer or early fall use. The heads are large, round, flattened and very firm.

DANISH BALLHEAD-Our strain of Danish Ballhead produces rery large round heads of finest quality for winter use.

DANISH DARK RED-This cabbage has dark red leares and is desired for use in salads and for food decoration. The heads are large and solid, and late in maturing.
PE TSAI-(Chinese Cabbage) - A cabbage of loose head formation resembling Cos Lettuce. It has a cabbage-like flavor and is generally used in salads. Postpaid Prices

Pkt. $1 \mathrm{oz} .2 \mathrm{oz} .1 \mathrm{lb}$.

Early Jersey Wakefield...........10c 20c 35c \$2.00 Copenhagen Market …..............10 c 20c $35 \mathrm{c} \quad 2.00$ Early Winnigstadt ...................10 20 c 30 c 1.75 Early Flat Duteh ….......................... $20 c \quad 35 c \quad 2.00$ Golden Acre $\quad 10 c \quad 35 c \quad 50$ e 3.50

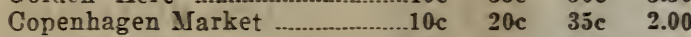
Late Flat Dutch …..................... 25c 40 c 2.50

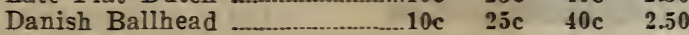
Danish Dark Red........................10c 25c 40 $\quad 2.50$ Pe Tsai ……............................ 35 c 65 c 4.00

\section{BRUSSELS SPROUTS}

A member of the cabbage family, producing a tall stalk, upon which are borne many small cabbage-like heads. A very tender and palatable regetable. The crop should be grown and handled like a late variety of cabbage.

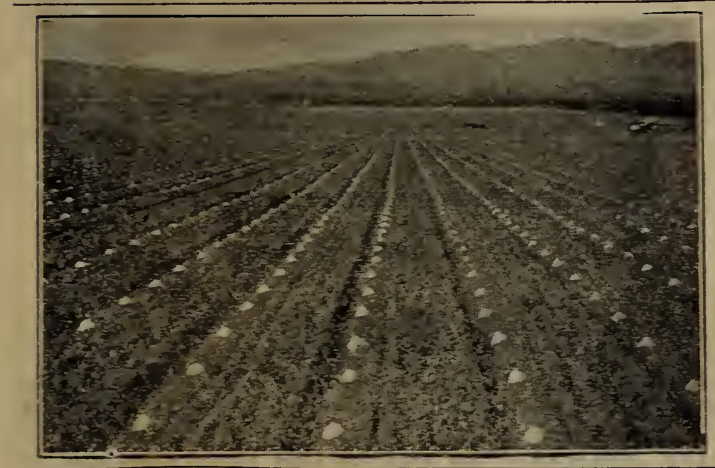

\section{Protect Plants for Profit}

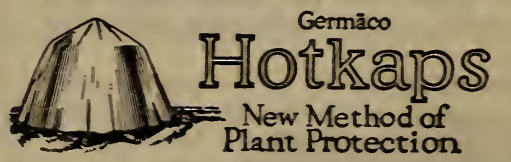

Eliminate Yost of the Risk in Growing Vegetables. rou extra dollars this season. They protect your tender plants from frost, wind, rain, hail, and insects. Plants grow faster and yield larger crops for early market. One man can set 3000 Hotkaps a day.

\section{Postpaid Prices}

1000 Hotkaps $\quad \mathbf{5 0 0 0}$ Hotkaps Hotkap Setter $\$ 11.75 \quad \$ 56.00 \quad \$ 2.60$

Write for large quantity prices, and special literatare.

\section{Cucumbers}

One ounce will plant fifty hills; two pounds will plant one acre

CCLTCRE-For very early cucumbers. sow April 1st, in a hotbed upon pieces of sod (grass side down), so that the 5 can be readily transplanted to the open ground, in rich 80 il, when danger of frost is orer, or protect by single window panes. For early use, plant if the weather has become settled and warm, in hills $t$ to 6 feet apart each way; thin out to four of the strongest plants to each hill, after all danger of insects is orer. Cucumbers should be gathered when large enough for use, whether required or not, if left to ripen, it destroys their producwhen la

BOSTON PICKLING-One of the late standard rarieties with medium short fruits, of best quality for pickling. It is rery early and productive.

DAVIS PERFECT- We recommend this rariety as one of the best general purpose eucumbers. It has a dark green fruit, slightly pointed towards the ends, of good size and excellent quality. A variety in demand on the commercial market.

EARLY CLUSTER-The fruits of this rariety are small in size with rery smooth skin. A choice rariety for pickling and rery early in maturity.

IMPROVED WHITE SPINE-One of the earliest of the spine rarieties, with large short fruits which are erisp and mild. Fine for slicing or piekling.

IMPROVED LONG GREEN-A very prolific medium late variety. The fruits are long and tapering. of dark green color. A choice rariety for a com. mercial market,

All Cucumbers

Postpaid Prices

Pkt. $10 \mathrm{z} .2 \mathrm{oz} .1 \mathrm{lb} .5 \mathrm{lbs}$ $10 \mathrm{c} \quad 15 \mathrm{c} \quad 25 \mathrm{c} \quad \$ 1.25 \quad \$ 6.00$

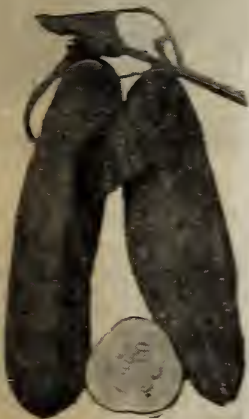

Long Green 


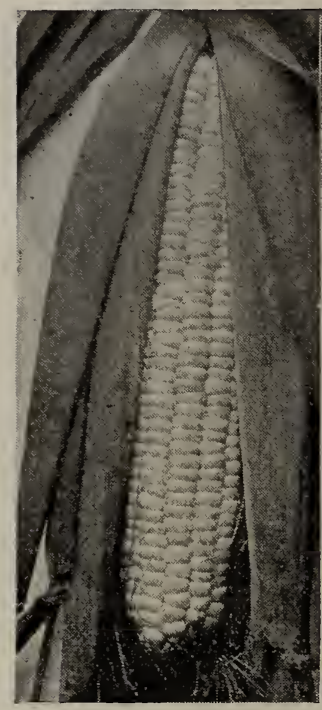

Early Evergreen

\section{Sweet Corn}

One pound will plant about 100 hills; eight lbs. per acre. CULTURE-While the sweet varieties mature earlier than field corn, it is well to take some risk in early planting. Plant as early as the ground can be worked into good condition, as a slight frost will do but little damage to the plants. The early corn can be forced to supply the early market and by successive planting, produce throughout the latter part of the summer. The seed should be planted in hills 3 feet apart each way, covering just deep enough to insure moisture for germination. If planted early, increase the number of grains to the hill and later thin to 3 or 4 plants to the hill.

It is advisable to sow several short rows in planting any variety to insure better fertilization and development of ears, rather than a single row across the garden. An early variety planted about every two weeks during the early part of the season will give a long harvest period. In case it is desired to plant the entire crop early, the proper choice of varieties will produce a successive crop.

PEEP 0' DAY - This variety is the earliest we offer. While the ears are small they are of excellent quality and several are produced upon a single stalk. The grains are white and very sweet.

WHITE COB CORY-Our strain of Cory is nearly as early as Peep O' Day and is preferred by market gardeners because of the large ears. A high yielding variety of good quality.

EARLY MINNESOTA-This standard variety is well known. The ears are larger than those of Cory and the grains are wider and very sweet and tender.

EARLY EVERGREEN-Our strain of early Evergreen is ready for market along with Golden Bantam. The ears are 7 to 8 inches in length, containing 10 to 12 rows of grain of good quality for market use.

BLACK MEXICAN-While Black Mexican is later in maturing than Golden Bantam it has a distinct quality and is very productive. The grains are white when in proper condition for market use, but change to a deep purple color when matured.

GOLDEN BANTAM-This corn is by far the most popular for home garden, and market use. It has a beautiful golden yellow color and excellent flavor. The ears are about 6 inches in length and generally 8 rowed.

STOWELL'S EVERGREEN-A medium late variety suitable for market or for stock feed. The stalks are large, leafy, and the ears large with good quality of grain.

COUNTRY GENTLEMAN-A very late variety suitable for a late crop in sections with a long growing season. The grains are produced in irregular pattern on the cob.

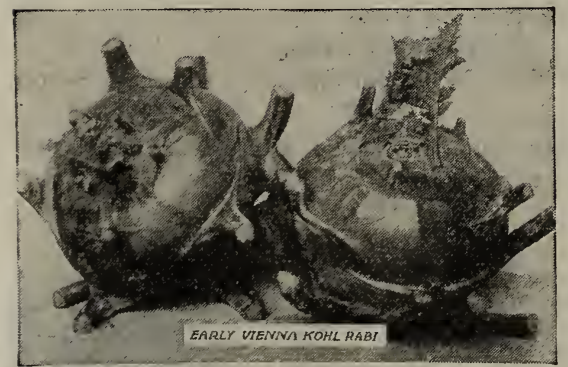
fected with worms as this turnip-like plant is not damaged to any extent.

EARLY WHITE VIENNA-The skin of this variety is light in color and the flesh white. It is very early in maturing and has a fine flaror.

PURPLE VIENNA--Similar to the White Vienna in maturing, but the skin is of a deep purplish color, the flesh white.

\section{Postpaid Prices}

All Kohl Rabi

Pkt. $1 \mathrm{oz} .2 \mathrm{oz} .1 \mathrm{lb}$. $10 \mathrm{c} 20 \mathrm{c} 35 \mathrm{c} \quad \$ 1.50$

\section{Leek}

One-half oz. will plant $100 \mathrm{ft}$. of row; $4 \mathrm{lbs}$. per acre. CULTURE-The Leek plant is closely related to onions and should be planted in the same manner. Sow the seed early in the spring on a very fine compacted seedbed, drilling the seed in rows just far enough apart to cultivate easily. Thin the plants to 8 inches in the row.
MUSSELBURG-A hardy variety with fan-shaped leaves of very dark green color, a choice variety for soups, ete.

\section{Postpaid Prices}

Pkt. 1 oz. 2 oz. $1 \mathrm{lb}$.

Musselburg ….......10 30 30 50c $\$ 3.00$

We spend considerable time each season in the irrigated as well as the non-irrigated sections, studying methods of crop production. Let us help you with your problems in growing garden and field crops. 


\section{Lettuce}

One-half ounce will plant $100 \mathrm{ft}$. of row; 3 lbs. per acre.

CULTURE-Lettuce may be sown as early in the spring as the soil can be prepared. It is hardy and will withsevere conditions. By sowing successive plantings of leaf and head varieties, the crop will produce throughout the season. During extremely hot and dry weather, some of the heading varieties may not head up well, so that leaf types will furnish a crop.

BLACK SIMPSON-A choice non-heading early variety with very crisp, light green leaves.

EARLY CURLED SIMPSON-The leaves of this variety are very curly, light green in color and very tender. A favorite for early garden use.

GRAND RAPIDS-This is a special variety for growth under glass, but it can also be grown outside. The leaves are long, golden green in color and very tender and crisp.

PRIZEHEAD-While this variety is called a head variety it produces very loose open heads and is much better for leaf pur poses. It is very early, and leaves are wavy, light green in color tinged with brown at the outer edge.

HANSON IIEAD-We recommend Hanson Head for the home garden as it is early and produces very solid heads for home use. The heads are lighter in color than the New York and do not stand shipment well.

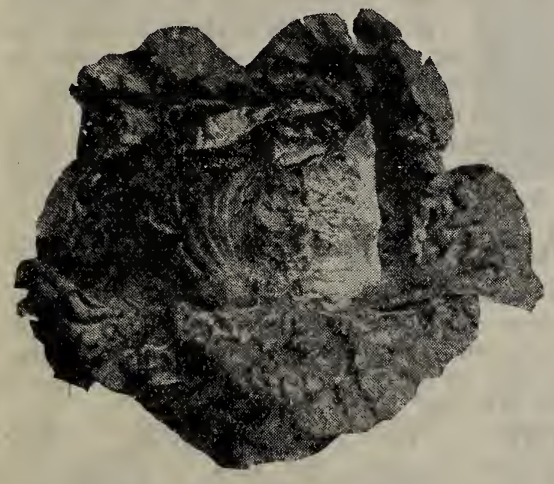

Prizehead
Postpaid Prices

Pkt. $1 \mathrm{oz} .3 \mathrm{oz} .1 \mathrm{lb} .5 \mathrm{lbs}$.

Black Simpson

Early Curled Simpson ..

$\begin{array}{rrrr}10 \mathrm{c} & 15 \mathrm{c} & 40 \mathrm{c} & \$ 1.00\end{array}$

Grand Rapids ...................................10c

Prizehead

Hanson Head............................................10c

Special New York.

Chicken Lettuce

Paris Cos
$15 \mathrm{c} \quad 40 \mathrm{c}$

$20 \mathrm{c} \quad 45 \mathrm{c}$

$15 \mathrm{c} \quad 40 \mathrm{c}$

$15 \mathrm{c} \quad 40 \mathrm{c}$

$25 \mathrm{c} 60 \mathrm{c}$

$15 \mathrm{c} \quad 40 \mathrm{c}$

$20 \mathrm{c} \quad 45 \mathrm{c}$
$1.00 \quad 4.50$

1.256 .00

$1.00 \quad 4.50$

$1.00 \quad 4.50$

$2.50 \quad 10.00$

$1.00 \quad 4.50$

1.256 .00

SPECIAL NEW YORK-We have had many favorable reports on as well as from home growers. Our stokk has been developed you breeding and selected for uniformity of type, quality and lettuce as it may mean the loss of your crop. Our stock comes diect from our growers in sealed bags and we furnish it to you in pound quantities or larger amounts under seal so that you are of the genuine special stock.

LETTUCE-A large coarse, rank growing lettuce depoultry, or planted in the poultry yard, the poultry allowed to

PARIS COS-A compact headed variety with large oval-shaped eaves.

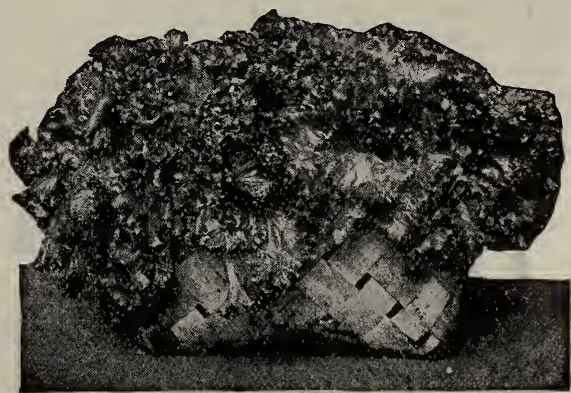

\section{Endive}

One oz. will plant $100 \mathrm{ft}$. row; 4 pounds per acre.

CULTURE-Endive makes a very fine salad, as the leaves are very tender, crisp, with a pleasant flavor. May be used as trimming for fancy dishes in same manner as lettuce. Plant the seed in the permanent row early in the spring and thin to space the plants about 12 inches in the row. After the plants form a compact leafy growth, pull the outer leaves up around those in the center and tie with cord to assist in bleaching out the center and ti
the inner leaves.

GREEN CURLED-The leaves of this variety are deep green in color with white ribs. When the plants are tied into a compact mass, the leaves blanch to a creamy white.

\section{Postpaid Prices}

Pkt. $1 \mathrm{oz} .2 \mathrm{oz} .1 \mathrm{lb}$ $\begin{array}{llll}\text { 10c } & 15 \mathrm{c} & 2 \mathrm{oz} . & 1 \mathrm{lb} \\ \mathbf{2 5 c} & \$ 1.50\end{array}$

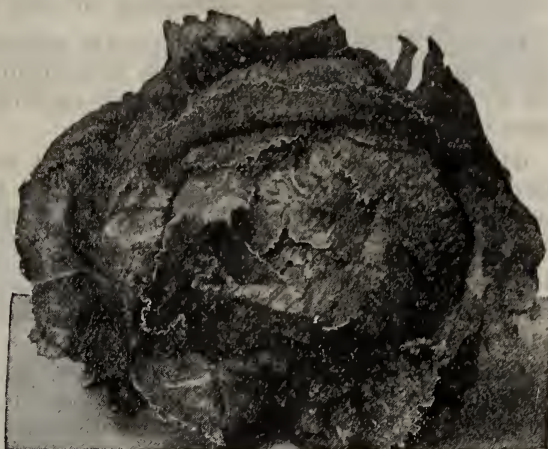

Special New York

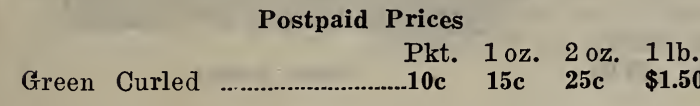




\section{Muskmelons}

One ounce will plant about 50 hills; two to three pounds in hills per acre.

CULTURE-Melons thrive best in a light, rich soil. Plant early in May, when the ground has become warm and dry, hills 5 to 6 feet apart each way for muskmelons, 8 to 10 feet for watermelons. Prerious to sowiln the seed, mix a shovelful of well rotted manure in each hill, and plant in each 12 to 15 seeds, after all danger of bugs is orer, thil out to three or four plants per hill. A few hills for early use mily be had by sowing on pieces of sod in a hotbed. and when warm enough transplant to open ground.

POLLOCK 10-25-The choice early salmon tint melon for commercial use. In outside appearance, it is similar to the Rockyford with fine netting and smooth sur. face.

GOLD LINED ROCKYFORD--Similar in type to the Rocksford hut the flesh is salmon tinted near the seed cavity. A main crop variety of delicate flavor.

EXTRA EARLY HACKENSACK - A green-fleshed melon of small size. The fruits are flattened with distinct ribs and netting. A choice early melon for home use.

BURREL'S GEM-Our Burrel's Gem has been selected for uniformity in size and deep flesh of fine quality. It is one of the best melons for commercial planting and stands shipment well.

ROCKYFORD or NETTED GEM-One of the old standard mid-season commercial melons. The fruits are oval to round and distinctly netted over the surface. The flesh is green in color with a delicious flavor.

OSAGE or MILLER'S CREAM-An egg-shaped variety of salmon colored fruit. While rather late in maturity, it is an ideal melon for home use.

HEARTS OF GOLD-It is well named, as the fruits are oval, with distinct ribs and netting over the surface. The flesh is a beautiful gold color, very thick, with a small seed cavity. A fine shipping melon and very productive.

BANANA-The banana melon tapers towards the ends and has a lemon yellowish colored skin. The flesh is pink, of delicious flavor, and a choice midseason variety for home use.

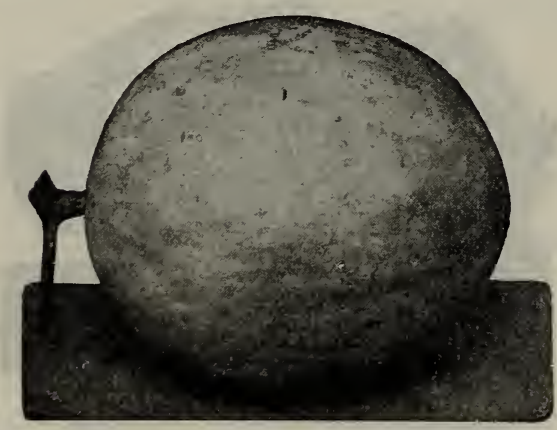

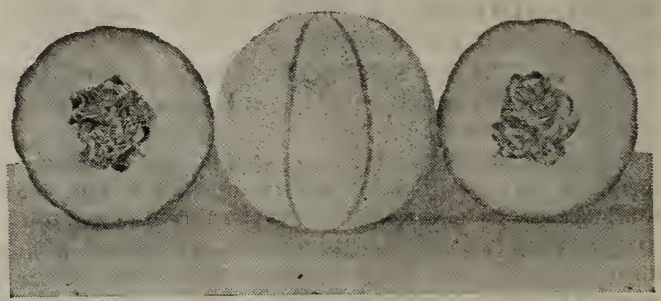

Hearts of Gold

HONEY BALL-Try this melon the coming season, you will be surprised. It was developed from crossing the Casaba with a cantaloupe. It has an indistinct netting over the surface, but is of greenish color. The flesh is more of the texture of the Casaba, but the flavor is delicious. It is mid-late in reaching market condition and is a good shipper.

IMPROVED YELLOW CANTALOUPE-A very old standard melon with deep ribs and of oblong shape. The flesh is pink and of spicy flavor. A good melon for the home garden.

\section{CASABAS AND HONEYDEWS}

GOLDEN BEAUTY-A globe-shaped Casaba with wrinkled skin. The fruit is of a golden yellow color when mature and the flesh is nearly white. It is rather late in maturity but keeps well in storage for late fall use.

HONEYDEW - The honeydew melon is also late and a good keeper. The skin is smooth, of creamy yellow color and the flesh light green and very sweet in flavor.

Honey Dew

\section{Egg Plant}

One ounce will furnish about 2,000 plants.

CULTURE-Start the plants under glass in hotbed and transplant to field after all danger of frost is over. Space the plant 24 inches in the row and rows wide enough to cultivate. Fertilize the soil with Fertilo row and rows wide enough to cultivate.
$(4-8-5)$ using about $500 \mathrm{lbs}$. per acre.

BLACK BEAUTY-The fruits of this variety are very dark in color and they are earlier than those of the New York Purple.

NEW YORK PURPLE-One of the main market garden varieties, with large oval fruits of deep purple color.

\section{Postpaid Prices}

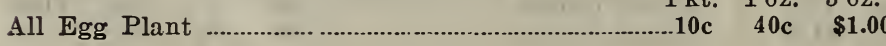

Pkt. $1 \mathrm{oz} .3 \mathrm{oz}$.

$.10 \mathrm{c} \quad 40 \mathrm{c} \quad \$ 1.00$

Pkt. $1 \mathrm{oz} .2 \mathrm{oz} .1 \mathrm{lb} .5 \mathrm{lbs}$.

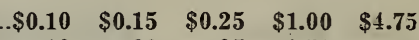

$\begin{array}{lllll}.10 & .20 & .35 & 1.50 & 6.25\end{array}$

$\begin{array}{lllll}.10 & .15 & .25 & 1.00 & 4.75\end{array}$

$\begin{array}{lllll}.10 & .20 & .35 & 1.50 & 6.25\end{array}$

$\begin{array}{lllll}.10 & .20 & .35 & 1.25 & 5.00\end{array}$

$\begin{array}{lllll}.10 & .20 & .35 & 1.25 & 5.00\end{array}$

$\begin{array}{lllll}.10 & .20 & .35 & 1.50 & 6.25\end{array}$

$\begin{array}{lllll}.10 & .20 & .25 & 1.25 & 5.00\end{array}$

$\begin{array}{lllll}.10 & .20 & .35 & 1.50 & 5.25\end{array}$

$\begin{array}{lllll}.10 & .20 & .35 & 1.25 & 5.00\end{array}$

$\begin{array}{lllll}.10 & .20 & .35 & 1.50 & 6.25\end{array}$

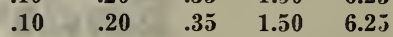




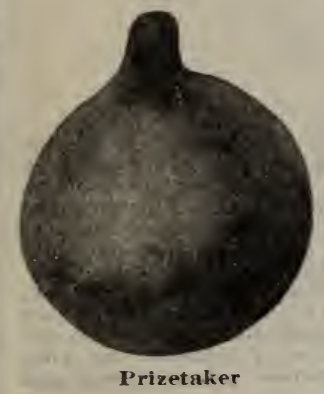

OREGON YELLOW GLOBEThis onion is similar to Yellow Globe Danver in type but have a milder flavor and a superior keeping quality. We recom. mend this stock for your commercial crop.

PRIZETAKER OR DENIAUnder irrigation this onion will attain a weight of $2 \frac{1}{2}$ lbs. It produces a yellow skin with pure white flesh of mild flavor. It is often sold as Spanish onion on the commercial market.

SOUTHPORT WHITE GLOBE -A globe shaped variety rather late in maturity, of fine appearance and good keeping qualities.

SOUTHPORT Y E L L O W GLOBE-These onions are light vellow in color with creamy white flesh. They are rather late but are excellent keepers.

YELLOW FLAT DANVERSIf you prefer a flat onion our stock of flat Danrers will meet your requirements.

YELLOW GLOBE DANVERS -One of the most popular rarieties known. It is in market demand, stands shipment well, and is very productive. Our seed is produced from highly bred stock.

\section{Onions}

he-half ounce will plant $100 \mathrm{ft}$. of row; four pounds per acre.

CULTLRE-Onions require a very finely prepared seed bed well enand with moisture near the surface. It is useless to plant a thin stand of weak plants will result. They should be planter] the seed.

USTRALIAN BROWN-An old favorite with a very dark A desirable keeper for winter use.

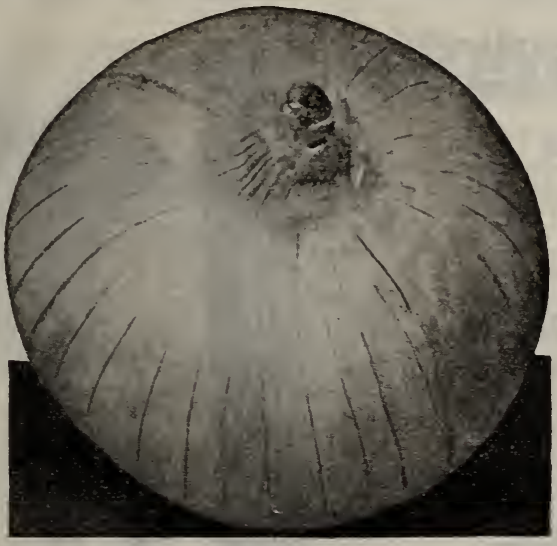

White Portugal or Silrer Skin

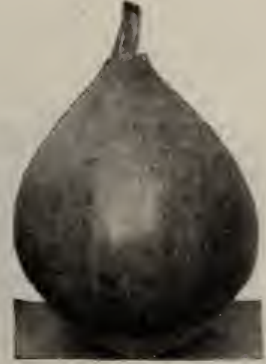

Oregon Yellow Globe

WHITE PORTUGAL OR SIL VERSKIN-A flat growing onion with silvery white skin and mild flaror. It can be used as an early green onion and for pickling.

SWEET SPANISH-One of the best commercial onions for irrigated sections where the growing season is long. It grows to a large size having a light yel. low skin, white flesh and of fine quality. We offer a special stock for the market garden trade.

GIANT GIBRALTAR-A com. mercial onion similar to the Sweet Spanish, very mild in flaror and a good keeper.

\section{Postpaid Prices}

\begin{tabular}{|c|c|c|c|c|}
\hline Australian Brown & $15 c$ & $40 c$ & $\$ 2.00$ & $\$ 9.75$ \\
\hline Oregon Yellow Globe. & $20 \mathrm{c}$ & $50 \mathrm{c}$ & 2.50 & 12. \\
\hline Red Wethersfield .... & $15 \mathrm{c}$ & $40 c$ & 2.00 & \\
\hline Prizetaker or Denia ......... & $25 c$ & $60 c$ & 3.00 & 14.50 \\
\hline Southport White Globe... & $25 c$ & $60 \mathrm{c}$ & 3.00 & 14. \\
\hline Southport Yellow Globe & $20 \mathrm{c}$ & $50 \mathrm{c}$ & 2.50 & [2. \\
\hline 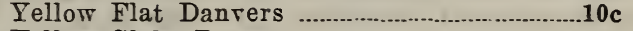 & $15 \mathrm{c}$ & 40c & 2.00 & 9.75 \\
\hline Yellow Globe Danvers & $15 c$ & $40 \mathrm{c}$ & 2.00 & \\
\hline - & $25 c$ & $60 \mathrm{c}$ & 3.00 & 4. \\
\hline iant Gibraltar & 25c & 60c & 3.00 & \\
\hline reet Spanish. & $30 c$ & $80 \mathrm{c}$ & 4.00 & 18. \\
\hline
\end{tabular}

\section{Bermuda Onion Plants}

Grow your onions the New Way, by planting small Bermuda plants. These small plants are produced in Texas by planting the seed early in the spring and as soon as the plants hare grown to height of 6 inches, the plants are pulled, the tops cut off and packed in bundles of 100 plants each.

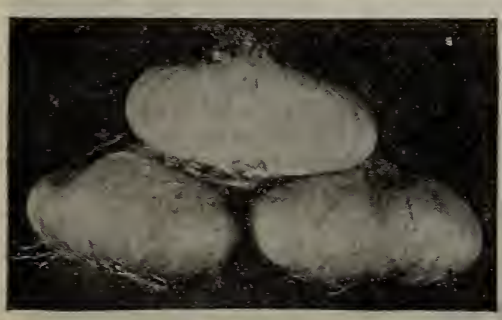

Bermuda Onions These plants are then sent through by fast express and are ready for planting. Many growers used them last season in place of seed and are more than satisfied. The plants were set out in April and onions weighing $11 / 4$ lbs. Were produced by August 1st, with only 2 inches of rain during the period. These Bermuda onions are large, flat in shape and of mildest flavor.

Price of Bermuda or Crystal Wax Plants, Delivered

200 plants 5.45

500 plants

1,000 plants 1.00

6,000 plants 9.00

For larger quantities, write for prices.

\section{ONION SETS}

YELLOW STRASSBURG-We have found this variety produces the best quality of sets as the onions are firm and uniform in size and free of dry wrinkled tops. These sets

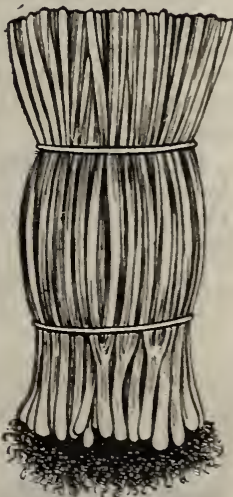

Young Bermudạ Plants will derelop into good onions for summer use if the seed stalks are pinched out while young. Postpaid Price; Lb. 25c; 2 lbs, 35c; 5 lbs. 80c; 10 lbs. $\$ 1.50$. 


\section{Garden Peas}

One pound will plant about fifty feet of row.

CULTURE-Peas of the extra early smooth class are the rery first thing to be planted in the garden in spring. The wrinkled sorts follow a little later, as they are not quite so hardy. Tall, late varieties need brush or other support. By selecting sorts that do not grow much over two feet high, the necessity of providing brush may be avolded. Judicious selection of varieties and planting frequently for succession will give a full supply of the choicest green peas almost during the entire season, with the possible exception of the hottest part of the summer. Open furrows three or four inches deep and three apart; scatter the seed peas into them and cover with hoe. Cultivate like corn or beans. The late tall sorts may be planted in double rows placing brush between for support.

The majority of the pea varieties we offer are grown in the ralouse section of eastern Washington and northern Idaho and are handled under the direct supervision of Mr. Ken nard, the President of our Company. We are pleased to give you the following suggestions as to choice of varieties as a result of our experience and observation: Do not plant home grown seed that has not been treated to kill the pea weevil because it is a source of infection for your neighbor and will result in a serious loss to yourself as well. All of our seed is fumigated before being cleaned and hand-picked.

\section{Varieties for the Market Garden}

Early Dwarf-Alaska, Laxtonian, American Wonder, Duke's Delight.

Mid-Early, Semi-Dwarf-Gradus, Premium Gem.

Late Dwarf-Dwarf Telephone, Yorkshire Hero, Stratagem.

Late-Tall-Tall Telephone.

\section{Varieties for the Home Garden}

Early Dwarf-Alaska, Laxtonian, American Wonder, Little Marvel.

Mid-Early-Gradus, Premium, Gem.

Late-Dwarf Telephone, Stratagem, Yorkshire Hero, Green Admiral, Horsford, Perfection, Tall Telephone.

DUKE'S DELIGHT-We offer this pea for your approval, as it is one of the finest early varieties we have grown. The plants are from 15 to 18 inches tall, the crop de. veloping with American Wonder, but requiring a longer period to reach full maturity. The pods are straight, large and blunt, varying from 3 to $3 \frac{1}{2}$ inches in length, from 7 to 9 seeds per pod. A fine variety for market and home use.

ALASKA-A very hardy variety for early planting. The seeds are small and of finest quality for canning and the entire crop is ready for harvest at the same time. Plants 2 feet in height.

LAXTONIAN (Blue Bantam)-Our stock produces very large pods curved at the end, averaging $3 \frac{1}{2}$ to $4 \frac{1}{2}$ inches in length. The plants are 15 to 17 inches tall, producing 4 or 5 pods each. One of the finest market garden varieties because of earliness and size of pod.

AMERICAN WONDER-The standard dwarf early variety for the home garden. The plants are bushy, producing a large number of pods, which are straight and blunt and well filled. Several pickings can be made in the home garden and the quality is excellent.

PREMIUM GEM-When sown at the same time as American Wonder, they are ready in succession. The plants are larger and produce a fine medium sized pod.

GRADUS-A second early variety growing to a height of 30 inches. The pods are large like the

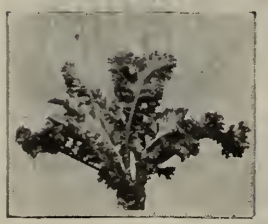

Mustard

Mustard

One ounce will plant $100 \mathrm{ft}$. of row; three pounds per acre.

CULTURE-Mustard may be sown early and in succession for continuous crop. Sow in rows on a fine but firm seedbed, thinning the plants to 4 inches in the rows. The tender leaves may be cut from the stalks and by careful harvest will reproduce for later crop. A fine succulent vegetable for greens and salad.

GIANT SOUTHERN CURLED-An excellent variety for greens. It makes a rapid growth of tender spicy leaves, retaining its crispness until nearly matured.

Postpaid Prices

Pkt. $1 \mathrm{oz} .3 \mathrm{oz} .1 \mathrm{lb}$. Mustard

10c 15c 25c $85 \mathrm{c}$ 


\section{Parsnips}

One-fourth ounce will plant $100 \mathrm{ft}$. of row; three pounds per acre.

CULTURE-Sow as early in the spring as the weather will permit, in drills 18 inches apart and 11/4 inches deep, in a rich deep soil; thin out 3 to 6 inches apart in rows. the quality of the roots is improved by leaving them in ground over winter for spring use. Secure enough in pits or cellars in the fall for immediate needs.

HOLLOW CROWN-A very popular one for market and home use. The roots are large, tender, crisp and rery sweet in flavor.

\section{Postpaid Prices}

Pkt. $1 \mathrm{oz} .2 \mathrm{oz} .1 \mathrm{lb}$.

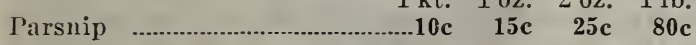

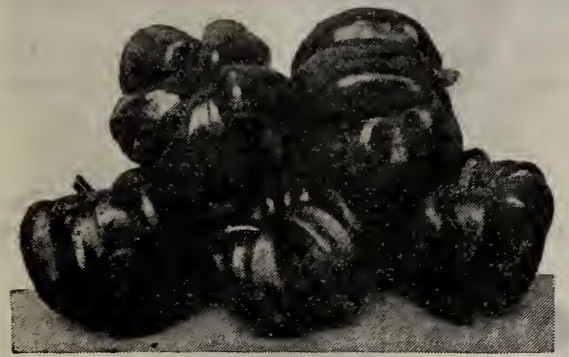

Ruby King

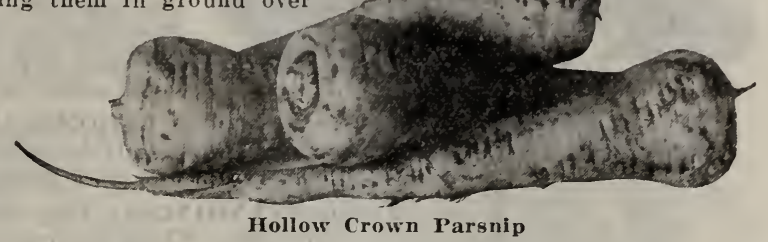

Peppers

One ounce will produce about 1,500 plants.

CULTURE-I'epper plants should be started in the hotbed or cola frame in early May, so as to be ready for transplanting by the time killing frost is over. Set out in clean soil, well fertilized, spacing the plants about 2 feet apart in the row.

LONG BELI or BULL NOSE-The fruits of this pepper are large, crimson in color and very mild in flavor. They mature early and are in demand for market use.

PIMENTO--A thick fleshed, heart shaped pepper of mild flavor. The fruits are long and slender and are much used for salads. This variety is rather late in maturity.

RUBY KING-A very satisfactory variety for home and market gardeners. The plants are early, dwarfed in habits of growth, the fruits large with thick flesh, very sweet and mild and of bright red color.

CHINESE GIANT-One of the largest varieties of peppers. The fruits are thick, bulky and of large dimension and medium early in maturity.

LONG RED CAYENNE-A hot, spicy pepper producing long. slender fruits which are twisted at the end. Medium late in maturity.

\section{Postpaid Prices}

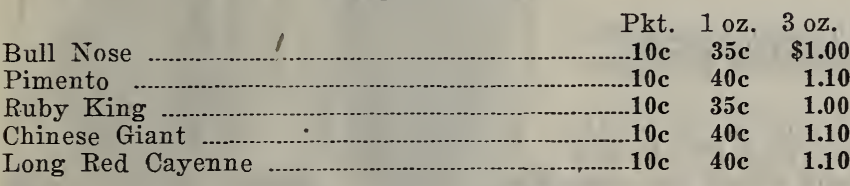

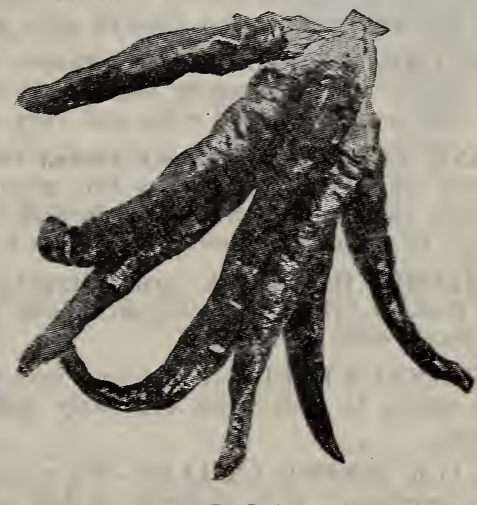

Long Red Cayenne

\section{Pumpkins}

One-half ounce will plant $100 \mathrm{ft}$. of row; three to 4 lbs. per acre.

CULTURE-Pumpkin should not be planted until danger of frost is over. They may be planted alone in hills or hills scattered through corn fields where the stand of corn is somewhat uneren. A few seeds sown in each hill will produce sufficient vines for a heavy yield. If planted alone, the hills should be spaced 4 to 6 feet each direction.

A few pumpkins grown for winter use will serve for pies and the smaller ones will make fine jack-o'lanterns for the kiddies during the fall months. Field pumpkins are ideal feed for livestock.

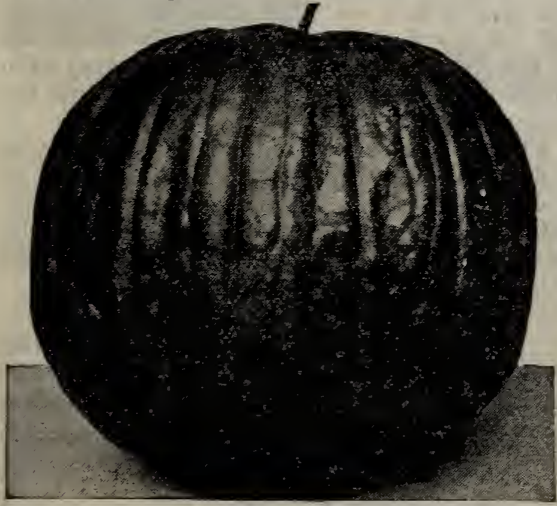

Sugar or Pie Pumpkin

SUGAR OR PIE-This pumpkin is early. in maturity and pro. duces medium sized pumpkins, slightly flattened at the ends, of golden color. The flesh is thick and of excellent quality for canning.

CONNECTICUT FIELD-One of the best varieties for stock feed because of its large size. The fruit is longer and larger around than the sugar pumpkin. The flesh is coarser in texture but desirable for stock feed.

TENNESSEE SWEET POTATO-This pumpkin is globular in shape, smaller at one end giving it a bell-like shape. The fruits are yellowish green in color and aré of excellent quality for table use. This pumpkin is nearly as early as the pie pumpkin

\section{Postpaid Prices}

Sugar Pie Connecticut Fiel Tennessee Sweet Potato
Pkt. $1 \mathrm{oz} .2 \mathrm{oz} .1 \mathrm{lb} .5 \mathrm{lbs}$. $10 \mathrm{c} \quad 15 \mathrm{c} \quad 25 \mathrm{c} \quad \$ 1.00 \quad \$ 4.50$ $\begin{array}{lllll}. .10 c & 15 c & 25 c & 1.00 & 4.50\end{array}$ $\begin{array}{lllll}10 \mathrm{c} & 20 \mathrm{c} & \mathbf{3 5 c} & \mathbf{1 . 2 5} & \mathbf{5 . 5 0}\end{array}$ 


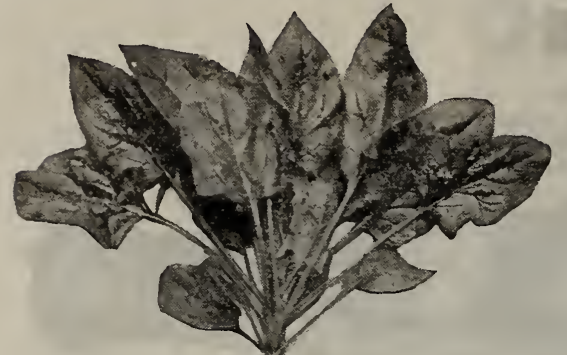

LONG STANDING-A long standing type as it does not go to seed as rapidly as other varieties. While the leaves are smaller than those of the Savoy it is suitable for late spring cropping.

IMPROVED THICK LEAVED-This variety is preferred by market gardeners for Improved Thick Leaved Spinach

fall use. The leaves are bright green in color, smooth and round and are in demand for market use.

KING OF DENMARK-A market garden variety for spring planting with deeply wrinkled dark green leaves. It is resistant to extreme weather conditions.

\section{Spinach}

One ounce will plant $50 \mathrm{ft}$. of row; ten pounds per acre. CULTURE-For spring and summer use, sow in drills one foot apart and one inch deep, as early as the ground can be worked, and every two weeks for a succession. For winter and early spring use, sow in September in well manured ground; cover with straw on the approach

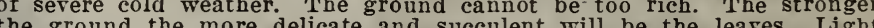
applications of nitrate of soda have often a magic effect on spinach.

BLOOMSDALE-The leaves of this variety are large, thick and deeply wrinkled and dark green in color. An excellent variety for fall and spring use.

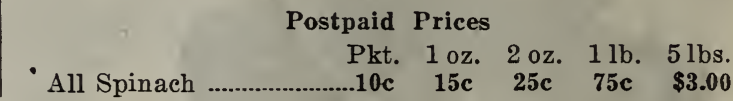

\section{Watermelons}

KLECKLEY SWEETS-One of the best known commercial melons because of its yield, quality and hardiness. It is oblong in shape with uniform dark green colored skin and dark red meat.

ICE CREAM OR PEERLESS-This is a white seeded melon simi. lar in shape to the Kleckley but the skin is light green and mottled. The flesh is a bright red color and very sweet.

KING AND QUEEN (Black seeded Ice Cream)-If you desire a variety for all summer use try this melon. It is oval in shape, producing a light yellowish green skin with brilliant red flesh and black seeds. It stands shipment well and is a good keeper.

HALBERT HONEY-A variety largely used by market gardeners. The flesh is bright red, the skin deep green in color. The seeds are black with white tips.

PHINNEY'S EARLY-An oblong variety with mottled green rind. This melon is a favorite for early home use, but is not a good keeper.

BLACK SEEDED CHILIAN-We recommend this variety for the home gardener. It is medium in size, weighing about 12 lbs., dark green in color with stripes of lighter green and bright red flesh. A very sweet, juicy melon.

COLE'S EARLY-A small round, early maturing variety with firm red flesh of delicious flavor.

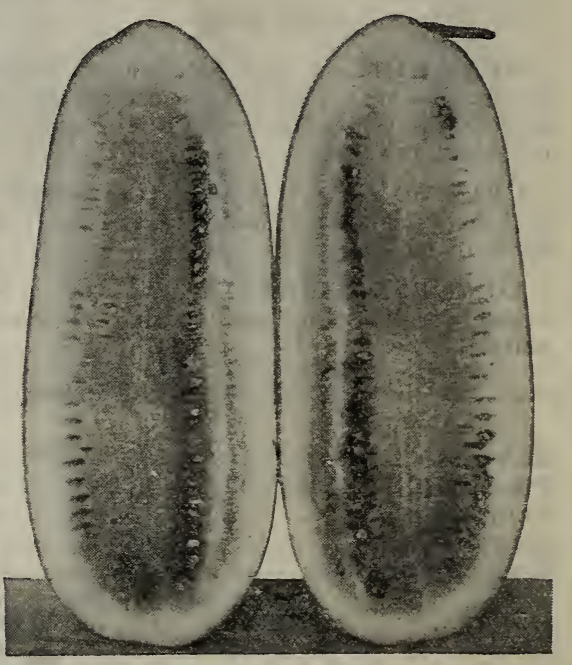

Kleckley's Sweets

GEORGIA RATTLESNAKE - A rather late variety with mottled skin and fine quality of flesh. A de-

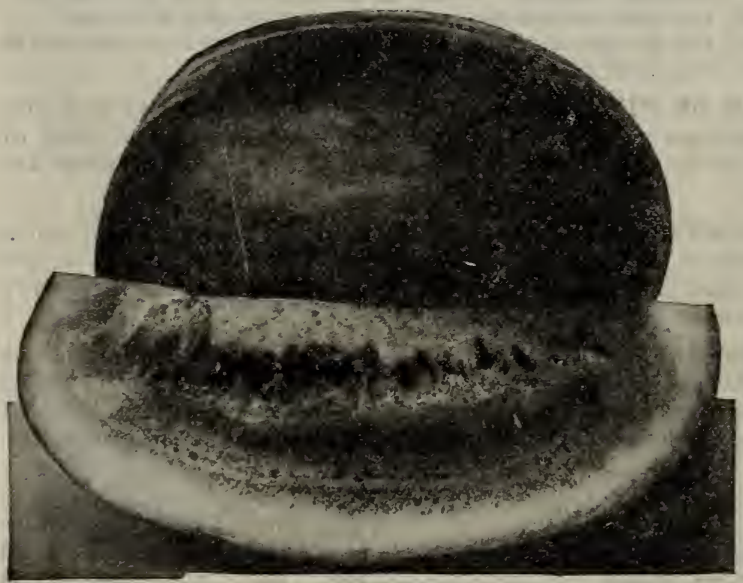

King and Queen Melon sirable melon for sections having a long growing season.

GOLDEN HONEY-Many growers prefer a yellow fleshed melon and we offer this choice variety because of its yield and flavor. The melons are about the size of Kleckley's having a mottled skin and the seeds are white with dark spots towards the tips.

TOM WATSON-A long cylindrical melon of large size and fine shipping qualities. Medium late in maturity.

KLONDIKE-A brown seeded variety used by home gardeners. It has a very firm flesh of high quality.

Postpaid Prices
Pkt. 1 oz. 20z. $1 \mathrm{lb} .5 \mathrm{lbs}$.




\section{Radishes}

One ounce will plant 100 feet of row; ten lbs. per acre.

CULTURE-Sow earl 5 and often. In good, warm loam, especially if quite saudy, summer radishes will make a crop in four to six weeks from sowing. The soll should be well prepared and fertilizers may be used freely. Have the rows a foot apart, and sow just enough so that they will not require thinning. The short turnip-rooted sorts are quickest and ensiest to grow and also good for forcing. Use fertilo Worm Repellant to control root maggots.

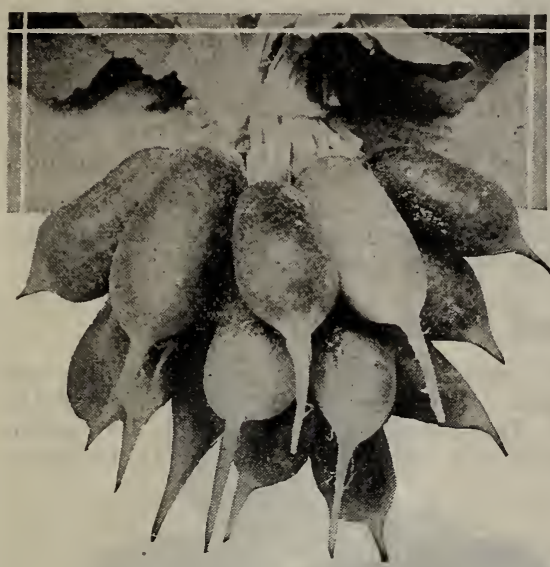

French Breakfast

CRIMSON GLANT -We consider this one of the best varieties for a commercial crop because of its size and quality. It does not be. come pithy as soon as other red varieties.

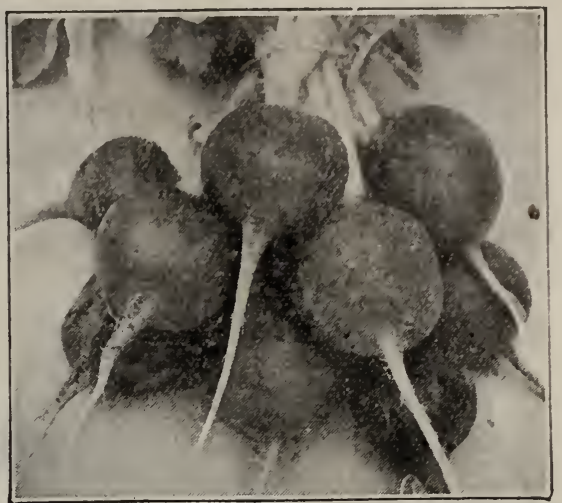

Crimson Giant It is globular in shape and has a bright red skin.

EARLY SCARLET WHITE TIP-One of the favorite varie ties for the home gardener because of its crisp quality and early maturity. A turnip shaped radish with scarlet top and white tip.

EARLY SCARLET OLIVE-This early radish has an olive shape, a bright scarlet color and white-flesh.

FRENCH BREAKFAST-One of the old standard varieties, rather oblong in shape and suitable for early use.

WHITE ICICLE-A standard variety for market and home use because of its attractive appearance and uniform shape It retains its quality if planted early in the season.

LONG SCARLET-A scarlet variety similar in shape to the Icicle but growing a more slender root.

SCARLET GLOBE-One of the earliest varieties, having a globe-shaped root, very erisp and tender.

\section{Postpaid Prices}

All Radishes

Pkt. 1 oz. 2 oz. $1 \mathrm{lb}$.

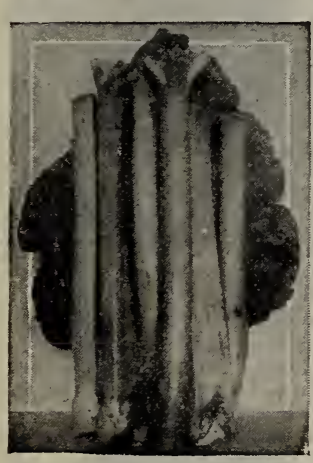

Victoria Rhubarb

\section{Rhubarb}

One ounce will produce about 700 plants

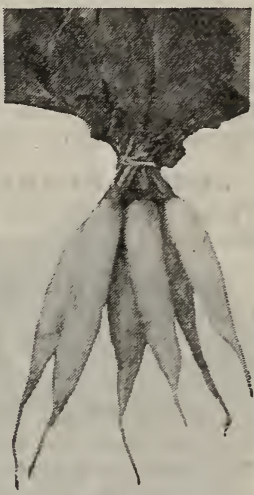

White Icicle

CULTURE-Plant the seed in rows at least one foot apart and thin the plants to about 5 inches in the row. As the stronger plants develop, thin out the weak ones and cultivate throughout the season. In the spring of the second year, transplant to a well manured plot, spacing the plants about 4 feet each way. Give plenty of cultiration, water and fertilizer for a rapidly grown crop.

VICTORIA-A large stalk variety which grows rapidly and is very succulent and free from fiber.

Postpaid Prices

Pkt. $1 \mathrm{oz} .3 \mathrm{oz} .1 \mathrm{lb}$. Rhubarb .............10c 20c 50c $\$ 2.00$

One-half ounce will plant $100 \mathrm{ft}$. of row; three lbs. per acre.

CULTURE-Rutabagas, like turnips, may be sown in ear'y spring for summer use or in late summer for fall and winter. For early crop, sow in rows and thin to 4 or 5 inches. The fall crop may be sown broadcast on clean ground, after early crops have been harvested.

AMERICAN PURPLE TOP OR YELLOW SWEDE-The most popular and generally grown varieties with yellowish skin distinctly colored with purple at the top. The flesh is very white and of mild flavor.

BANGHOLM-Preferred by many as the neck is slender and tapers toward the root making it more easily cut off at harvest.

\section{Postpaid Prices}

All Rutabagas

Pkt. $1 \mathrm{oz}, 3 \mathrm{oz} .1 \mathrm{lb} .5 \mathrm{lbs}$

$10 \mathrm{c} \quad 15 \mathrm{c} \quad 40 \mathrm{c} \quad 90 \mathrm{c} \quad \$ 3.75$

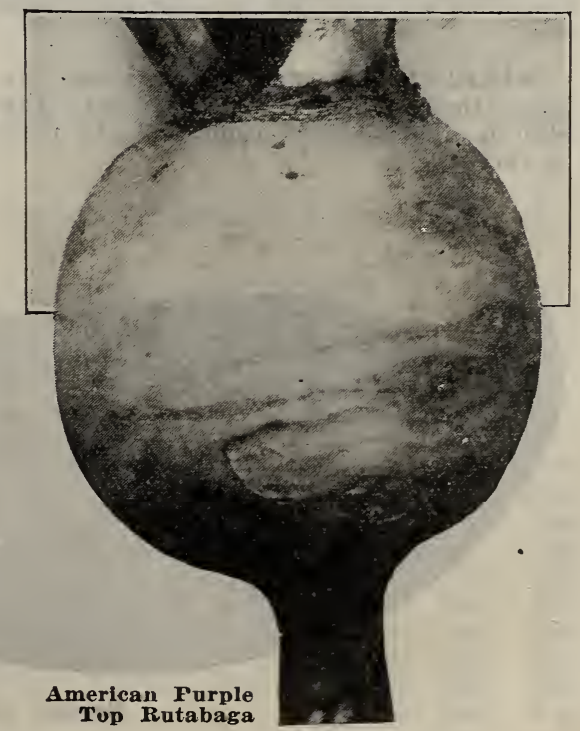




\section{Squash}

One-half ounce will plant 100 feet of row; two to three lbs. per acre.

CULTURE-Plant in well-manured hills, the bush varieties four feet apart each way, the winter sorts ten to twelve feet each way. Use seed freely, 8 to 12 seeds to the hill, to provide for losses by insects. When danger of such loss is past, thin to two or four plants to the hill. To repel the squash vine borer, throw a handful of tobacco dist close around the plants. For yellow-striped beetle and blight, spray early and repeatedly with Arsenate of Lead Mixture.

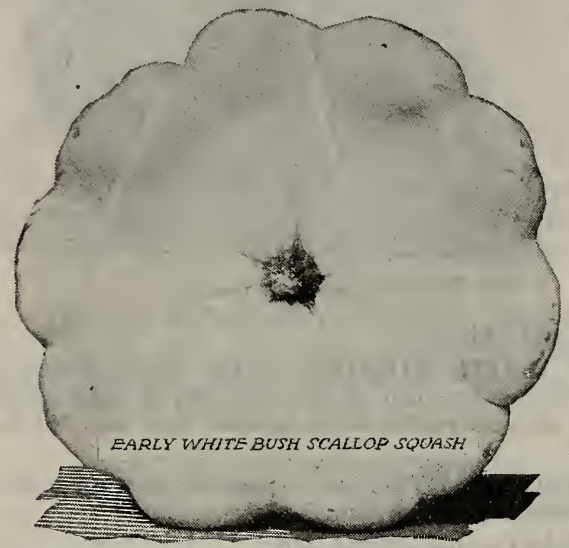

\section{Summer Varieties}

WHITE BUSH SCALLOP-A choice early summer squash for table use. The fruit is scalloped shaped, white in color and fine flavor.

YELLOW BUSH SCALLOP-These squashes are golden yellow in color and similar in shape to the White Bush. They have a very distinct flavor and are useful for eanning in late summer.

YELLOW SUMMER CROOKNECK-The fruits of this variety are elongated and somewhat warted and crooked towards the point of attachment. The flesh is solid and of good texture.

\section{Fall and Winter Varieties}

TABLE QUEEN-We recommend this variety for winter use because of its small size. It can be utilized more efficiently than the larger squash. The fruits are acorn shaped, dark green in color, distinctly ribbed with solid yellow flesh. An excellent keeper for home use.

BANANA-The skin of this squash is grayish green in color and the fruits long and tapering towards the ends. The Hesh is very firm and of a golden yellow color. A good squash for home use.

GREEN HUBBARD-An old favorite winter variety. These squashes are slightly warted, dark green in color and keep well.

GOLDEN HUBBARD-This variety is similar in shape and quality to the green Hubbard. The skin is golden yellow in color.

PIKES PEAK or SIBLEY-One of the best varieties for home use and for market. The fruit is rounded, tapering towards the ends and slightly gray green in color. It is fine squash for home use and keeps well in storage.

DELICIOUS-A top-shaped variety with dark green skin. Fruits weigh about 8 lbs. when matured and are excellent keepers.

MARBLEHEAD-Matures at about the same time as the green Hubbard. The skin is light gray in color and the flesh is very sweet.

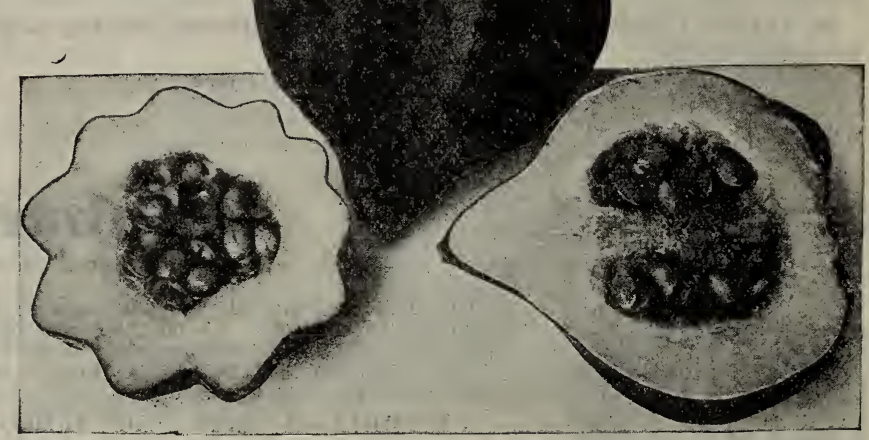

Table Queen Squash

Postpaid Prices

Pkt. $1 \mathrm{oz} .2 \mathrm{oz} .1 \mathrm{lb} .5 \mathrm{lbs}$

All Squash

$\begin{array}{lllll}10 \mathrm{c} & 15 \mathrm{c} & 25 \mathrm{c} & \$ 1.00 & \$ 4.50\end{array}$

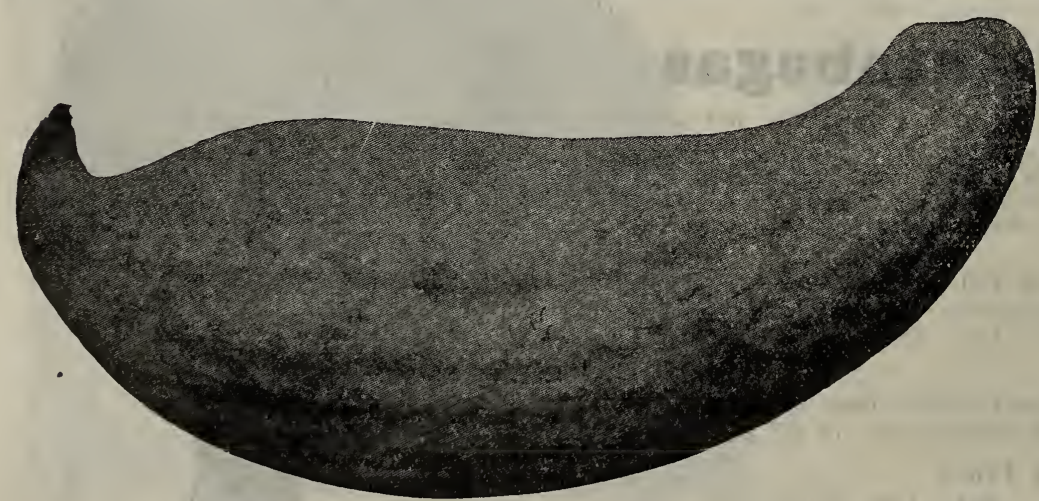

Banana Squash

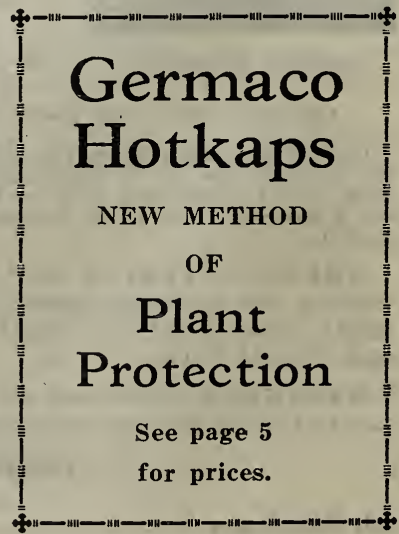




\section{Salsify, or Vegetable Oyster}

One ounce will plant $50 \mathrm{ft}$. of row; eight pounds per acre.

CULTURE-Salsify should be sown in early spring, thinning the plants to 4 or 5 inches apart in the row. If $d u g$ in the late fall, the roots are excellent for soups and boiling. They hare a distinct oyster flaror and are considered a delicacy.

MAMMOTH SANDWICH ISLAND-The best variety we hare grown because of its size and length. It is rery palatable for cooking and in crops for late fall and winter use.

Postpaid Prices

Salsify

Pkt. 1 oz. 2 oz. $1 \mathrm{lb}$. $10 \mathrm{c} \quad 25 \mathrm{c} \quad 45 \mathrm{c} \quad \$ 2.50$

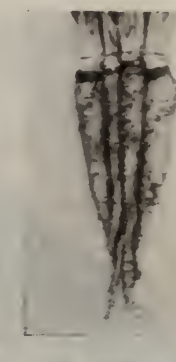

Salsify

\section{Tomatoes}

One ounce will produce 2,000 plants.

CULTURE-Tomatoes mar be started in hotbed or under glass to be readr for transplanting as soon as frost danger is over. Set out on land thoroughly prepared and free of weeds, spacing the plant 2 feet apart in the row. Often the seed may be planted in hills and a single plant allowed to grow, planting in the permanent bed where the crop is to be grown.

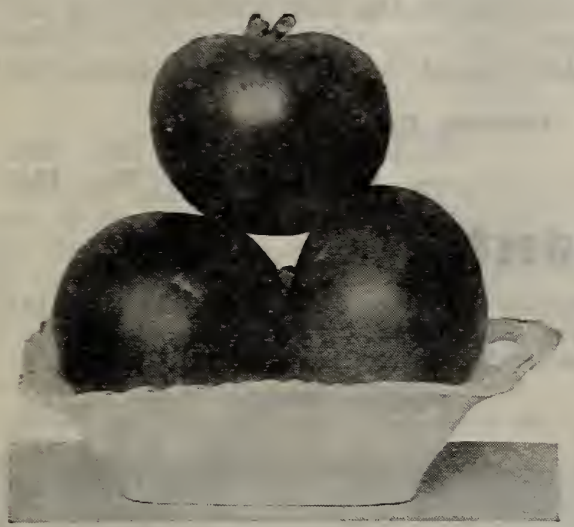

John Baer Tomatoes

JOHN BAER-Our stock of John Baer has been used by many market gardeners and has giren excellent results. It is an early rariety with rery solid flesh and a bright red color.

ACME-A well known rariety, medium early in maturity. The fruits are round, smooth, and purplish pink in color.

BONNY BEST-For the home garden tre recommend this rariety because it is early and the fruits are medium in size, rery firm, with a small seed carity.

CHALK'S EARLY JEWEL-A rariety which produces throughout the season if conditions are farorable. The fruits are large, bright scarlet in color and stand shipment well.

SPARK'S EARLIANA-We offer a special stoek of this variety which has been selected for freedom from disease, type, and shipping quality. The fruits are large, smooth, of fine texture and quality.

YELLOW PEAR-For preserving and pickling this tomato is excellent. The fruits grow in elusters and are small in size, of bright yellow in color and pear shape.

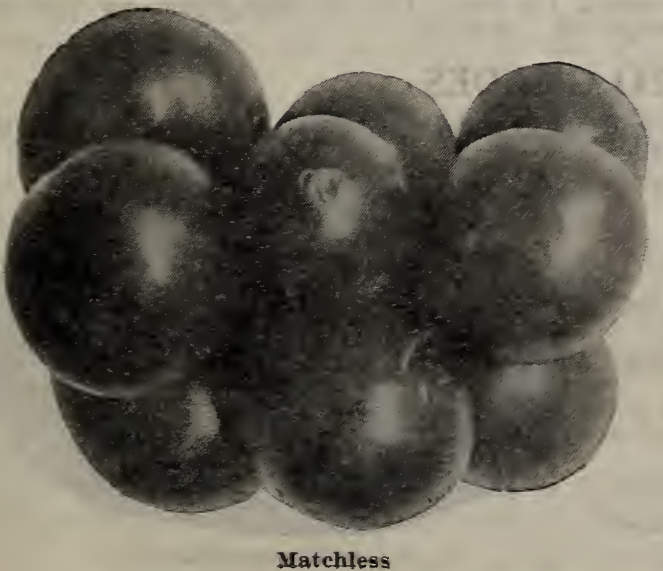

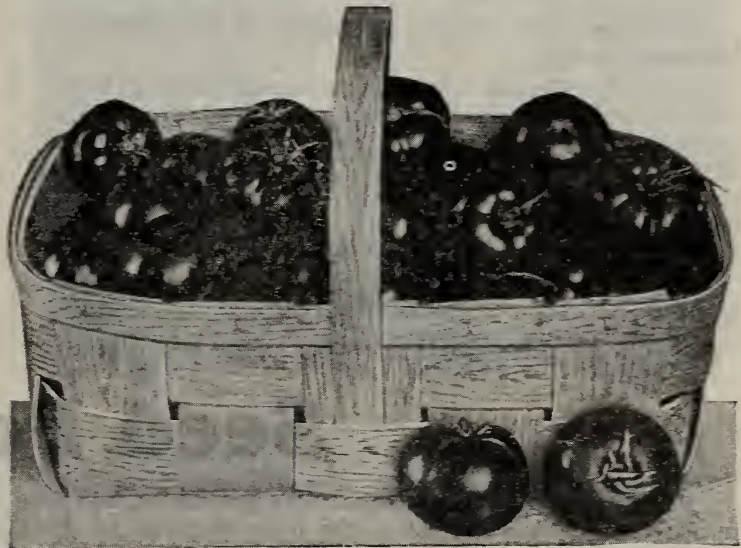

Chalk's Early Jewel

MATCHLESS-A large, smooth tomato used in many sections for canning, maturing somewhat later than Earliana.

NEW STONE-This tomato is later in maturity than Earliana. The fruits are oral, of deep scarlet color.

GROUND CHERRY-A species of tomato producing the fruit inside of a husk. The fruits are small, round and rellowish in color and are used for preserring.

\section{Postpaid Prices}

Pkt. 1 oz. 2 oz. $1 \mathrm{lb}$

John Baer 10 c 30 c 50 c $\$ 3.50$

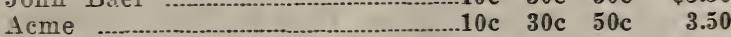

Bonne Best $\quad 10 \mathrm{c} 30 \mathrm{c}$ 50c $\quad 3.50$

Chalk's Earlז Jerrel ……........................ $30 \mathrm{c}$ 50c

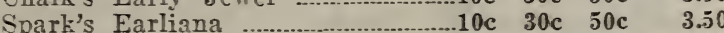

IIatchless ……...................................... 25 c 40

Vew Stone

Ground Cherry $\quad-10 \mathrm{c} \quad 40 \mathrm{c} \quad 75 \mathrm{c} \quad \mathbf{5 . 5 0}$

Fellow Pear 


\section{Turnips}

One-half ounce will plant $100 \mathrm{ft}$. of row; three lbs. per acre.

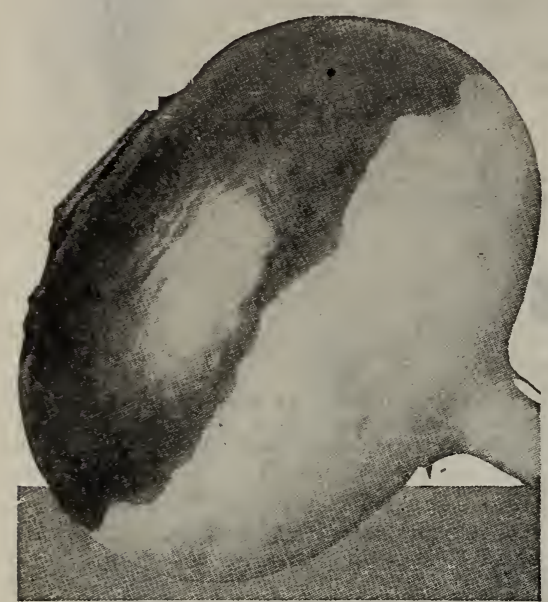

Purple Top Strap Leaf

CULTURE-For an early crop, turnips may be sown in rows in early spring, thinning to several inches apart in the row as they develop. The main crop is sown under irrigation as soon as a grain crop is harrested, sowing the seed with a drill or broadcast, following with a harrow. If the grain stubble has been irrigated thoroughly before discing, the crop will generally grow rapidly.

PURPLE TOP STRAP LEAF-One of the most popular varieties, producing a flat root, white with purple top, and a fine mild flavor. An excellent variety for commercial planting.

PURPLE TOP WHITE GLOBE-Similar in quality to the Strap Leaf, but of globe shape.

GOLDEN BALL OR ORANGE JELLY-One of the best yellow varieties for the home garden and of fine appearance for market use. A choice variety for early spring planting.

AMBER GLOBE-Medium in size, with a small top. An early variety with tender flesh of mild flavor. The root is globe shaped, and keeps well.

SNOWBALL or WHITE EGG-We suggest this turnip for the early spring garden. It is of small size, with pure white flesh, and mild flavor.

EARLY WHITE MILAN-One of the earliest flat varieties, with white skin.

All Turnips

Postpaid Prices

Pkt. $1 \mathrm{oz}, 2 \mathrm{oz} .1 \mathrm{lb} .5 \mathrm{lbs}$. $10 \mathrm{c} \quad 15 \mathrm{c} \quad 25 \mathrm{c} \quad 75 \mathrm{c} \quad \$ 3.50$

\section{Vegetable Plants}

Our Plants Are Grown by Roselawn Greenhouses, Moscow, Idaho.

All of the plants offered, are hardy, having been transplanted and hardened out of doors before ship. ment. Plants are carefully packed to reach you in the best possible condition. Place your order early. specifying date for delivery. Cabbage plants and Cauliflower ready April 1st; Celery, Tomato and Pepper plants ready May 1st.

Cabbage Varieties: Early Jersey Wakefield, Copenhagen Market and.Danish Ballhead.

Celery: Golden Self Blanching and White Plume.
Cauliflower: Early Snowball and Danish Giant. Peppers: Ruby King.

Tomatoes: Spark's Earliana.

\section{Postpaid Prices}

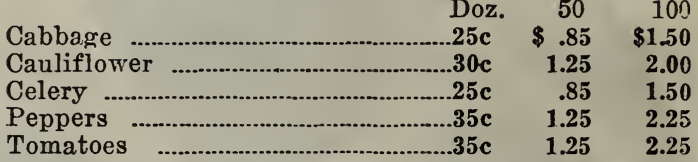

WRITE FOR SPECIAL PRICE LIST ON BEDDING PLANTS.

\section{Seed Potatoes}

Our seed stock of potatoes was grown on our own seed farm the past season and we are endeavoring to improve all of our stocks to the highest point of freedom from disease and yield. Such work requires constant observation and study and a thorough knowledge of potato types and diseases.

We not only handle seed grown on our own farm, but seed grown by other growers under the supervision of State Authorities. These stocks are inspected during the growing season and rogued many times to eliminate weak and diseased plants, so that they will not infect the healthy plants. After passing the field inspections, they are then sorted to the State Grade and are ready for shipment.

It is imperative for you to secure seed which either carried the State Tag, or seed which we have approved as it may mean the difference between a good crop and a failure.

\section{OUR SEED POTATO GRADES}

State Certified Stock which has been grown, rogued, and inspected under the rules established in the various states for the certification of seed potatoes. The potatoes are packed in new bags of $100 \mathrm{lbs}$. net weight and State Certification Tags Accompany Shipment.

Approved--Seed potatoes which have passed two field inspections and have been sorted to a good commercial sort to meet the requirements for this grade, put up in bags $100 \mathrm{lbs}$. net weight.

Varieties Offered: Bliss Triumph, Irish Cobbler, Early Red Ohio, Idaho Rural, Netted Gem.

See Insert Sheet for Prices.

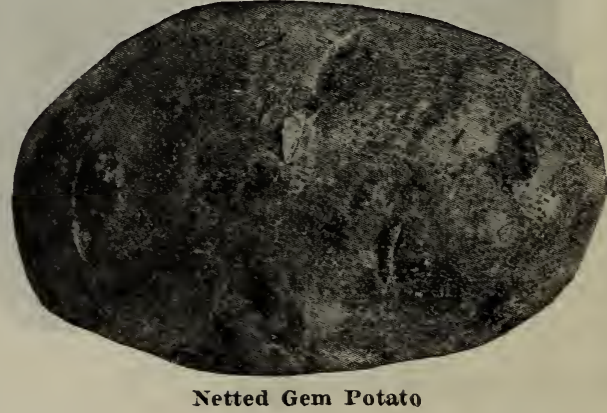




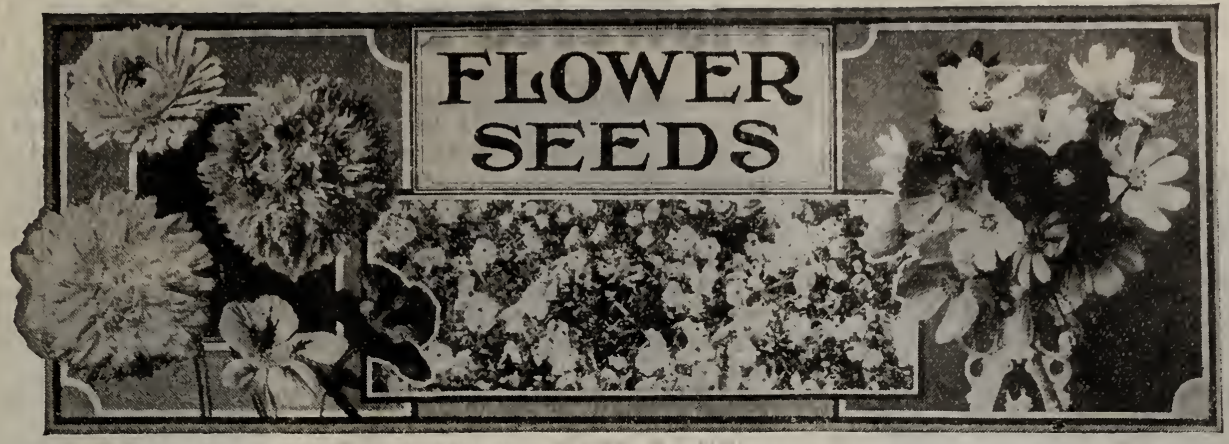

\section{Our Specials for 1928}

You may purchase our flower packets from our seed cabinets in your local store or direct. All packets are packed by us from the very best stocks obtainable. We have inspected the fields from which many of these stocks were grown and use only the highest grades of flower seed in our packets.

\section{Asters}

CREGO GIANTS-The Crego Giant Asters are early enough for the higher elevations if the plants are started indoors, transplanting as soon as weather conditions permit. These asters are free blooming with flowers of large size. The petals are wavy and curled and the center indistinct. We offer the following colors: Crimson, pink, lavender, purple, white, and assorted mixed colors.

Single packet $10 \mathrm{c}$; 5 separate colors $45 \mathrm{c}$, postpaid.

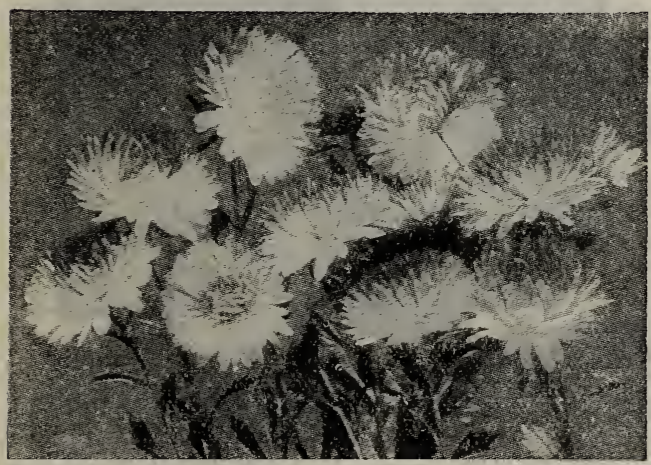

Early American Beauty

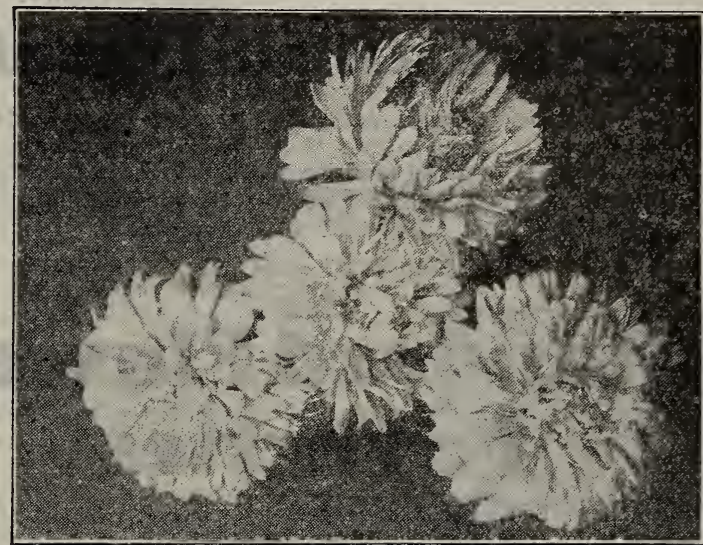

Crego Asters

EARLY AMERICAN BEAUTY-While a new type of aster, they are very popular. The plants are branching with long stems, the flowers more compact with in-curled petals forming a solid uniform flower. We can supply you with the following colors: Crimsqn, purple, lave der. peach blossom, September Beauty (flesh pink), and assorted mixed colors. (See inside back cover.)

Single packet $10 \mathrm{c} ; 5$ separate colors $45 \mathrm{c}$, postpaid.

HEART OF FRANCE-If you desire a rich dark red variety for real beauty, this aster is outstanding in quality. It is medium early in bloom and one of our favorites. Packet 10c, postpaid.

\section{Sweet Peas}

Special Late Flowering Spencers

MARY PICKFORD-If you desire a beautiful light pink with large wavy petals, you will find this the best of our offering. The plants are vigorous, producing from three to four large flowers per flower stalk.

DEFIANCE-This large orange scarlet is one which holds its color in extreme sunlight and one which you should include, as it fits into your flower schemes where strong color is desired.

HEAVENLY BLUE-It is true to its name, just the kind of blue that is of purest color, free of all trace of violet. The flowers are large and wavy petaled and a very profuse bloomer.

SNOWBALL-A very recent introduction of purest white and large bloom. The flowers are hardy and keep well when used for home decorations.

Special Sweet Peas: Single packet 15c; Oz. 50c, Postpaid.

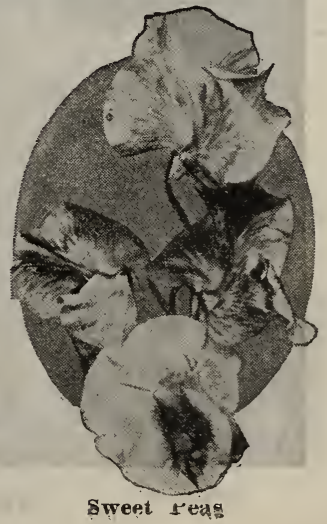




\section{Dahlia Flowered Zinnias}

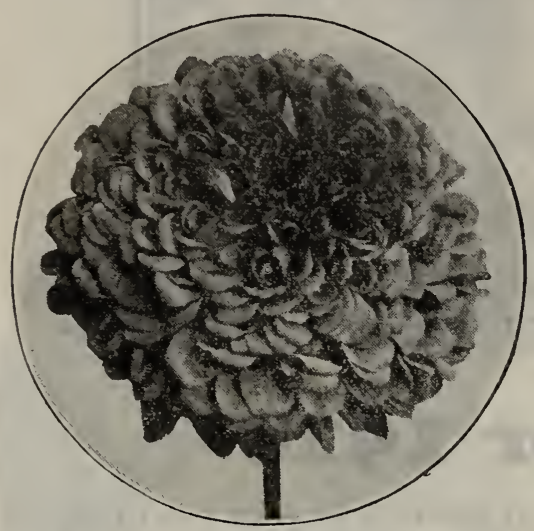

Dahlia Flowered Zinnia

The old fashioned plain Zinnia is gone and the large Dahliaflowered varieties are in their prime. The flowers of this type are as large as the Mammoths and the petals are somewhat cup shaped, giving them the appearance of a Dahlia. Zinnias are easily grown in the home garden and will bloom profusely the entire summer season. They make excellent bouquets and are fine for home decorations.

CRIMSON MONARCH-A brilliant deep red.

DREAM-A beautiful lavender of intense color.

EXQUISITE-The petals are of light rose with a center of deeper rose.

GOLDEN STATE-This orange yellow is outstanding for its depth of color and beauty.

POLAR BEAR-An immense flower of pure white.

Mixed Colors $\rightarrow$ Special mixture with great variety of colors. Single packet $15 \mathrm{c} ; 5$ packets $60 \mathrm{c}$, Postpaid.

\section{Lilliput Zinnias}

We ask you to try this novelty because it is different from any Zinnia you have grown. The plants are similar to the large Zinnia, but the flowers are small. The flowers are just as perfect as the Dahlia flowered and Giants, but do not grow larger than $11 / 2$ to 2 inches in diameter. They make an excellent flower for bouquets and table decorations.

Assorted Colors: Packet, 15c, postpaid.

\section{California Giant Petunias}

The California Giant petunias are very large, distinctly ruffled, and fringed along the edge of the petals. The seed should be started under a cold frame and the plants transplanted after frost is passed. Grow your plants from our seed and you will be more than pleased.

Assorted Colors: Packet, 25c, Postpaid.

\section{Standard Flower Favorites}

AgERATUM (Blue Perfection)-This is a wonderful plant for borders. The plants are very dwarf with masses of feathery blue flowers. They add a real touch to your ornamental garden. Packet 10c, Postpaid.

ILYSSUM-If you desire a white border, this plant will serve you well as it blooms profusely, with masses of small white sweet-scented flowers. Packet 10c, Postpaid.

IIARANTHUS TRICOLOR (Joseph's Coat)-This plant is cesirable in the flower garden because of its variegated leaves. It is used in mass plantings on poor soils. The leaves have varying shades of red, green, and yellow. Packet 10c, Postpaid.

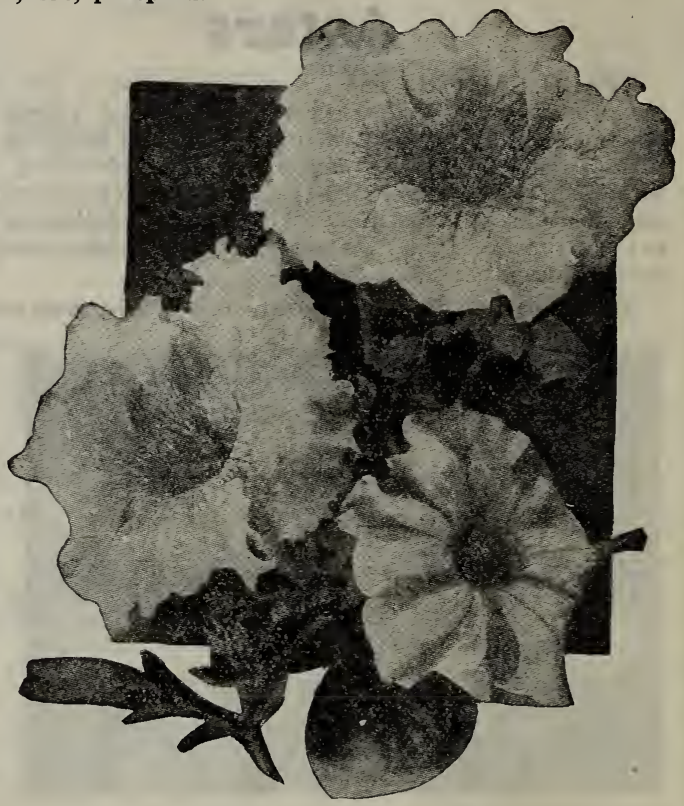

California Giant Petunias

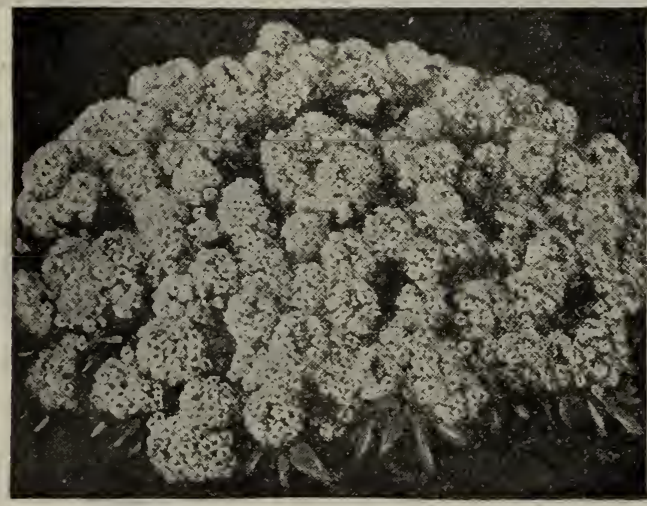

Alyssum
ARCTOTIS GRANDIS (African Daisy)-A fine annual daisy to produce a variety of color in your flower bed. The petals are white to silvery blue with a darker blue center. Packet 10c, Postpaid.

ASTER, Needle Mixed-As a novelty, this type of aster is worthy of a trial. The petals are long, slender and sharp pointed. The plants are vigorous and profuse bloomers.

\section{See Special Flower List for Other Asters}

BACHELOR'S BUTTON-An old fashioned favorite for mass planting and waste spaces around the garden as it does well on poor soil with little care. Height $2 \frac{1}{2}$ feet, shades from blue to white and rose in flower color. Packet 10c, Postpaid.

BALSAM-An ideal plant for massing and tall borders. The rose-like flowers are borne in the axil of the lesves and come in a great variety of colors, Packet $10 c_{2}$ Postpaid. 


\section{Standard Favorite Flowers-continued}

CAleNdula (Pot Marigold)-One of the hardiest annuals for mass planting an? borders. It grows to a height of 15 to 20 inches and produces an abundance of orange and rellow flowers. Pkt. 10c, Post. paid.

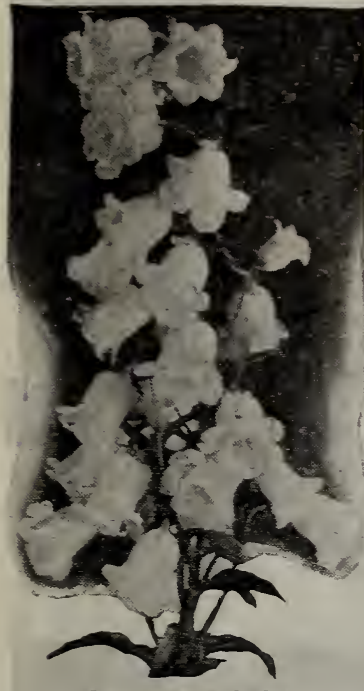

Canterbury Bells

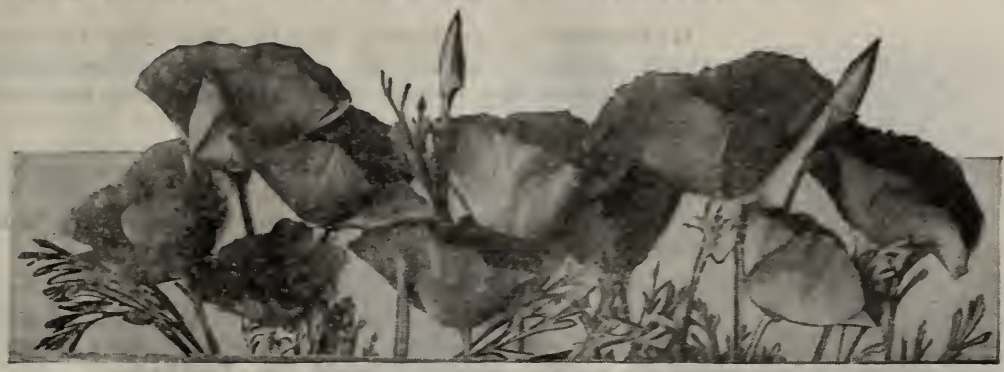

California Poppies

CALIFORNIA POPPY (Eschscholtzia) - A low growing annual reproducing from seed in favorable locations. The flowers vart in color from sellows, to brown, red, and white and are excellent for mass plantings on banks and exposed locations. Packet 10c, Postpaid.

CALLIOPSIS (Coreopsis)-Hards annuals with long graceful flower stalks. $\pi$ ell adapted to bouquets and group planting. The flowers vary in color from rich maroon, brown to yellow. Packet 10c, Postpaid.

CANDYTUFT-One of the low growing annuals for borders. The plants produce compact tufts of various-colors and blend $\pi$ ell with rarious color schemes in the flower garden. Packet $10 \mathrm{c}$, postpaid.

CLARKIA-Very hardy annuals producing clusters of flowers somewhat sepa. rated along the stem. A very effective plant when scattered among hardy shrubs to add color to the planting. Packet 10c, Postpaid.

CHINESE WOOLFLOWER-The branches of this hardy annual, which grows to a height of 2 to 3 feet, terminate in a large ball of rich relretr dark red color. The flowers are effective for table decorations. Packet 10c, Postpaid.

CANTERBURY BELLS-A biennial, which if sown very early in the spring will generally flower during the first season. The plants grow from 3 to $t$ feet in height and are desirable in the rock garden. Pkt. 10c, Postpaid.

COCKSCOMB-A moderately low growing annual with large dark red comb-like flowers. Try these in your garden to appreciate their value. Packet 10c, Postpaid.

COLUMBINE - A farorite perennial for the rock garden and for individual planting among perennial shrubs. After the roung plants are started in the cold frame, transplant to the permanent location and they will bloom from vear to sear. The flowers are large, often double, and rary in shade from white to purple. Packet 10c, Postpaid.

DELPHINIUM-Another desirable perennial for the rock

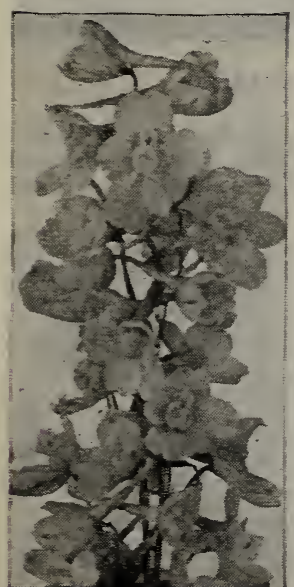

Deiphinium garden and for mass planting in the corners and background. These plants are grown in a variety of shades of blue and purple. Packet 10c, Postpaid.

ENGLISH DAISY - A beautiful low growing perennial for permanent borders for malks, rock gardens and for use in lawns. The plants are hardy and will bloom from sear to year with little care. The flowers are found in white, pinks, and red color. Packet $10 \mathrm{c}$, Postpaid.

Cosyos-In attractive annual for bouquets and home decoration. The flowers are borne on long slender stems, rart ing in shade from white to red. The plants grow to a height of \pm or 5 feet. Packet 10c, Postpaid.

$\$ 1.00$ Postpaid.
\$1 Packets of Flowers Listed at 10

FORGET-ME-NOT-Well suited to moist cool locations. It is a hardy perennial, which blooms in early spring and fall. The flowers are of a delicate blue color. Packet 10c, Postpaid.

FOXGLOVE (Digitalis)-A perennial which seldom blooms until the second season from seed. The flowers are borne on long dense spikes and are rery shorry. These plants should be used in the back ground or borders of the garden. Packet 10c, Postpaid.

Write us for special price list of Gladioli Bulbs, Roses,
Peonies, and Fruit Trees. All stocks are local grown and very
hardy.

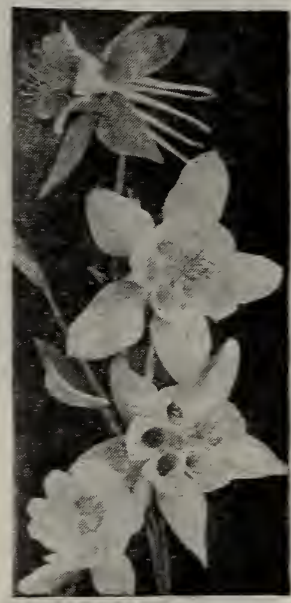

Columbine

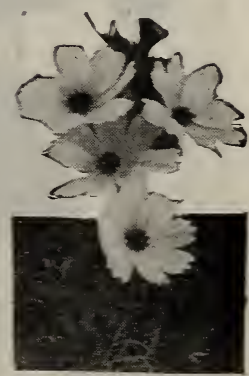

Cosmos 


\section{Standard Favorite Flowers-continued}

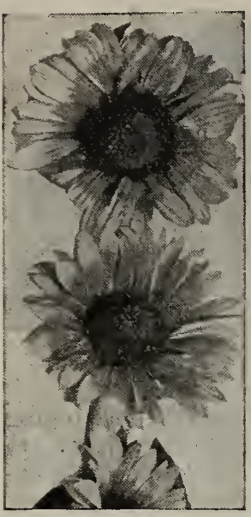

Gaillardia

GYPSOPHILA or Baby's Breath-We offer the annual variety which is used extensively in bouquets. The stems are finely branched and the flowers are small, delicate, and white in color.

Packet 10c, Postpaid.

GAILLARDIA-Hardy annuals growing to a height of $11 / 2$ feet, producing a profusion of showy orange and yellow flowers. They are suited to mass planting and for cut flowers. Packet 10c, Postpaid.

HOLLYHOCK-These hardy perennials should be included in every flower garden. They will aid in covering an unsightly fence or the side of a building. Seed should be sown in spring for flowers the second season. Packet 10c, Postpaid.

KOCHIA (Firebush)-A distinct bush-like annual easily grown for its foliage. It makes a very effective hedge or border for walks and drives by spacing the plants about 2 feet apart. The plants turn to reddish brown color in late fall. Packet 10c, Postpaid.

LARKSPUR-The Annual Larkspur should be sown in the hot bed and the plants transplanted to the garden as early as the season permits. They bloom throughout the season and are fine as cut flowers. They are found in a wide range of colors. Height 3 to 4 feet. Packet 10c, Postpaid.

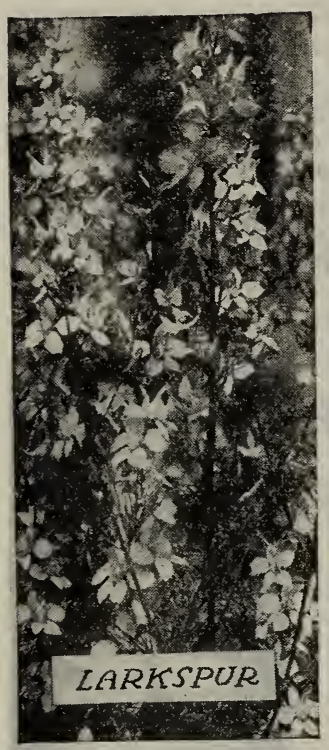

LINUM (Red Flax)-A novelty for use in borders. The plants are similar in height to the cultivated flax, but the flowers are a bright red. Packet 10c, Postpaid. Also used in window boxes and for pot culture. Packet 10c, Postpaid.

MARIGOLD (Tall Double African) - These annuals grow to a height of 3 to 4 feet and are adapted to strong sunlight exposure. They develop a large ball-like flower with brilliant orange and yellow color. Packet 10c, Postpaid.

MIGNONETTE (Sweet Scented)One of the choice bedding plants used for cutting. Should be sown in hot bed and plants set out in succession for summer bloom. Height 12 to 18 inches. Packet 10c, Postpaid.

MORNING GLORY-A favorite annual for use on trellis or porch. The plants grow rapidly during the hot season and have large flowers of various colors. Packet 10c, Postpaid.

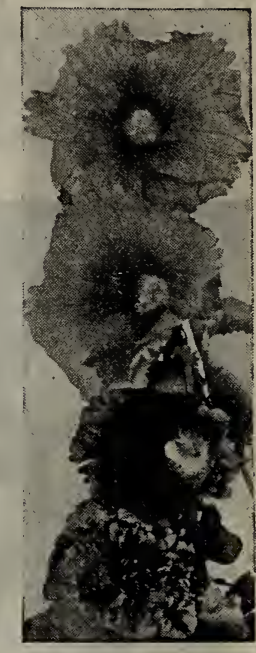

Hollyhocks

LOBELIA-A low growing plant used for borders, producing small blue flowers.

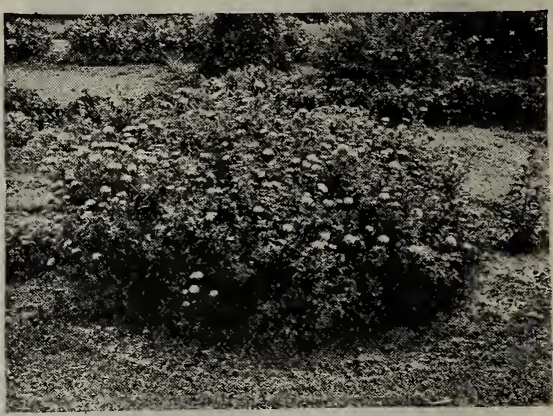

Marigold

NASTURTIUMS--These hot season annuals are included in most flower gardens as they grow well on poor soil and in extreme sunlight. The tall growing varieties are used for window boxes and

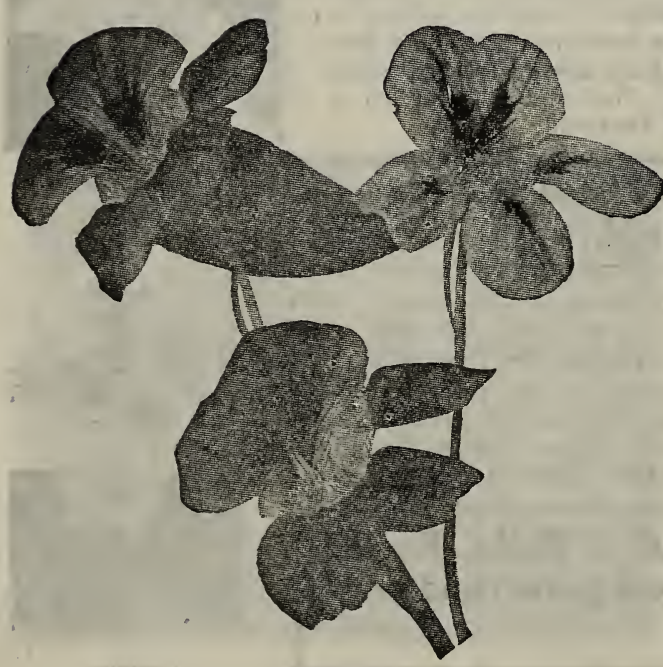

Nasturtiums low trellis while the dwarf are suited to border use. Sow after danger of frost is passed.

Tall Assorted Colors: Packet 10c; 1 oz. 25c, Postpaid.

Dwarf Assorted Colors: Packet 10c; 1 oz. 25c, Postpaid.

ORIENTAL POPPYOne of the most attractive perennials as the large single flowers are a rich dark red color. Plants are easily grown from seed and will bloom each season with little care. Packet 10c, Postpaid.

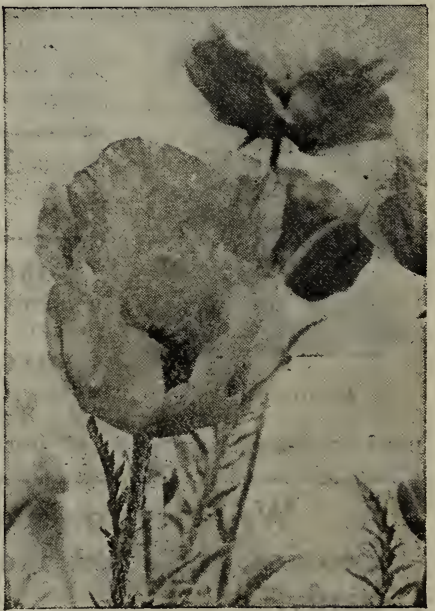

Oriental Poppies 


\section{Standard Favorite Flowers-continued}

PANSY-Our strain of pansy is the Oregon Giant and has been selected for size of flowers and beautiful colors. Pansies should be started in the cold frame and transplanted to the permanent bed during the early spring. With some protection, they will live over winter. Packet 10c, Postpaid.

PETUNIA-The common Petunia is adapted to exposed locations and will do well on poor soil. They bloom early and until frost, and should be started indoors, transplanting as soon as the season permits. Assorted Colors:....Packet 10c, Postpaid.

See Special Flower List for California Giant Petunias.

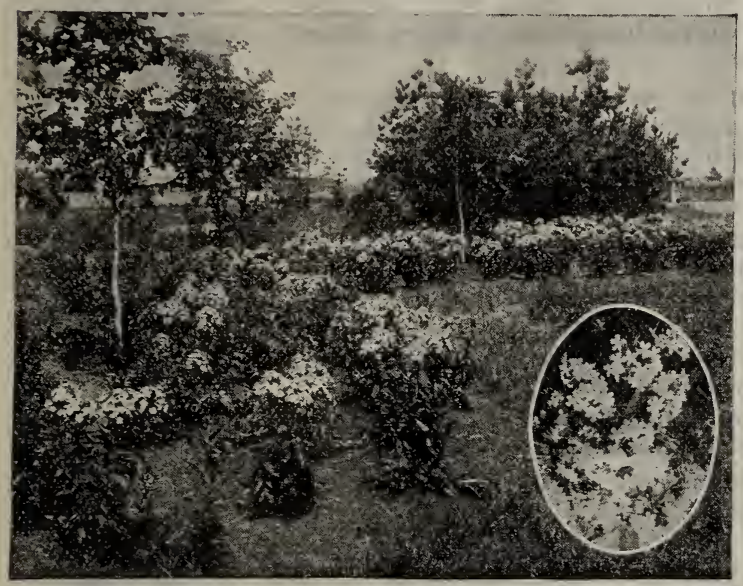

Phlox

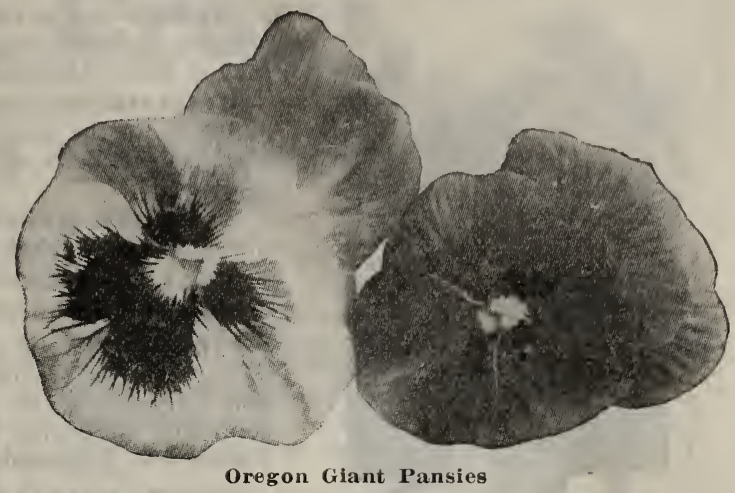

PHLOX (Drummondi)-One of the finest bedding plants grown, as the flowers are produced in a wide variety of colors and give a fine eolor effect from mass planting. Height 12 to 16 incheș. Packet 10c, Postpaid.

POPPY (Double)-Double Poppies make a desirable annual flower to add to the variety in the flower garden. They are easily grown from seed and when planted in succession, will furnish flowers throughout the season. Assorted colors: Packet 10c, Postpaid.

PORTUlaCA (Moss Rose)-These low-growing annuals are fine for rock gardens and borders. They produce an abundance of rich glossy cupshaped flowers. Assorted colors: Packet 10c, Postpaid.

PINKS (Dianthus)-A hardy well known flower found in most home gardens. The double types are suitable for

cut flowers and are profuse bloomers. Assorted colors: Packet 10c, Postpaid.
SALVIA (Scarlet Sage)-It is necessary to start these plants indoors, transplanting to the permanent bed after frost. Salvia grows to a height of 2 to 3 feet, producing dark green foliage and brilliant scarlet flowers, excellent for massing. Packet 10c, Postpaid.

SALPIGLOSSIS-You should grow this beautiful flower for its large glossy velvet-like flowers. The flowers are found in a wide range of colors and are fine for interior decorations as well as adding variety to the flower garden. Height 3 to 4 feet. Packet 10c, Postpaid.

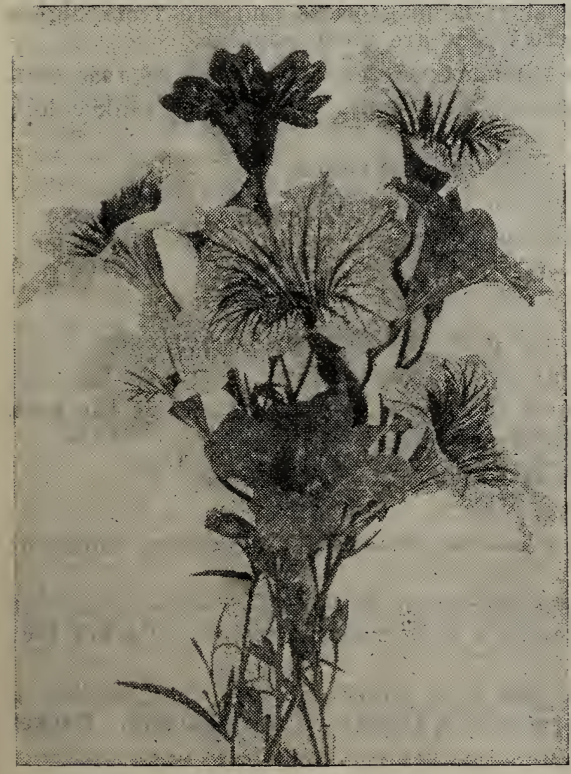

SCABIOSA (Mourning Bride)-A flower which has become a favorite in every home garden. Useful for cutting, as they keep well and make a beautiful bouquet. An annual growing to a height of 2 feet. Pkt. 10c, Postpaid.

SCARLET RUNNER BEAN - A bean often grown for table use, but generally used to cover a trellis or shade for porches. The flowers are a brilliant red in color, the seeds very large, reddish brown, and mottled. Packet 10c, Postpaid.

SHASTA DAISY-A very attractive perennial with large white flowers, Pkt. 10c, Postpaid.

SNAPDRAGON (Antirrhinum) - While considered as an annual, these flowers will often live over winter if given some protection. They are excellent for beds, pot culture, and cut flowers. Assorted colors: Pkt. 10c, Postpaid.
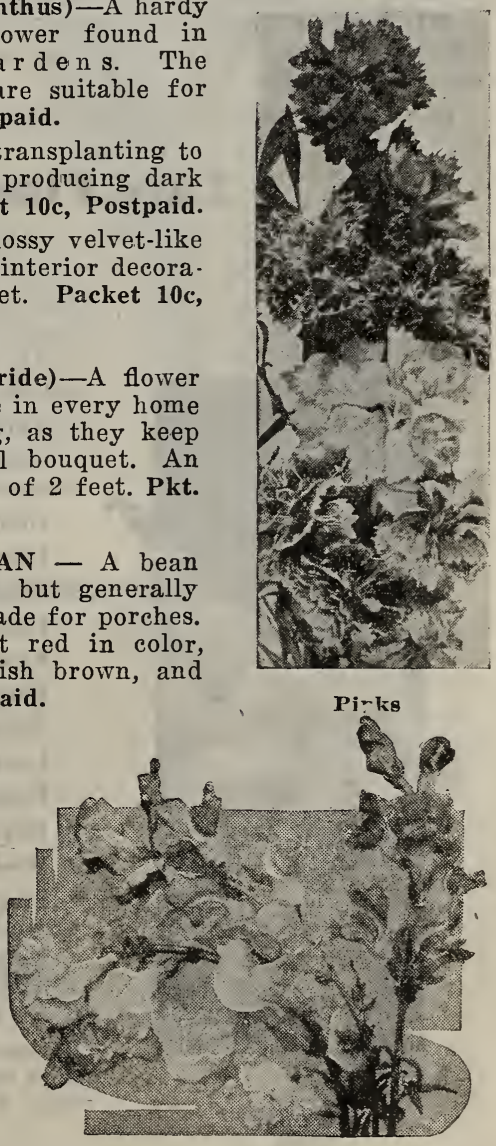

Snapdragon 


\section{Standard Favorite Flowers-continued}

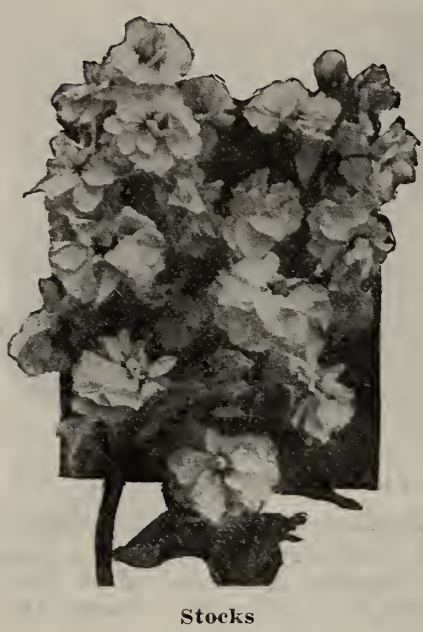

STOCKS-An early blooming plant with large clusters of showy flowers, suitable for bedding and border planting. Plants are annuals 12 to 18 inches tall. Assorted colors: Packet 10c, Postpaid.

SUNFLOWER-The old-fashioned sunflower has been improved with the addition of the dwarf double variety. The annual plants are fine for use along fence rows or buildings. They add color to the garden during the early fall.

MAMMOTH RUSSIAN-A tall growing rariety with mammoth large yellow flowers. Packet 10c; 1 oz. 15c, Postpaid.

DWARF DOUBLE--A distinct novelty because of their. dwarf growth and double yellow flowers. Packet 10c, Postpaid.

STRAWFLOWER (Helichrysum)-These hardy annuals are effective for massing in the garden and after full bloom may be picked and dried, retaining their color and shape for winter bouquets. Assorted colors: Packet 10c, Postpaid.

SWEET WILLIAM-A perennial, which blooms ir early spring and later in the season. The flowers are borne on tall stems 2 to 3 feet in height and are found in a variety of colors and patterns. Packet 10c, Postpaid.

TRITOMA (Red Hot Poker) - This perennial requires a season or two to attain its perfection. The plants are medium short, producing a tall flower spike with brilliant scarlet flowers, thus giving it the name Red Hot Poker. A valuable plant for the permanent garden for early bloom. Packet 10c, postpaid.

VERBENA-One of the favorite annuals found in older gardens. It is often used in window boxes and for mass planting. Assorted colors: Packet 10c, postpaid.

WALL FLOWER-Height 1 to 2 feet, with flowers of rich reds and yellows. A halfhardy perennial generally blooming first year from seed. Packet 10c, postpaid.

WILD FLOWER GARDEN-A mixture of the farorite annuals for use in covering bare areas in the garden which might be covered with weeds. Plant it and see if you can identify the varieties grown. Packet 10c, postpaid.

WILD CUCUMBER-A rapid growing annual for use on porch or trellis, making a quick effective shade. It will generally re-seed itself for the following season. Packet 10c; oz. 20c, postpaid.

ZINNIAS—See Special Flower List for Dahlia Flowered and Lilliput Zinnias.

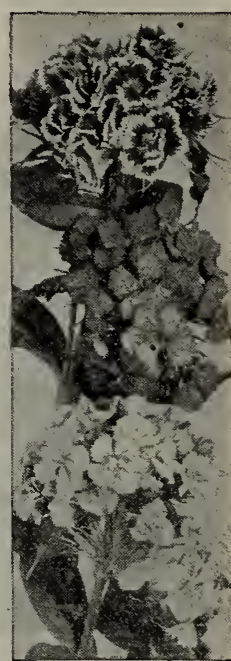

Sweet Williams

\section{Late Flowering Spencer Sweet Peas}

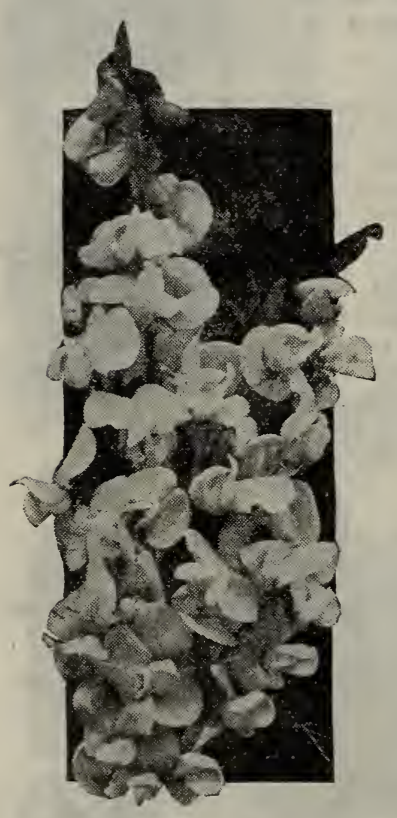

Sweet Peas

CULTURE-Sweet peas do best if seeded in the late fall or very early spring. The soil should be spaded quite deep and should be well fertilized with well rotted manure. The seed should be sown at a depth of two and a half to three inches, spacing the seeds about one to two inches apart in the row, later thinning to the desired stand. Sweet peas should be sown where they will secure the best sunlight.

All of our Sweet Peas are from most reliable growers and are from highly selected stocks. We offer those varieties that are most popular.

Apple Blossom-Large flowers with wings primrose with a flush of rose tint.

Countess Spencer-One of the old standard Spencers with a clear pink color; flowers large and wavy petaled.

Dobbie's Cream-A favorite with creamy colored petals.

Fiery Cross-A brilliant cerise orange of strong color.

Hercules-A giant clear pink of uniform color.

Illuminator-An orange salmon of striking color.

King White-A fine clear white.

King Edward-One of the old standard pure red Spencers of large size.

Margaret Atlee-This deep clear pink is an old standard.

Lavender George Herbert-We suggest this pure lavender as one of the best.

Primrose-Large flower of purest primrose color.

Royal Purple-Rich purple in color with flowers of large size.

Wedgewood-Of a bright blue color.

Single packet Named Variety 10c; 1 oz. 25c, Postpaid. 5 packets, choice of varieties, 45c, Postpaid.

Sweet Pea Mixture-We offer our special strain of mixed sweet peas for the critical trade. All choice late varieties in a wide range of colors. Packet 10c; $1 \mathrm{oz}$. 20c, postpaid.

Grandiflora-A mixture of colors in this type, which are somewhat smaller in size than the Spencers, but often grown to add variety to the planting. Packet $10 \mathrm{c} ; 1$ oz. 15c, postpaid. 


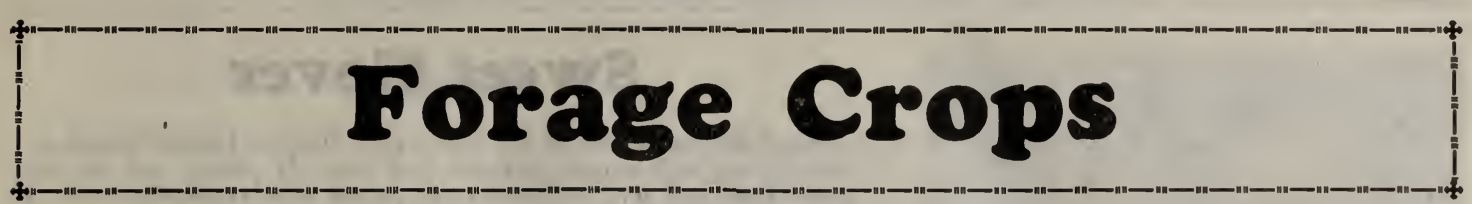

\section{Our Seed Grades}

Our seed grades are established with our regular customers but for the benefit of our new customers, let us describe them again.

Our "SUPREME" brand is the nearest perfect that can be offered. This seed contains very few, if any weeds, and then only those considered as harmless. It has an excellent color, is free of inert matter, and has a high vitality.
Our "IDEAL" brand is just as free of noxious weeds, but may contain a few harmless weeds, or a slight mixture of other crop seeds that are valuable in a hay crop. A saving in the cost of seed can be had if your crop is to be used for hay or pasture by purchasing this brand.

We could offer you cheap seed at lower prices, seed that contained noxious weeds, weather damaged seed, mixtures and the like, but we want you to feel free to order from us each season. We will endeavor to give you the best values for your money that can be offered. Remember that a COPY OF STATE TEST OF SEED WILL BE SENT (ON REQUEST.

\section{Alfalfa}

Alfalfa is the most widely used of the hay crops, because it is adapted to a wide range of climatic conditions as well as soils. More alfalfa should be sown in non-irrigated sections for hay and late fall pasture. Old fields should be plowed up and sown to other erops, seeding down new areas for the improvement of the soil.

It is profitable to apply about $200 \mathrm{lbs}$. of gypsum or landplaster to the soil in the late fall or early spring. This should be added to land which is to be sown to alfalfa in the spring, as well as to older established fields.

\section{Grimm Alfalfa}

This is a distinct variety of alfalfa developed in Minnesota. It produces a heavier, more branching root system than the common alfalfa and the flowers are variegated in color. We recommend this variety where winter-killing is a problem, but elsewhere the common alfalfa is as satisfactory.

State Certified. This is our best grade of Grimm offered. It carried a blue tag which is sealed by the State Seed Inspector when received by us. We in turn place our tag on the smaller lot to you sealing it in the same manner with the data showing the lot purchased. If you purchase full bag lots, the state seal tag accompanies shipment. This seed has a purity of 99.50 or better, is free of noxious weeds and sweet elover.

State Certified Red Tag-Genuine Grimm Alfalfa having a purity of 99.00 or better, noxious weed free, and containing not more than one-sixteenth of $1 \%$ of sweet clover.

Grower's Affidavit-This Grimm Alfalfa seed has not been inspected by state officials, but the grower supplies us with an affidavit tracing the source of his seed and that it is genuine Grimm Alfalfa.

\section{Sow Your Alfalfa with a WILL-BO SEEDER}

The Wil-Bo Seeder is made of best quality tin, with a 27 -inch tube, to which is attached a heavy drill bag. At the upper end of the tube is a regulator which is graduated to measure the amount of seed being sown. The bag is carried over the left shoulder by a heavy strap and the tube held in the right hand, swinging it at a low angle to permit the seed flowing from the end of the tube. By throw. ing the seed to cover 3 rods at a round, the rate of seeding is accurately measured. It works in windy weather as well as in good, and an operator can cover from 40 to 60 acres a day. The Wil-Bo will seed all clovers, alfalfa, bluegrass, timothy, and other small grass seeds. Price, Postpaid, $\$ 1.40$ each.

\section{Common Alfalfa} ing varies from 8 to 12 lbs. per acre. for prices.

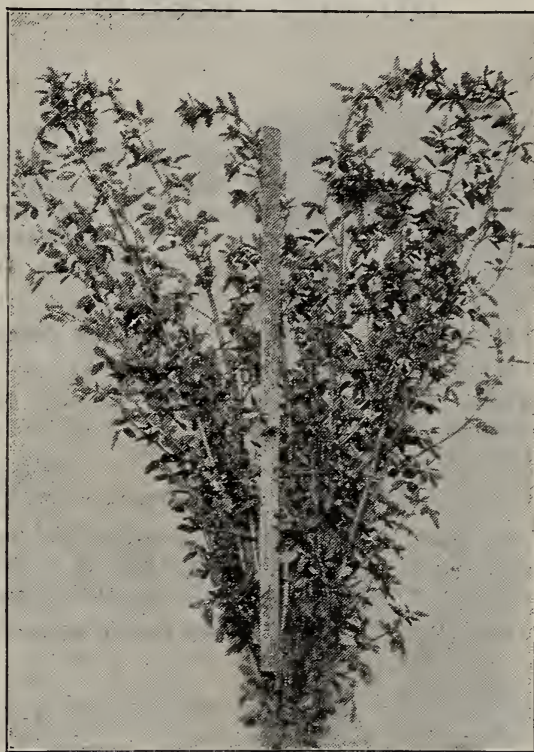

Grimm Alfalfa

HARDY UTAH-IDAHO COMMON ALFALFA-OUY common alfalfa seed is secured from the higher elevations of Utah and Idaho and is very hardy. This seed is sometimes not as fancy in color as south western grown seed, but it will produce the best crop and should always be used. The rate of seed-

Supreme Grade. Ideal Grade. See insert sheet

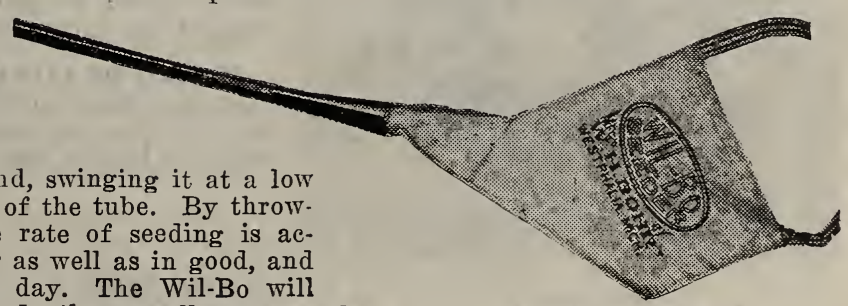




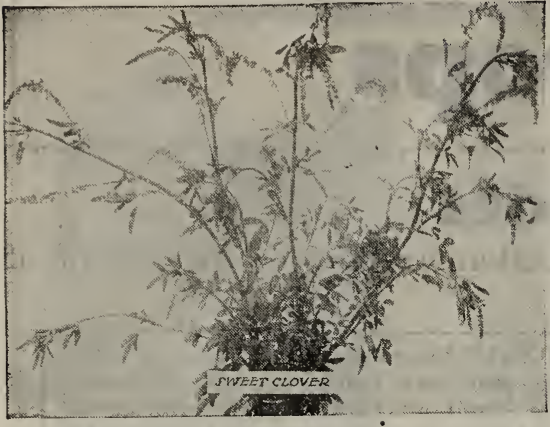

BIENNIAL YELLOW SWEET CLOVER -A variety with finer stems and more spreading in habit of growth. It bloums during the second year about two weeks earlier than the white variety. The flowers are yellow in color.

SUPREME-See insert sheet for prices. OUR SWEET CLOVER SEED IS SCARIFIED WHEN NECESSARY.

\section{Sweet Clover}

Sweet Clover is one of the best erops for soil improvement and in addition will supply pasture and hay. It grows well on irrigated land and will withstand drouth on non-irrigated areas. It can be sown with a nurse crop of peas or may be sown alone as early as conditions permit in the spring.

It is possible to furnish continuous pasture with sweet clover, if an area is seeded each spring. The old seeding can be pastured from May until the dry portion of the summer and then the new seeding pastured until late fall.

In some localities it is difficult to secure a good stand of alfalfa and many are reporting success, seeding a mixture of sweet clover and alfalfa seed. The alfalfa becomes established by the time the sweet clover is gone.

BIENNIAI, WHITE SWEET CLOVER-This variety grows to a height of 6 or 7 feet during the second season, bearing white flowers. It is desirable for hay or pasture during the first season, but must be eut when not over 30 inches tall the second year to produce a good quality of hay. A high stubble must be left after the hay is cut the second year, as the late growth starts from buds on the old cut stems rather than from the crown as in the case of alfalfa.

SUPREME-IDEAL. See insert sheet for prices.

Clovers

MAMMOTH RED-Similar in growth to the medium red clover, but larger and later in maturity. It reaches the best stage for hay along with timothy. We suggest a mixture of $6 \mathrm{lbs}$. clover to $10 \mathrm{lbs}$. timothy. The seed of this variety cannot be distinguished from that of the medium red clover.

SUPREME-See insert sheet for prices.

MEDIUM RED CLOVER-A variety most generally grown in mixture with other grasses for hay. If sown alone, 8 to $12 \mathrm{lbs}$. of seed is used, while in mixtures 4 to 6 lbs. is the usual rate.

\section{SUPREME-IDEAL-See insert sheet for prices.}

ALSIKE CLOVER-An excellent clover for low land. May be sown alone at the rate of $6 \mathrm{lbs}$. per acre or in mixture with timothy, red top and meadow fescue.

SUPREME-IDEAL-See insert sheet for prices.

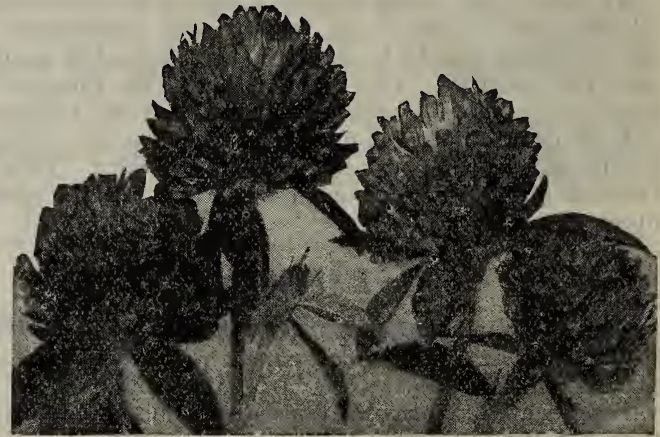

Mammoth Red Clover

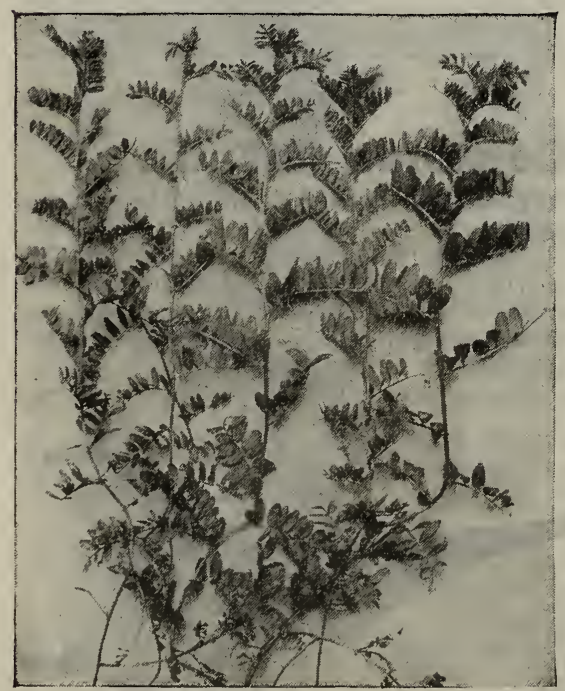

Vetch

WHITE DUTCH CLOVER-Used principally for lawn seeding, but often used in mixtures for irrigated pastures. The usual rate of seeding in pasture mixtures is 2 to $4 \mathrm{lbs}$. per acre.

SUPREME-IDEAL-See insert sheet for prices.

\section{Vetch}

WINTER OR HAIRY VETCH-A fine legume for poor land for soil improvement. It is often grown in mixture with winter wheat or fall rye for hay or pasture, and planted alone as a cover crop for orchards. If sown alone, 30 to $40 \mathrm{lbs}$. are used per acre, or in mixtures with fall grain using one bushel of grain to $25 \mathrm{lbs}$. of vetch. The grain erop aids in supporting the vetch vines. More vetch should be grown for seed purposes on the lighter timber soils of the northwest.

SPRING OR COMMON VETCH-This vetch produces larger seeds than the winter variety and should be planted in early spring, using 40 to $50 \mathrm{lbs}$. per acre. It makes a fine fertilizer crop and can be used for hay or pasture as well.

\begin{tabular}{|c|c|c|c|}
\hline & & rices & Frt. Extra \\
\hline & 11 & $10 \mathrm{lbs}$. & $\begin{array}{l}100 \mathrm{lbs} \text {. } \\
\$ 17.00\end{array}$ \\
\hline nter V & 20 & $\$ 1.75$ & $\$ 17.00$ \\
\hline
\end{tabular}




\section{Rape}

DWARF ESSEX-Rape is used for hog and sheep pasture, making a rapid growth of succulent feed. It is quite hardy and withstands frost. It is sorn in early spring and also late summer, planting in rows to permit cultiration or sown broadcast. From 5 to $12 \mathrm{lbs}$. of seed is required per acre, depending upon the method of seeding.

Dwarf Essex

Postpaid Prices

$1 \mathrm{lb} . \quad 10 \mathrm{lbs}$. $20 \mathrm{c} \quad \$ 1.75$

\section{Sunflowers}

Sunflowers may be used as a silage crop at higher elevations than corn, as they withstand more frost. Experiments show that the quality and feeding ralue of the silage is comparable to that made from well matured corn. Under similar conditions sunflowers will outyield corn, but are somewhat more expensive to harrest. Sunflowers, when grown for silage, may be drilled thickly in the row by the use of a grain drill. stopping up the drills to permit cultiration of the crop. Thes may be sown with a corn planter, spacing the plants from $\delta$ to 10 inches in the row. If a seed crop is desired the plants should be spaced at least two feet in the row.

MAMMOTH RUSSIAN-One of the largest rarieties with a heavy growth of leaves and large heads. The seeds are striped with black and gray color.

\begin{tabular}{|c|c|c|c|c|}
\hline & & Pos & Prices & Frt. Extra \\
\hline Mammoth & Russian & $\begin{array}{l}1 \mathrm{lb} . \\
20 \mathrm{c}\end{array}$ & $\begin{array}{l}10 \text { lbs. } \\
\$ 1.80\end{array}$ & $\begin{array}{l}100 \text { lbs. } \\
\$ 15.00\end{array}$ \\
\hline
\end{tabular}

\section{Grasses}

TIMOTHY - d hay crop in demand by lumber camps for horse feed. It produces a good yield of hay on bottom lands where the drainage is good and a fair return on higher land. If sown alone, use $12 \mathrm{lbs}$. per acre and 8 to $10 \mathrm{lbs}$. in mixture with clorer.

SUPREME-IDEAL-See insert sheet for prices.

TIMOTHY-CLOVER MIXTURE-We offer a mixture of timothy with red or alsike clorer. This mixture contains from 2 to 5 per cent of clover and should be used on cut over-lands and in pasture seeding.

SUPREMIE-See insert sheet for prices.

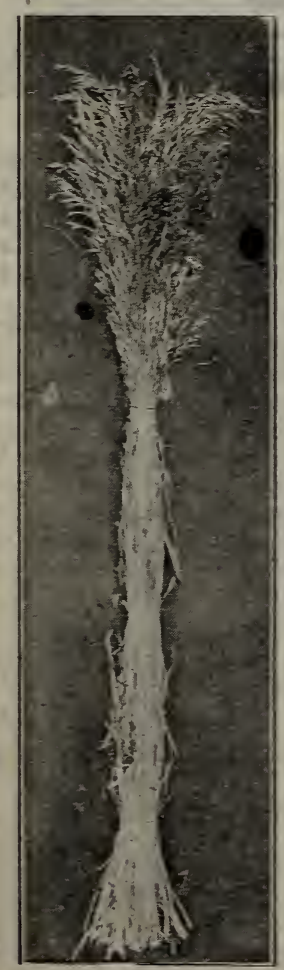

\section{Orchard Grasses}

ORCHARD GRASS-Orchard should be used in hay and pasture mixtures for dry lands as it is hardy, drouth resistant and long lired. It makes early spring and late fall pasture, growing in large leafy bunches. If somn alone, $14 \mathrm{lbs}$. is required per acre. We suggest a mirture of Orchard 5 lbs., Brome 5 lhs., and Slender Wheat 5 lbs. per acre for a permanent pasture on non-irrigated land, adding a few pounds of clover if a legume is desired.

\section{SUPREME-See insert sheet for prices.}

BROME-Brome is one of the most drouth resistant crops found for non-irrigated land. It is winter hardy, yields well, and the hay is rery palatable and nutritious. It makes a heary sod and stands tramping. It may be sown in mixtures with Orchard and Slender Wheat or in a mixture with alfalfa.

\section{SUPREME-See insert sheet for prices.}

RED TOP-A fine stemmed hardy grass for wet land. If sown alone 6 to 8 lbs. per acre are used. For a pasture mixture use 3 lbs. Red Top, 5 lbs. Timothy, 5 lbs. Meadow Fescue, and 3 lbs. Alsike ver acre.

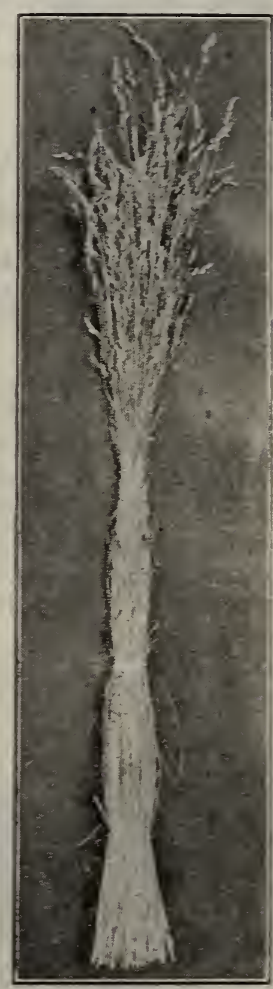

Orchard Grass

\section{SUPREME-See insert sheet for prices.}

MEADOW FESCUE-A rery hardy long lired grass growing well on wet land as well as drier soils. It makes excellent pasture or hay. It requires about $15 \mathrm{lbs}$. per acre when seeding alone or 5 to $8 \mathrm{lbs}$. in mixture with other grasses.

SUPREME-See insert sheet for prices.

SLENDER WHEAT-A native grass of the northern great plains and is rery drouth resistant. It grows in bunches, maturing with timothy. The plants are rery erect, leafy, and the heads small and slender of wheat-like appearance. From 12 to 15 lbs. per acre should be used when seeding alone or 5 to 10 lbs. in mixtures.

Brome Grass 


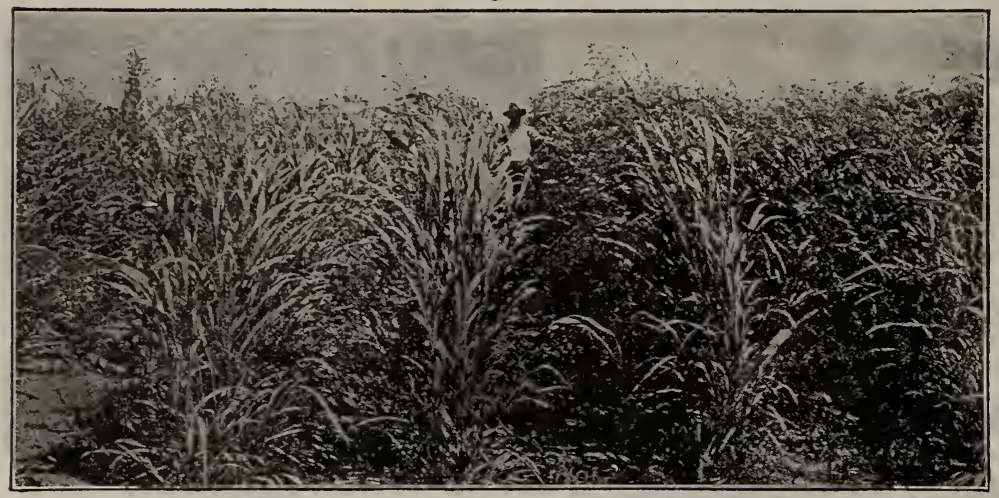

\section{Grasses- continued}

SUDAN GRASS - An annua: grass suitable as a catch cror in areas where the growing season is warm and entirely free of summer frosts. It may be drilled in rows wide enough apart for cultivation. This method requires $5 \mathrm{lbs}$. of seed per acre. If drilled for pasture or broadcast, from 25 to $30 \mathrm{lbs}$. are re quired.

SUPREME-See insert sheet for prices.

Sudan Grass

\section{Lawn Grasses}

The cost of lawn grass seed is a small item in establishing a lawn. If you purchase a cheap mixture, it is impossible to make a beautiful lawn. even though it is given the best of care.

We urge you to use Supreme Lawn Mixture or if you desire, a choice of the various grasses we offer, because they are of the quality which will produce the kind of lawn you can be proua of. It requires about $1 \mathrm{lb}$. of lawn grass to seed 400 square feet. We can assist you in working out a satisfactory mixture if you will write us.

KENTUCKY BLUE GRASS-One of the most popular grasses for lawns. It produces a heavy sod, is winter hardy, and grows well where plenty of moisture is available. May be used alone or in combination with Bent Grass and White Dutch Clover.

SOUTH GERMAN MIXED BENT-A mixture of Bent grasses used for golf greens and lawns. This grass stands shading and makes a very firm sod. The foliage is fine and velvety when kept clipped.

CHEWINGS FESCUE-A New Zealand grass of fine grayish green foliage, which is very tough and wiry. It is used in mixtures on golf fairways and on lawns subject to heavy wear. This grass must be clipped often and given an abundance of water so that it will retain its color and heavy turf growth.

WHITE DUTCH CLOVER--Should be used in mixtures for lawns in need of soil improvement. This clover is a long lived perennial and generally re-seeds sufficiently so that it increases yearly.

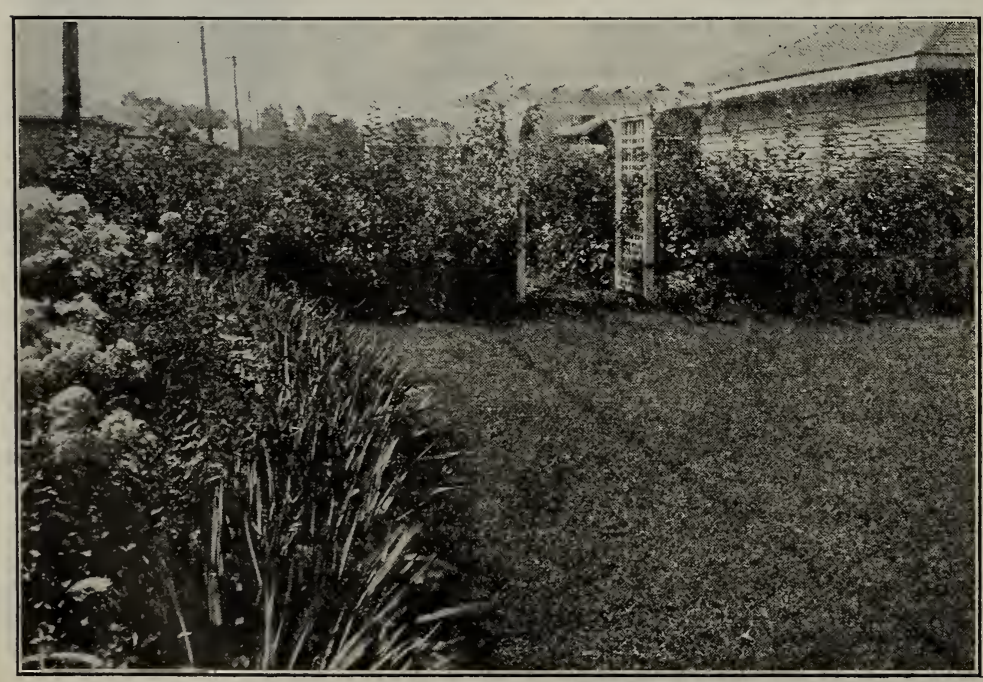

SUPREME LAWN MIXTUREThis is our own mixture developed after careful trials. We believe it best for general purposes, as it makes a fine velvety lawn that withstands hard use. It is composed of the grasses listed above, in the right proportion for best results. This mixture is made up from the best stock and does not contain chaffy seed.

Postpaid Prices

1-3 lb. 1 lb. 5 lbs. $10 \mathrm{lbs}$. Supreme Lawn

$\begin{array}{lllll}\text { Mixture } & . .25 c & 75 c & \$ 3.50 & \$ 6.50\end{array}$

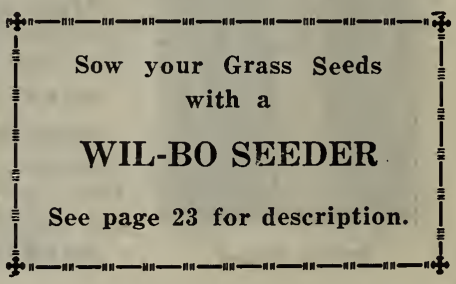




\section{Field Corn}

7 to $\&$ pounds of seed required per acre.

Our selection of corn rarieties is made to meet a wide range of growing conditions. Some of our corn is local grown, while the remainder is grown at the highest eleration possible to insure early maturity and vigor.

RESTLER White DENT-Our stock seed was secured from the Argonomy Department of the University of Idahe and was all selected for type and early maturity. This corn produces excellent yields of silage and matured grain is one of the earliest we offer.

NORTHWESTERN DENT-A fine corn for early hog feeding and for grain. The plants are dwarfed and the ears borne very close to the ground. The grains are red with yellowish white caps.

THAYER YELLOW DENT-This local yellow variety was selected by the Farm Crops Department of the Washington State College and is very early, producing large ears of good depth of grain. It is a good rariety for silage as well as mature grain.

MINNESOTA NO. 13-A familiar rariety dereloped in the northern part of the corn belt. It is hardy, producing a good leaf growth. The ears are medium in size with - deep jellow grains. It is not as early as Rustler nor Thayer but matures in an arer. age season at elevations of 2500 feet.

PRIDE OF THE NORTH-For a heary yield of silage, this variety is one of the best, but requires a longer season to mature than Thayer. The ears are larger than Minnesota 13 with a greater depth of grain.

REID'S YELLOW DENT-We hare found this variety does well in the irrigated sections where the growing season is long and the weather hot. It will not mature at elerations abore 2000 feet, but might be used for succulent late summer feed. The ears are long, with light lemon jellow grains.

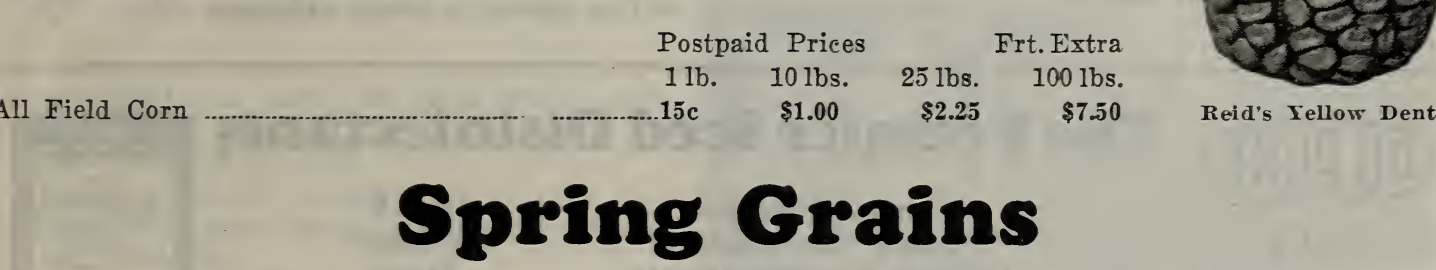

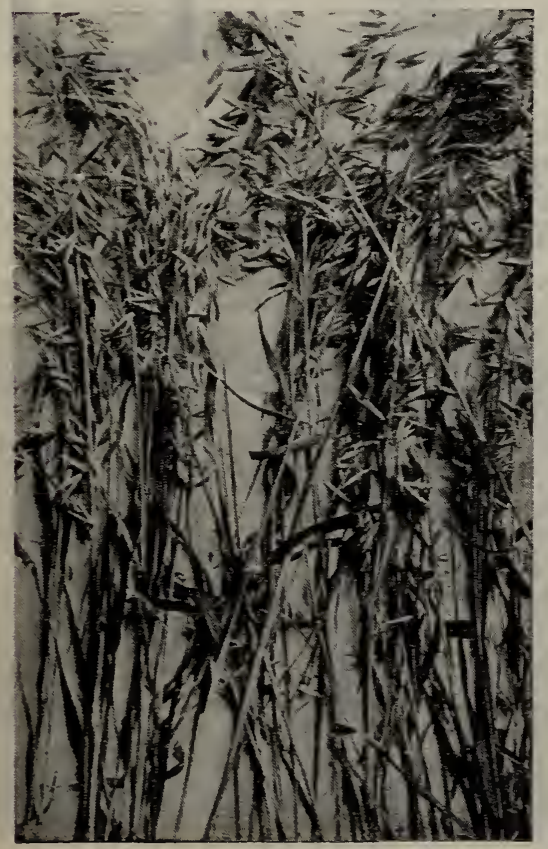

Markton Oats

See insert sheet for prices on all grains.

\section{Wheat}

If you are interested in spring wheat varieties, write us stating the variety and quantity you need and we will be pleased to sample and quote you prices.

\section{Oats}

MARKTON-A smut resistant white variety which has given fine vields throughout the irrigated as well as the non-irrigated sections of the Northwest. The grains have a thin hull, are long and contain a large kernel, with few double grains.

\section{Flax}

FLAX is grown to a limited extent throughout the Northwest for grain. In western Oregon, the crop is grown for fiber. It should be planted on land free of weeds, seeding after frost danger is past, sowing about 30 lbs. per acre.

\section{Barley}

WHITE HULLESS-Our stock of white hulless barley is local yrown, free of mixture and of fine quality. It is an excellent crop for hay as well as grain.

BEARDLESS-Beardless barley matures early and is desired by many for hay. It can be grown with peas or other grain for silage. 


\section{Grains-continued}

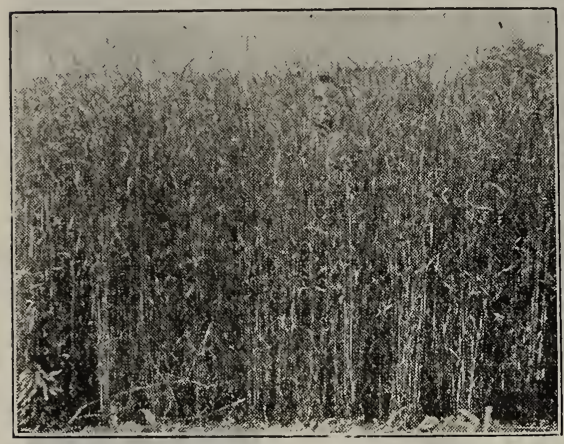

Rye

ROSEN RYE-A very winter hardy fall variety for grain. It is often planted in the spring for pasture. Some growers are sowing about 20 to 30 lbs. of rye with sweet clover to reduce the chance of bloat in livestock and to increase the feeding value of their pasture.

SPRING RYE-It is similar to the winter variety, making a mature grain crop when spring sown. The straw is not as heavy as in the winter rye and the grains are smaller in size.

\section{Field Peas}

All of our peas are thoroughly fumigated and cleaned to remove weevil and are put up in excellent conditions for seed. You cannot afford to plant seed that is not treated and properly cleaned.

ALASKA-An early maturing pea with slender vines growing to a height of 2 feet. The pods are straight, blunt, and well filled, all maturing at about the same time. The seed is smooth, round, dimpled, and of light blue color.

BLUE BELL-The plants of this pea are more stocky in habit of growth and later than the Alaska. The pods are larger and produced in clusters toward the top of the plant. The seeds are large, smooth, and of light blue color.

WHITE CANADA-A fine variety for commercial peas as they yield well and produce a small, smooth yellow seed of good quality.
WHITE MARROWFAT-A taller late pea with very large white seed.

MIXED PEAS-If you are in need of inexpensive pea seed for hog pasture or stock feed, these peas. will meet your requirement. They are a mixture of smooth and wrinkled peas, carefully cleaned and fumigated and will give you as good a return as high priced seed for the above purpose. See insert sheet for prices.

\section{Field Beans}

If you need a new stock of field bean seed, write us as to the variety you want and the quantity, we will be pleased to sample and quote you.

\section{TIVIVT The Premier Seed Disinfectants}

SEMESAN

SEMESAN JR. SEMESAN BEL

\section{Control Diseases Hasten Germination \\ Produce Sturdier Plants \\ Increase Crop Yields Improve Quality}
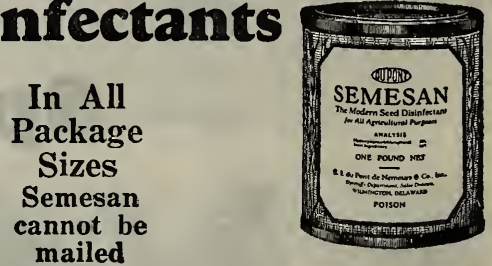

\section{Opinions of Experienced Users}

Semesan is recognized by the U. S. Department of Agriculture and the Green Section of the U. S. Golf Association as the best fungicide for preventing and curing both large and small "Brown Patch" of grasses.

In Southern Idaho, Semesan-treated beans, with their 20 to $40 \%$ increased yields, so convinced prominent growers that they unite in saying they: "will always use Sem
treating bean seeds, as well as their other crops."

Florists write us such tributes as: "We used Semesan on poinsettia cuttings last summer with excellent results"; and

"My Semesan-treated aster seeds gave an almost perfect "My Semesan-treated aster seeds gave

The U. S. Department of Agriculture's Circular No. 376 recommends treatments with Semesan as the most successful means known for preventing and controlling the "Crown Gall" disease of apple grafts.

The U. S. Department of Agriculture, in collaboration with the Illinois and Iowa State Experiment Stations, demonstrated that Semesan $\mathrm{Jr}$. was a most effective dust disinfectant for controlling the diseases and increasing the yields obtained from infected field and sweet corn seeds.

The Idaho Agricultural Experiment Station reported that Semesan Bel: "- -when applied to the uncut presprinkled tubers (potatoes) at the rate of three ounces to the bushel gave better control under field conditions than any other treatment tested."

SEMESAN-This modern disinfectant can be applied in either the liquid or convenient dust form to prevent or control effectively a most diversified variety of parasitic diseases and fungoid growths borne by seeds, seed pieces, plants, grafts and soils. Semesan is harmless to seed and plant life but extremely poisonous to disease and fungous organisms. It generally also hastens cermination, produces sturdier plants, promotes earlier maturity and increases both the plants, promotes earlier maturity

SEMESAN JR.-A less expensive but equally effective form of Semesan for the dry dust disinfection of both field and sweet corn seeds against the ear, root and stalk rots. Under Government-conducted field tests, with Diplodia and Gibberella infected seeds. Semesan Jr. successfully prevented or controlled these diseases and at the same time increased the yields from 10 to over $40 \%$

SEMESAN BEL-Applied to whole or cut seed potatoes, either as a dry powder or a whitewash-like water mixture, either as a dry powder or a whitewash-like water mixture, potato diseases. In widely separated potato-growing sections it has caused quicker sprouting, earlier maturity and greater it has

\section{F. O. B. Moscow-Express Charges Additional}

Prices for Du Pont Semesan

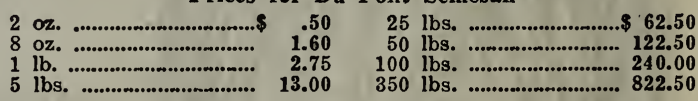

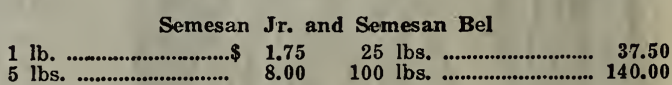




\section{Ornamental Shrubs}

Every farm home should include a planting of shrubs. They are inexpensive and ard to the attractireness of the surroundings. Our offering of shrubs are varieties that are hardy and will grow in nearly any loeation if moisture is supplied during the dry part of the season. They are large, healthy, and well rooted and we know that you will be pleased with them. Prices F. O. B. Moscow, shipments made on all early orders as soon as meather conditions permit. Place your order early.

ALMOND-A beautiful shrub producing a profusion of small rose-like flowers, desirable for individual planting. Choice of pink or. white. Each, $\$ 1.25 ; 2$ to 3 feet in height.

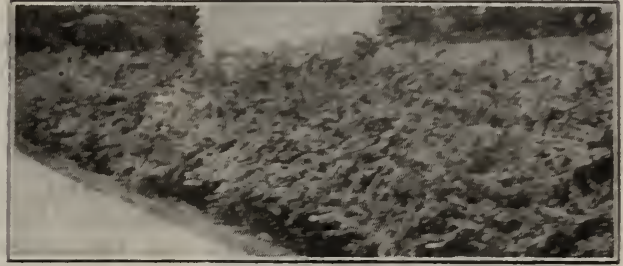

Japanese Parberry

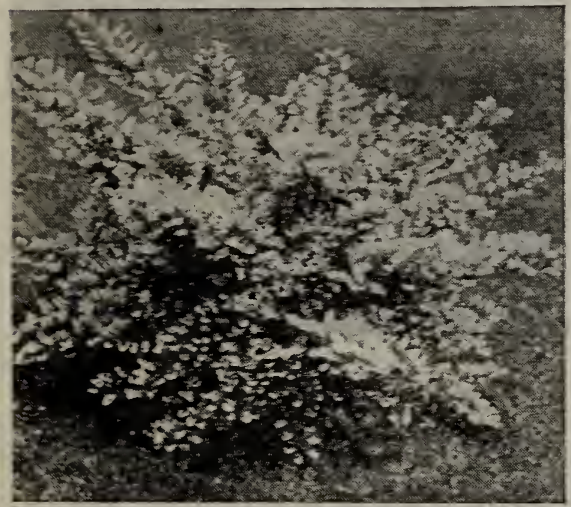

Deutzia

BUDDLEIA (Butterfly Bush) - A summer-flowering shrub with riolet colored flowers. Each, 75c.

ALTHEA-Rose of Sharon, a late blooming shrub with large Hollyhock type flowers. Choice of white, red, and pink. Ea. 75c.

BARBERRY-We offer the Japanese, of dwarf habits of growth, with fragrant vellow flomers and bright red berries. An excellent shrub for hedges and border planting. Each, 50c, 12 to 18 inches tall.

CARAGANA-The large pea-like flowers are rellow in color and the foliage bright green in color. Each, 50c, 3 to 4 feet in height.

DEUTZIA-A choice shrub for group planting, mid-season in bloom.

Pride of Rochester-Iarge white flowers, tinged with pink. Candisissima-Flowers pure white.

Crenata Rosea-Deep rose-colored flomers.

Each, $75 \mathrm{c}$, large rigorous plants.

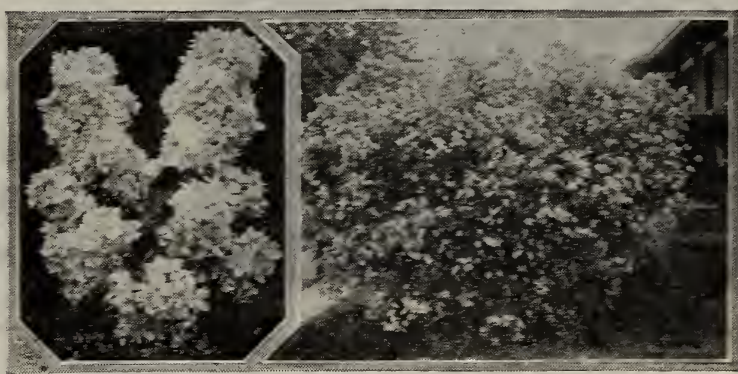

Lilace

MOCK ORANGE-The Idaho State Flower. Very hards, with orange-like flowers of wonderful fragrance. Each, 75e.

COTONEASTER-An erect semi- erergreen shrub with white flowers, followed by showy red berries. Each, 75c.

CRAB (Bechtel's Flowering) - A shrub-like tree with fragrant pink flowers, blooming when quite roung. Each, $\$ 1.00$.

CYDONIA (Japan Quince)-Blooms before the leares appear. The flowers are large, of scarlet color. Ea. 75c.

HONEYSUCKLE (Bush)-The Pink Tartarian honeJsuckle is desirable for its early flowers, following by red berries. Each, 75 c.

HYDRANGEA-Paniculata, a half-hards shrub with large clusters of pure white flowers changing to pink. Each, $\$ 1.00$.

PRIVET-One of the best plants for hedge planting. $25, \$ 3.00 ; 50, \$ 5.50 ; 100, \$ 10.00$.

ROSE ACACIA-A beautiful shrub with showy pealike flowers. Plants are very hards. Each, \$1.00.

RUSSIAN OLIVE-A shrub-like tree with silrery gray leares. It should be used in group planting for rariety or planted singly. It can be trained for hedges by proper spaeing and trimming. Each, 50c. 


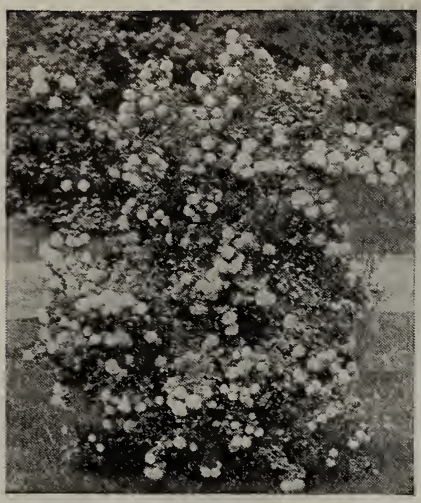

Snowball

\section{Ornamental Shrubs-continued}

SNOWBALLS-Well grown shrubs with large, ball-like mass of white flowers.

HIGH BUSH CRANBERRY - A very ornamental variety. The flowers are followed by cranberry like fruits. Each, 75c.

SNOWBERRY-A fine shrub for shady locations. It produces large snowwhite berries in early fall. Each, 75c.

SPIREA-One of the most desirable shrubs for banking at the corners of buildings, with long branches and masses of beautiful flowers.

Anthony Waterer-Compact and low growing for use in front of taller shrubs. Bright pink flowers.

Billardi Rosea-Erect in growth, pink flowers. Each, 75c. Opulifolia (Ninebark)-Good for borders, white flowers.

Opulifolia Aurea-Foliage a bright golden color.

Van Houttei-Beautiful white flowers, very popular. Ea. 75c.

TAMARIX (Gallica)-Fine for group planting, has a filmy foliage, and pink flowers. Each, 75c.

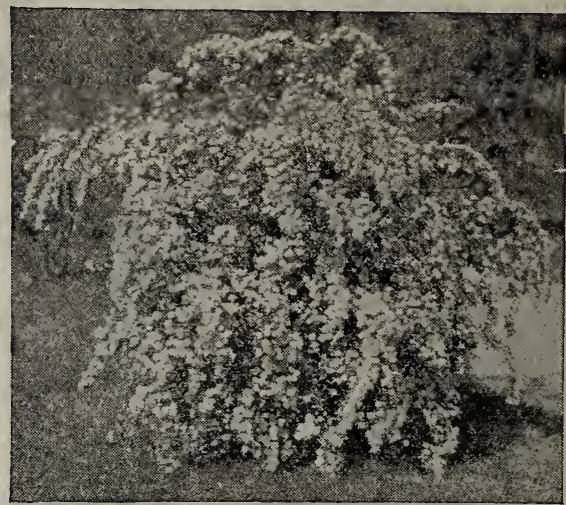

Spirea Van Houttei

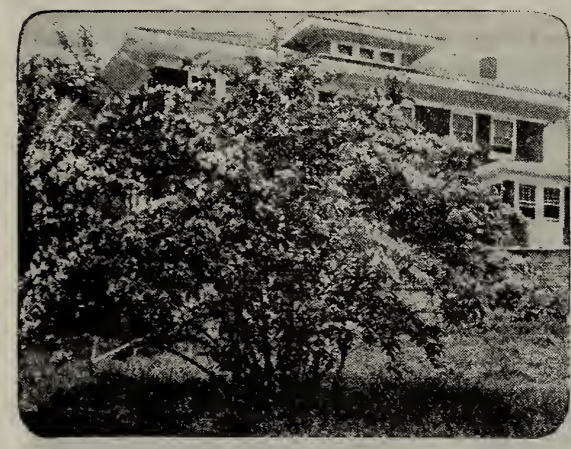

Weigelia

WEIGELIA-A border plant with large trumpet-like flowers. Candida-Has white flowers, blooming throughout the summer.

Rosea-Flowers of rose color. Each, 50c.

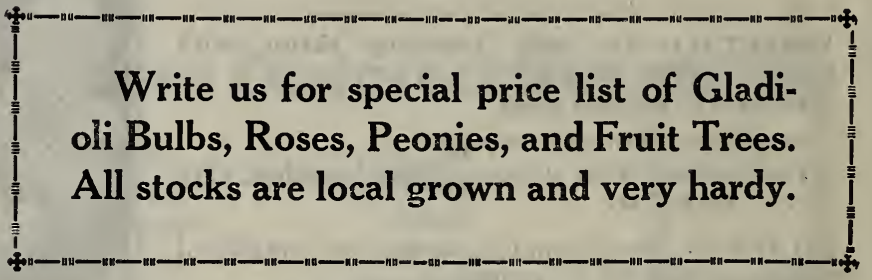

\section{Hardy Climbing Vines}

VIRGINIA CREEPER-A rapid grower, leaves turning to red in early autumn. Each 50c. Large, vigorous plants.

ENGELMAN CREEPER-A fine vine for rock or brick walls. as it clings tightly to the erevices. Each, 50c. Large plants.

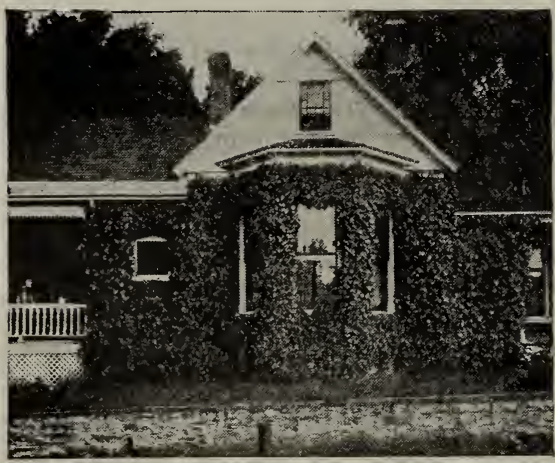

TMPET VINEA showy vine with large trumpet flowers of orange scarlet color. Each, 75c.

CLEMATIS (Paniculata) -- Sweet autumn variety with white flowers. Each, 75c.

See Special Flower Collections on inside of back cover.

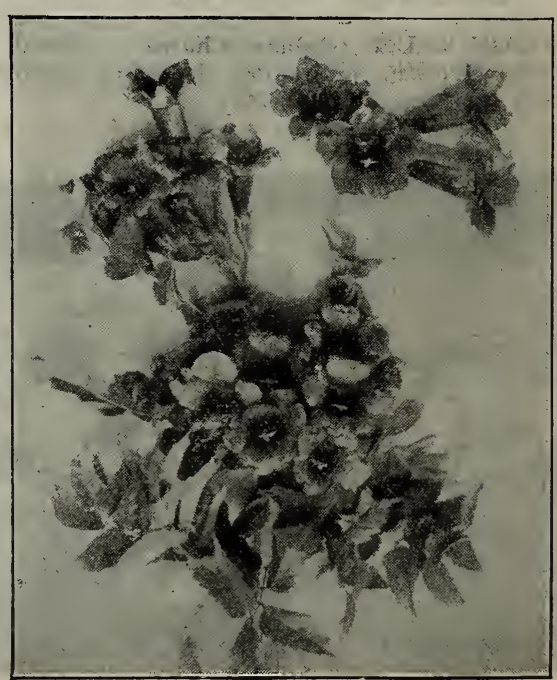

Trumpet Vine 


\section{Incubators and Brooders}

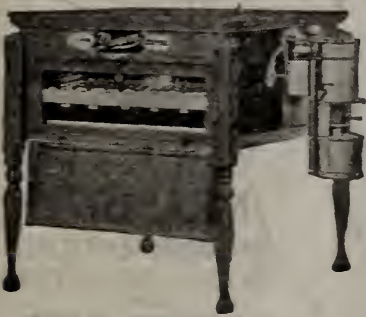

Vo. \& staindar

Style

20-K

$21-\mathrm{K}$

22-K

No. 1

No. 2

No. 3

No. 4

No. 5

No. 25

No. 30

No. 40

No. 50

No. 32

No. 42

No. 52

No. 0

No. 1

No. 2

No. 4
Capasity

Capacity

i0.egg.

2:20-egg.

85 -egg.

135-egg.

150-egg.

275 -egg.

400-egg.

600 -egg.

800 -egg.

1000 -egg.

1500 -egg.

\section{OIL BROODERS}

300-chick

600 -chick

1200-chick

\section{COAL BROODERS}

400 -chick

800 -chick

1200-chick

1600 -chick Mammoth

\section{EXTRAS AND REPAIRS}

Prices F. O. B. Moseom

$\$ 18.00$

30.75

40.50

30.50

41.00

48.25

62.50

73.75

.116 .00

174.00

217.00

325.00

$\$ 17.25$

20.25

22.25

$\$ 18.00$

23.75

29.50

35.00

"R" and Brooder Stores

Postpaid

$\$ 10.75$

Wafers, 3 inch for " $\mathrm{K}$ " and Brooder Stores. 1.00

Thermometers, Incubator 1.00

Thermometers, Brooder

Combination flue for incubator

Lamp Complete for " $\mathrm{K}$ " Machine (state size and model)...

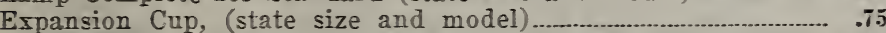

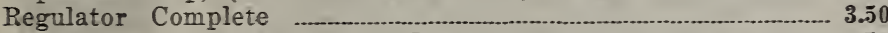

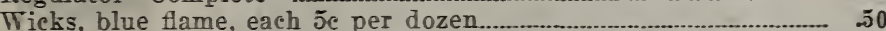

Write us for prices on other repairs.

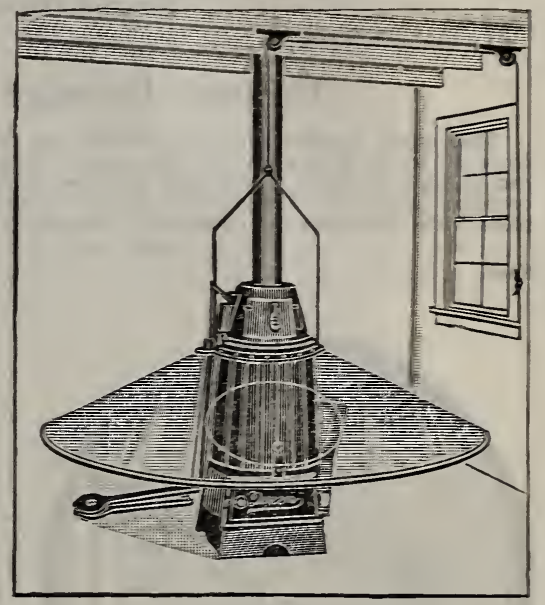

Brooder Store

IF YOU WANT A MAM-

MOTH INCUBATOR, THE QUEEN HAS IT

Sizes 1600 to 43,000 egg capacity.

\section{Suggestions as to Orders}

HOW TO SHIP-Write your name, postoffice, state and railroad plainly on each order. If a portion of your order is to be shipped by freight or express, give us careful in-

structions as to shipping point.
USE OUR ORDER SHEET-You will find an order sheet inclosed in this catalog for your use. Be careful to state the variety as well as the kind of seed desired. Check the prices quoted with the seeds ordered after completing your list of quoted with the seeds ordered after completing your list of requirements. Keep a copy of your order for your own reference, so that shipment can be checked upon its receipt.
TERMIS-Personal checks, money orders, drafts mas be sent in payment of orders. In case of small purchases, stamps may be submitted. In case of freight or express orders, payment of transportation in advance is necessary if there is no agent at your shipping point.

ERRORS-We take the greatest care possible in filling or-

ders. In case of mistakes in filling orders, please notify us, giving details, as we want all orders correct.

In some instances, it is necessary to "back order" an item which is temporarily out of stock. You will find notice of this omission with your order as receired. These back orders are filled at the earliest possible time.

PARCEL POST-Small shipments of seed are sent parcel post. The reight limit in zones 1,2 and 3 is $70 \mathrm{lbs}$., which must include weight of container as well as merchandise. In zones 4 and 5 , the weight limit is $50 \mathrm{lbs}$.

Poisons, such as lead arsenate, Paris Green, etc., cannot be sent through the mails and must be sent by express.

To take advantage of the 5 or $10 \mathrm{lb}$. rate on peas, beans and sweet corn, you may select one or more variety. Always allow an additional pound on the postage rate for containers.

Parcel Post Zone Rates

$$
\text { 1st and 2nd Zones }
$$
1 to 150 miles

7 cents for first lb., 1 cent each additional ib. $70 \mathrm{lb}$. limit

\section{3rd Zone \\ 150 to 300 miles}

8 cents for first $1 \mathrm{~b}$., 2 cents each additional Ib.

$70 \mathrm{lb}$. limit
4 th Zone

300 to 600 miles

9 cents for first Ib., 4 cents each additional Ib. $50 \mathrm{lb}$. limit 5th Zone

600 to 1000 miles

10 cents for first Ib., 6 cents each additional Ib. 50 lb. limit 


\section{The Patterson \& Young Incubator Moisture Guide}

A scientific, practical and reliable instrument for recording the evaporation in your incubator. Tells when to add moisture or give more ventilation. It shows the accumulated evaporation in the machine, enabling the operator to properly control moisture conditions. Attachments are included for all turning trays. Complete with directions.

Each

Postpaid Prices

$\$ 1.00$

\section{Little Putnam Stoves}

A fire-safe stove for keeping the poultry drinking fountain from freezing in cold weather. Stove holds $31 / 2$ pints of oil and burns a month without refilling. Suitable for use as an oat sprouter as well. Complete directions for operation and use. Weight, 2 lbs.

Postpaid Prices

.$\$ 2.00$

\section{Putnam Brooder Heater}

This small brooder heater is suitable for brooding a small flock of chicks, from 80 to 50 chicks of the same age. With this stove and directions you can build a brooder, which will care for your chicks with less trouble than brooding with hen. Stove will burn for ten days with one filling of oil. Combrooding with hen. Stove will burn for ten days with
plete with directions for operation. Weight, 2 lbs.

Each Postpaid Prices

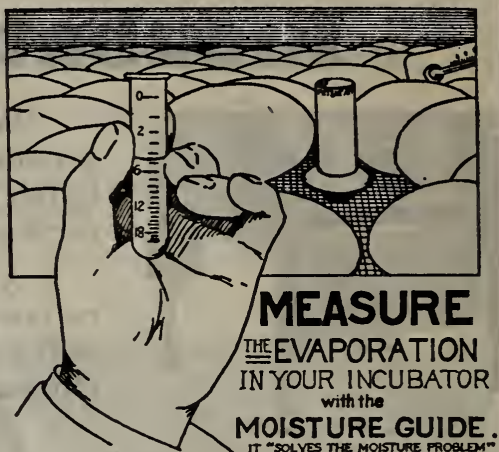

\section{Servall Float Fountain}

An automatic float which regulates the flow of water to fountain. Is easily attached to water feed pipe into poultry house and keeps fresh water coming into fountain as needed.

\section{Postpaid Prices}

Each $\$ 1.50$

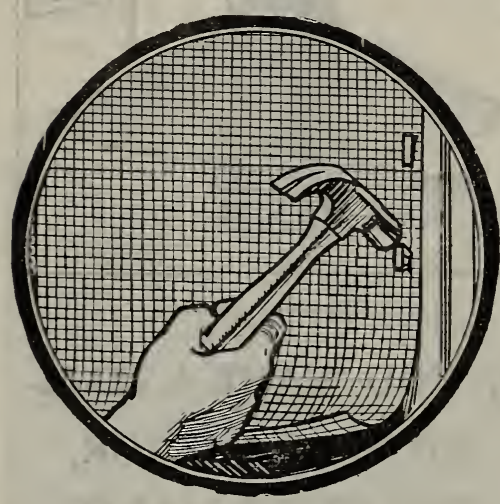

\section{Cel-0-Glass}

Cel-O-Glass is a light weight UNBREAKABLE material that admits light almost as freely as clear glass. It is hailproof, heatproof, coldproof, and weatherproof.

Cel-O-Glass is ideal for hotbed sash, cold frames, fronts. sides and interiors of greenhouses. barn windows, cellar windows, and other uses where glass is subject to strain or breakage. Frames made of Cel-O-Glass weigh only $10 \mathrm{lbs}$. and save time and labor in handling.

Cel-O-Glass lets through the health giving Ultra-violet rays of the sun which are so valuable in poultry raising. Ordinary glass absorbs these rays and does not let them pass through. Cel-O-Glass makes the chicks grow faster, lay more eggs and prevents "leg weakness."

Cel-O-Glass can be put on easily. A hammer, tacks, and an ordinary pair of shears are the only tools needed. Home-made frames may be used, thus reducing the cost of windows and sashes.

Cel-O-Glass comes in standard rolls 100 feet long by 3 feet wide and is as strong as screen wire, rustproof, and can be bent without danger of breakage. Try it yourself and you will find it very practical and a real economy.

Per running foot

Postpaid Prices

$50 \mathrm{c}$

\section{Cyan-0-Gas}

Many methods for the control of the Columbian Ground Squirrel have been tried with varying success. The best means today and the surest is the use of Cyan-O-Gas. This material is a product of Calcium Cyanide, especially prepared for this purpose. The only equipment you need is a long-handled spoon that will hold two ounces of the cyanide. Throw a spoonful of the cyanide into each burrow, covering the field thoroughly. Any burrows missed should be treated within a few days. The soil moisture combines with the material pro ducing a poisonous gas that kills all squirrels. Nearly one-half a million pounds has been used effectively in the Palouse.

Cyan-0-Gas can only be shipped by express or freight

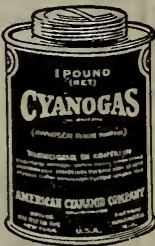

GRANULAR CYANIDE-Is used for the control in open burrows. This Cyanide is in small particles but not finely ground.

"A" DUST_A fine pulverized grade of Cyanide for use in dust guns. While " $A$ " Dust is more expensive than the granular form, when used in dust guns it will cover a larger area and is very effective.

Prices F. O. B. Moscow. Cannot he mailed SIZE CONTAINER $1 \mathrm{lb} .5 \mathrm{lbs} .25 \mathrm{lbs} .100 \mathrm{lbs}$.

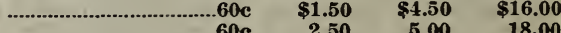

\section{Insecticides and Fungicides}

PARIS GREEN-A quick acting poison for the control of biting insects. Used 1 to $1 \frac{1}{2}$ lbs. of Paris Green to 50 gallons of water.

Half 1b. 40c; 1 1b. 75c. Not mailable

ARSENATE OF LEAD-In the dry powdered form, Arsenate of Lead mixes readily with water. Use 1 lb. to 50 gallons of water. Excellent for spraying fruit trees for codling moth and for the control of potato bugs.

1 lb. $45 \mathrm{c} ; 4$ 1bs. \$1.25. Not mailable

DRY LIME SCLPHCR-This form of sulphur is just as effective as the solution in the control of scale insects and fungous diseases.. Use 1 to $11 / 2$ lbs, to 50 gallons of water.

1 1b. 30c; 5 lbs. \$1.25; 25 lb. drum \$3.75. Not mailable BORDEAUX MITURE-A combined insecticide and fungicide. Use $8 \mathrm{lbs}$. to 50 gallons of water for a 4-4-50 mixture.

1 lb. 35c; 5 lbs. \$1.25; 25 1b. drum \$4.50. Not mailable

VOLCK-An ortho-spray composed of petroleum oils for the control of scale insects, mealy bugs, white flies, red spiders, and rust mites. It may be combined with lead arsenate, bordo-arsenate, and nicotine sulphate sprays. We recommend it highly for the above insects. Half pint $35 \mathrm{c} ; 1$ pint 50c; 1 quart 75c. Not mailable.

FERTILO WORM REPELLENT-An insect destroyer for use on radishes, turnips, onions, etc., for the control of root maggots.

Carton 30c. Not mailable

HILL'S NICOTINE SULPHATE-For the control of Aphis and other insects on roses, flowers, etc. 1 oz. will make 6 gallons of spray. 1 oz. 35c. Not mailable 


\section{Supplementary Price List Effective January 10, 1928 PRICES SUBJECT TO CHANGE}

Terms:-Cash with order, F.0.B. Moscow, Idaho. Bags iurnished iree, gross weight ior net WRITE US FOR QUANTITY PRICES

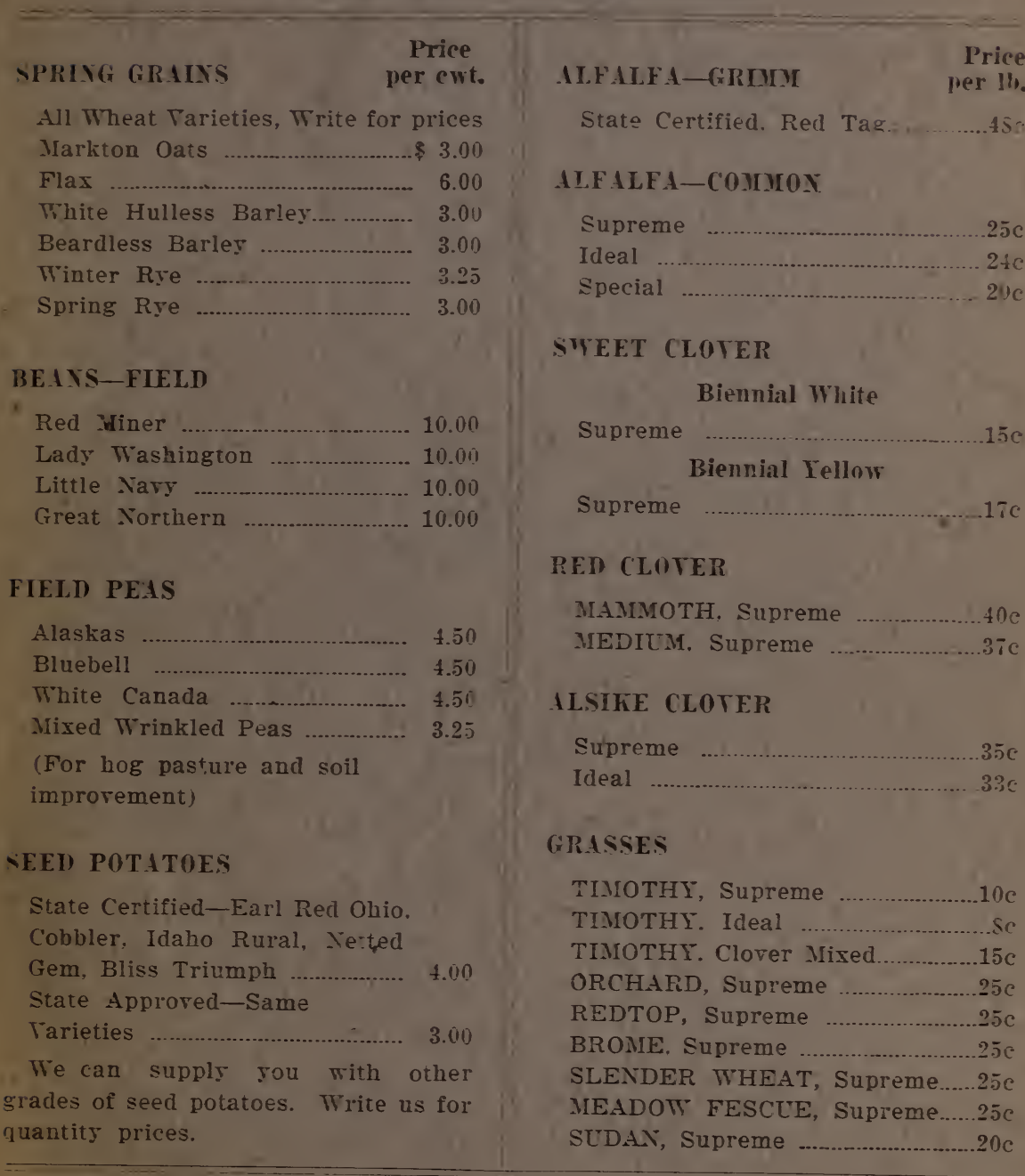





\section{Supplementary Price List Effective January 10, 1928 PRICES SUBJECT TO CHANGE}

Terms:-Cash with order, F.O.B. Moscow, Idaho. Bags iurnished iree, gross weight for net

WRITE US FOR QUANTITY PRICES

\section{SPRIYG GRAINS}

Price
per cwt.

All Wheat Varieties, Write for prices Markton Oats $\$ 3.00$

Flax 6.00

White Hulless Barley. 3.00

Beardless Barley 3.00

Winter Rre 3.25

Spring Rre $3 . i(j)$

\section{BEATS-FIELD}

Red Miner 10.00

Lady Washington 10.00

Little Nary 10.00

Great Northern 10.00

\section{FIELD PEAS}

Alaskas

Bluebell

4.50

White Canada

4.50

Mixed Wrinkled Peas 3.25

(For hog pasture and soil improrement!

\section{SEED POTATOES}

State Certified-Earl Red Ohio. Cobbler. Idaho Rural, Netted Gem, Bliss Triumph 4.60 State Approred-Same Varieties

We can supply you with other grades oi seed potatoes. Write us for quantity prices.

\author{
ALFALFA-CPRMI per th. \\ State Certified. Red Tag ............ $1 \mathrm{~S}$ \\ ALFALFA-COMMON \\ Supreme …_.................................25c

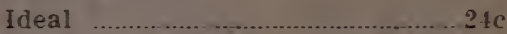

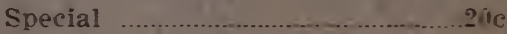

\section{STEET CLOVER}

Biennial White

Supreme ….............................

Supreme

\section{PED CLOTER}

MAMMOTH. Supreme ..................toc MEDIUM, Supreme ………...........37c

ALSIKE CLOTEP

Supreme

Ideal .............................................

\section{FPASSES}

TIMOTHY, Supreme ....................10

TIMOTHY. Ideal ...............................

TIMOTHY. Clover Mixed.................15c

ORCHARD, Supreme …………..... $25 \mathrm{c}$

REDTOP, Suporeme …................... $25 \mathrm{c}$

BPOME. Supreme ........................25c

SLENDER WHEAT, Supreme.....25c

MEADOW FESCUE, Supreme......25c

SUDAN, Supreme ….....................20 



\section{Supplementary Price List \\ Effective January 10, 1928 \\ PRICES SUBJECT TO CHANGE}

Terms:-Cash with order, F.0.B. Moscow, Idaho.

Bags furnished iree, gross weight ior net

WRITE US FOR QUANTITY PRICES

SPRIYG GRAIIS $\begin{gathered}\text { Price } \\ \text { per ewt. }\end{gathered}$

All Wheat Varieties, Write for prices Markton Oais $\$ 3.00$

Fiax

6.00

White Hulless Barley.

3.00

Beardless Barley

3.00

Winter Rre

3.25

Spring Rye

3.00

\section{BEAYS-FIELD}

Red Miner 10.00

Lady Washington ..................... 10.00

Little Nary ............................... 10.00

Great Northern ......................... 10.00

\section{FIELD PEAS}

Alaskas

Bluebell

White Canada

4.50

Mised Wrinkled Peas

3.25

(For hog pasture and soil improrement)

\section{SEED POTATOES}

State Certified-Earl Red Ohio. Cobbler, Idaho Rural, Netted

Gem, Bliss Triumph 4.00

State Approved-Same

Varieties

-

3.00

We can supply you with other grades of seed potatoes. Write us for quantity prices.

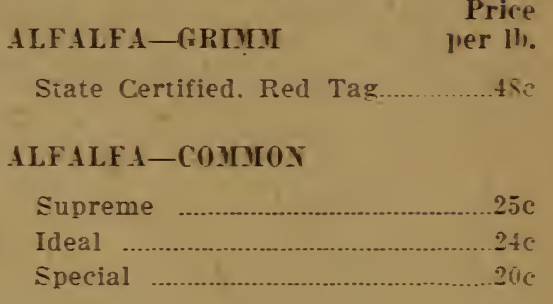

\section{SWEET CLOTER}

Biennial White

Supreme $15 \mathrm{c}$

Biennial Yellow

Supreme $1: c$

\section{RED CLOTER}

MAMмOTH. Supreme ....................40 MEDICM, Supreme ....................... 3 ic

\section{ALSIKE CLOTER}

Supreme $35 \mathrm{c}$

Ideal $33 \mathrm{c}$

\section{GRASSES}

TIMOTHY, Supreme .......................10

TIMOTHY. Ideal ............................... $\mathrm{se}$

TIMOTHY. Clover Mixed.................15c

ORCHARD. Supreme ......................25c

REDTOP, Supreme .......................5c

BRONE. Supreme ..........................25c

SLENDER WHEAT, Supreme......25c

MEADOW FESCLE, Supreme.....25c

SUDAN, Supreme 



\section{Washburn-Wilson Seed Co. Seed Growers--Seed Merchants \\ OMOSCOW, IDAHO}

Write Name and Address Plainly. Send Money With All Orders. No. C. 0. I. Shipments Send by - (State Whether by Mail

Name

Date.

Post Oîice

R. F. D. Street and No.

State

Shipping Station

Express Co. or Railroad.

Aniont Enclosed

P. 0, 0rder - . \$

Draît - - - -
Express Order -

Cash . . - \$

Stamps . . . \$

Total \$

County

Washburn-Wilson Seed Co. gives no warranty, expressed or implied, as to purity, description, quality, productiveness or any other matter of any seels, bulbs or plants they send out, and will nut be in any way responsible for the crop. If the purchaser does not accept the grods on these terms they are at once to be returned.

\begin{tabular}{|c|c|c|c|c|c|c|}
\hline 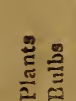 & 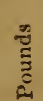 & 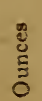 & 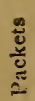 & $\begin{array}{c}\text { NAMES OF SEEDS AND OTHER } \\
\text { ARTICLES WANTED } \\
\text { (Please Use One Line for Each Item) }\end{array}$ & : & 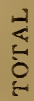 \\
\hline
\end{tabular}




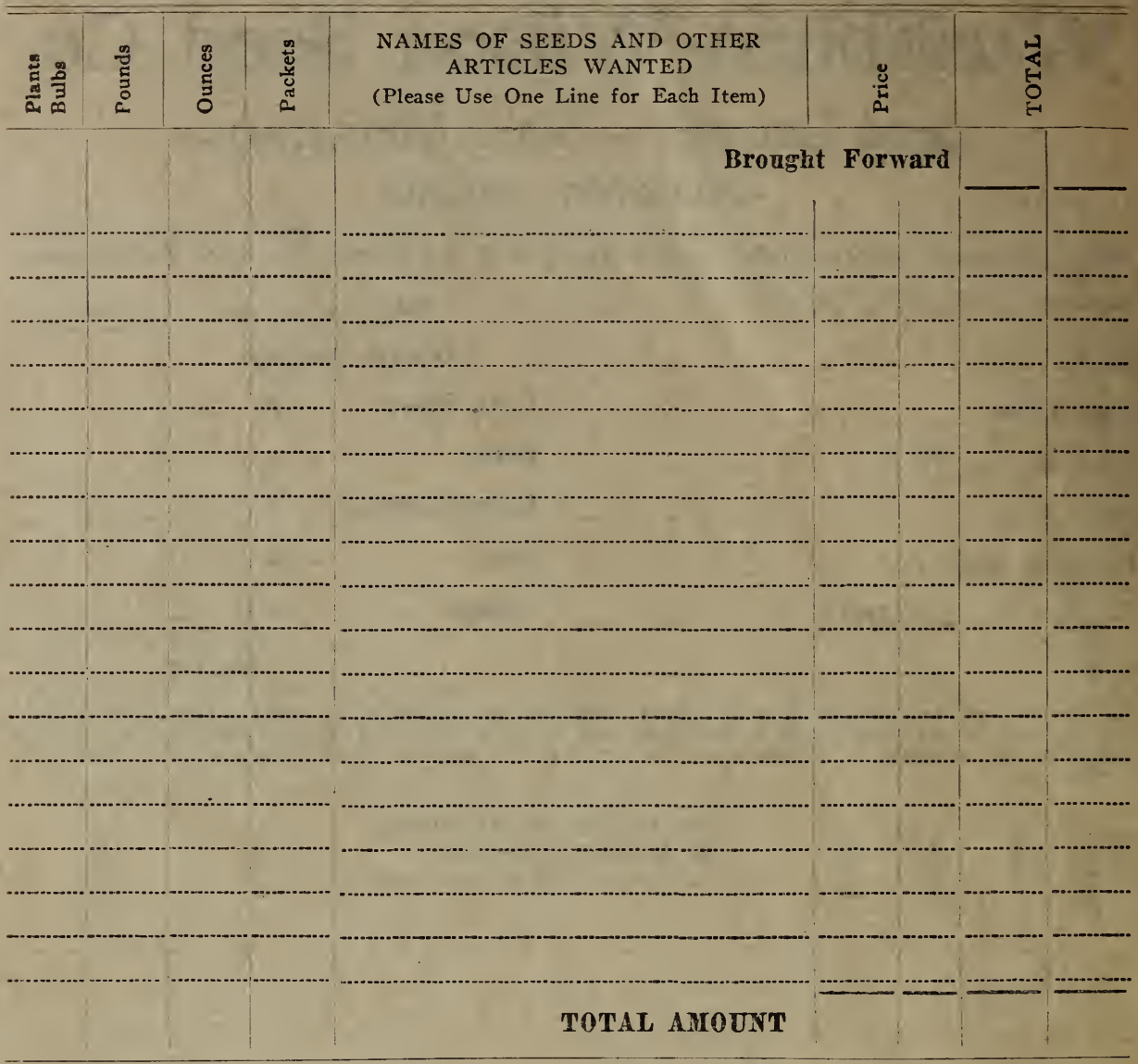

If you know of any farmers, market gardeners or others who are not receiving our catalog, please supply us with their names and addresses. Please use the head of the family only in your list.

NAME POSTOFFICE R.F.D. No. STATE




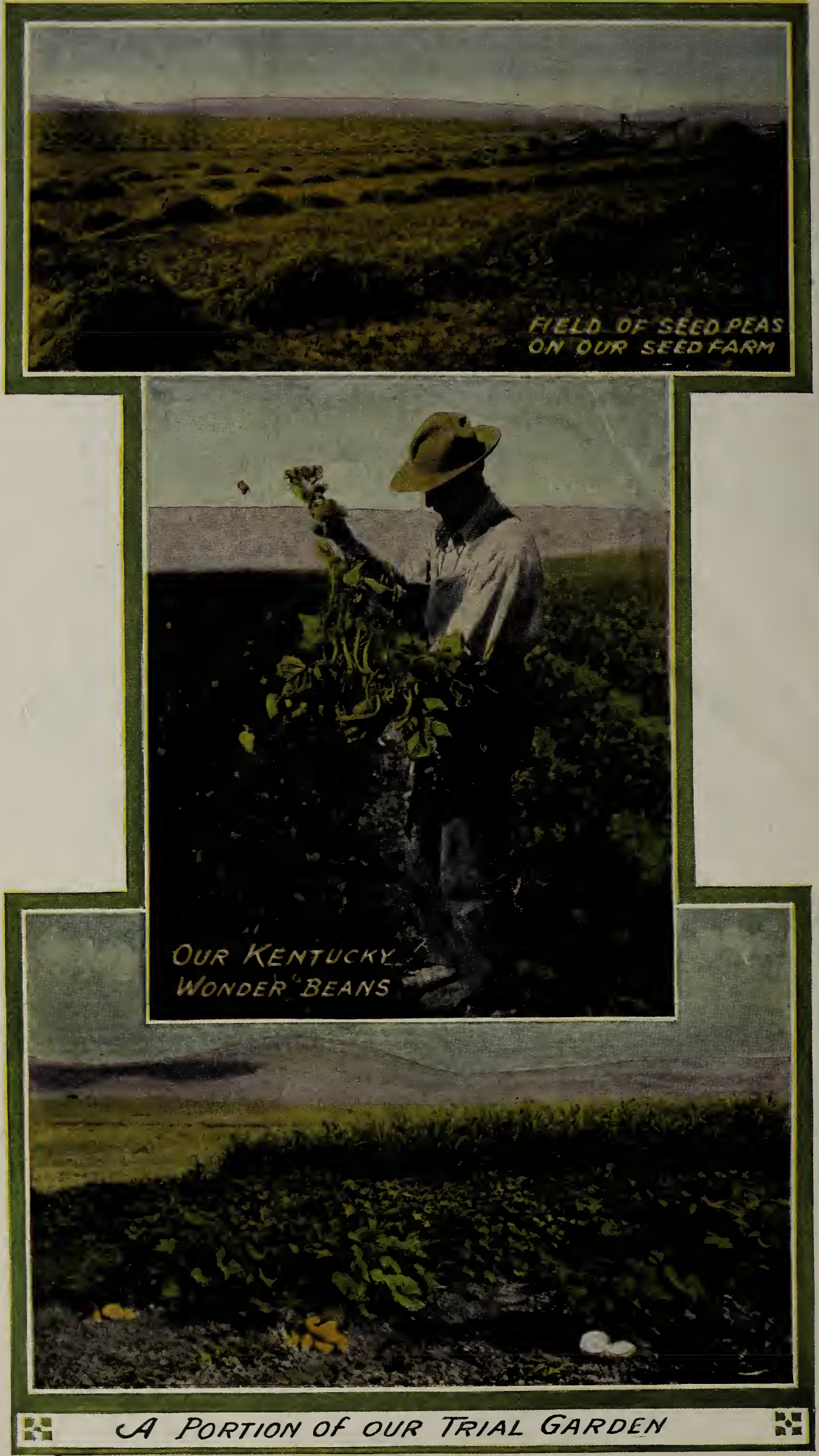

